\author{
Szegedi Tudományegyetem \\ Természettudományi és Informatikai Kar \\ Mikrobiológiai Tanszék
}

Biológia Doktori Iskola

\title{
A polycomb protein RYBP/DEDAF in vivo \\ funkcióinak vizsgálata transzgenikus \\ módszerekkel
}

Ph.D. értekezés

Pirity Melinda Katalin

Témavezető: Dr. Gácser Attila

Szeged 


\section{TARTALOMJEGYZÉK}

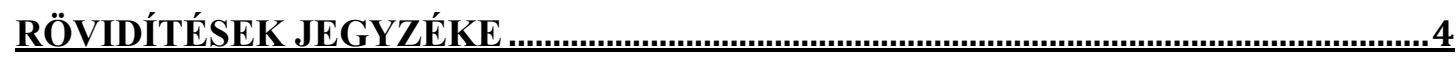

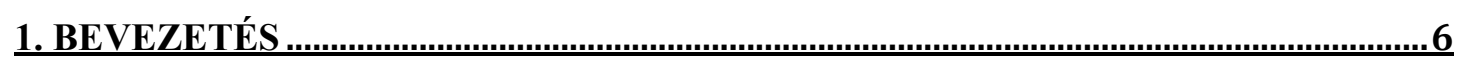

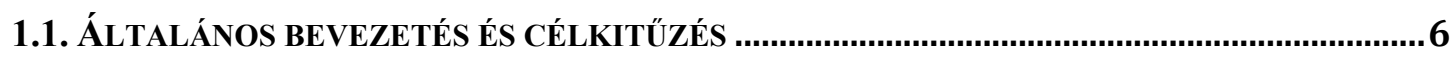

1.1.1. A GÉNEXPRESSZIÓ SZABÁLYOZÁSA ÉS A TRANSZKRIPCIÓS FAKTOROK SZEREPE ........... 6

1.1.2. AZ RYBP FEHÉRJE, MINT TRANSZKRIPCIÓS REGULÁTOR ………………….........................

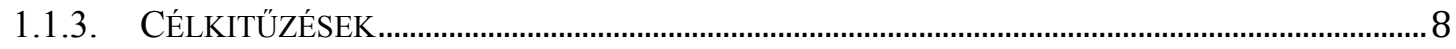

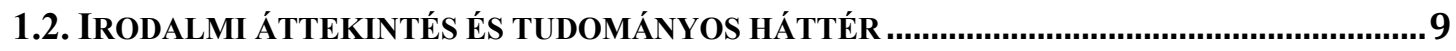

1.2.1. AZ RYBP KÖLCSÖNHATÁSAI EGYÉB ISMERT FEHÉRJÉKKEL..................................................9

1.2.2. AZ RYBP HOMOLÓG YAF2 ÉS FELTÉTELEZETT SZEREPEI: A FUNKCIONÁLIS REDUNDANCIA KÉRDÉSE..

1.2.3. A POLYCOMB CSOPORT PROTEINEK (PCG) ÉS SZEREPÜK A SZABÁLYOZÁSI

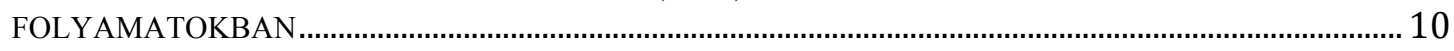

1.2.4. A PRC KOMPLEX TAGOK FENOTÍPUSAI EMLŐSÖKBEN ………............................................ 11

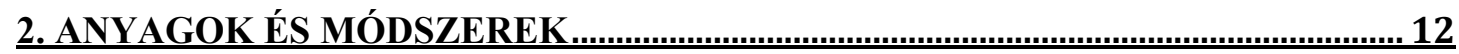

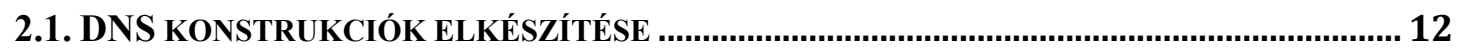

2.1.1. RYBP KNOCK-OUT KONSTRUKCIÓ ELKÉSZÍTÉSE............................................................... 12

2.2.2. RYBP TRANSZGENIKUS VEKTOR-KONSTRUKCIÓ ELKÉSZÍTÉSE.......................................... 13

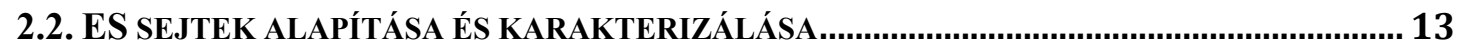

2.2.1. ES SEJTEK TENYÉSZTÉSE .............................................................................................. 13

2.2.2. ES SEJTEK ELEKTROPORÁLÁSA ………………….......................................................... 14

2.2.3. RYBP $^{+/}$ES SEJTEK ALAPÍTÁSA....................................................................................... 14

2.2.4. AZ RYBP-/- ES SEJTEK ALAPÍTÁSA ………………....................................................... 15

2.2.5. ROSA26-RYBP/EGFP TRANSZGENIKUS ES (TG ${ }^{\text {ROSA26-RYBP/EGFP/+ }}$ SEJTEK ALAPÍTÁSA. 16

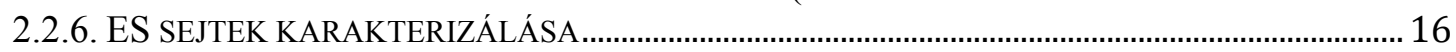

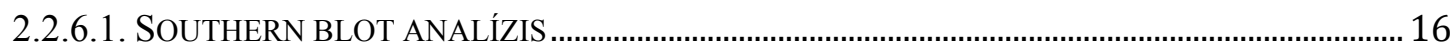

2.2.6.2. PCR ANALÍZIS ................................................................................................................... 17

2.2.6.3. ELEKTROFORÉZIS ÉS IMMUNOBLOT ........................................................................... 17

2.3. RYBP KNOCK OUT ÉS TRANSZGENIKUS EGEREK LÉTREHOZÁSA ÉS ANALÍZISE ........... 18

2.3.1. $\mathrm{RYBP}^{+/-}$EGEREK ELÖÁLLÍTÁSA.................................................................................... 18

2.3.2. A ROSA26-RYBP/EGFP EGÉR $\left(T G^{\text {ROSA26-RYBP/EGFP/+ }}\right)$ ELÖÁLLĹ́TÁSA................................. 19

2.3.3. KIMÉRA EGÉR ELÖÁLLÍTÁSA RYBP ${ }^{-/}$ES SEJTVONALBÓL ................................................... 19

2.3.4. GÉNMÓDOSÍTOTT EGEREK ANALIZÁLÁSA.......................................................................... 19

2.3.4.1. HISZTOLÓGIA ÉS IMMUNHISZTOKÉMIA ………................................................................ 19

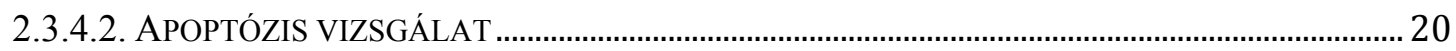

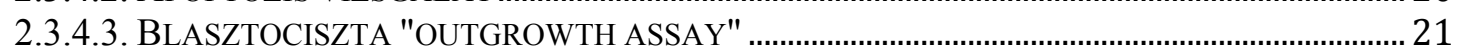

2.3.4.4. ELEKTRONMIKROSZKÓPIA........................................................................................... 22

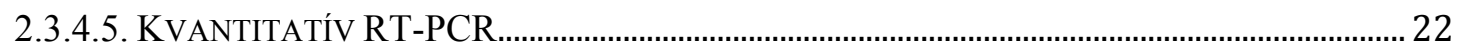

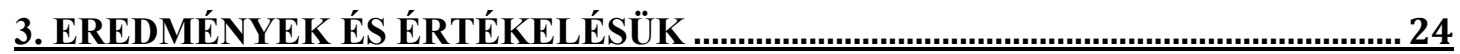

3.1. A RYBP GÉN CÉLZOTT KIKAPCSOLÁSA A KORAI EMBRIÓ ELPUSZTULÁSÁHOZ VEZET24 3.2. PROLIFERÁCIÓS ÉS APOPTOTIKUS DEFEKTUSOK A RYBP NULL HOMOZIGÓTA EGÉR

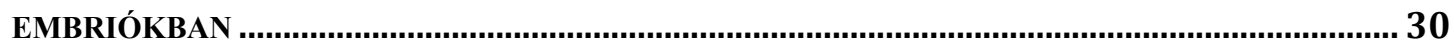

3.3. AZ RYBP EXPRESSZIÓJÁNAK LOKALIZÁCIÓJA A MÉHEN BELÜLI FEJLŐDÉS KORAI

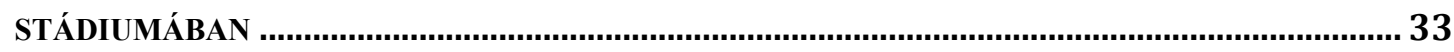


3.4. RYBP SZINTJÉNEK CSÖKKENÉSE BEFOLYÁSOLJA A KÖZPONTI IDEGRENDSZER

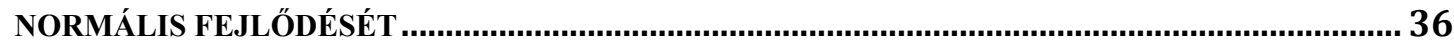

3.5. A RYBP FEHÉRJE IMMUNOLOKALIZÁCIÓJA A FEJLŐDŐ CNS-BEN...............................40

3.6. AZ $R Y B P^{+/}{ }^{2}$ EMBRIÓK EGY RÉSZE SZEM FEJLŐDÉSI RENDELLENESSÉGEKET MUTAT 47

3.7. A $R Y B P^{-/-<->~ R Y B P^{+/+}}$KIMÉRA EMBRIÓK VÁLTOZATOS SZEMFEJLÖDÉSI

RENDELLENESSÉGEKET MUTATNAK ............................................................................. 51

3.8. AZ RYBP TÚLTERMELTETÉSE SZEMLENCSE, RETINA ÉS SZARUHÁRTYA FEJLŐDÉSI

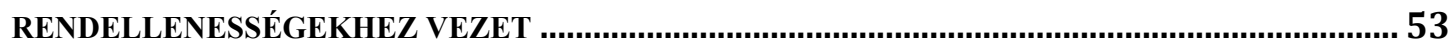

3.9. AZ RYBP TRANSZGENIKUS LENCSÉKBEN BIZONYOS GÉNEK EXPRESSZIÓJA

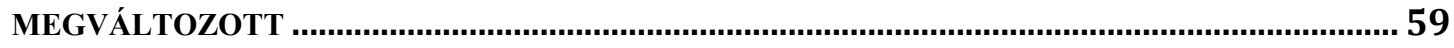

4. AZ EREDMÉNYEK MEGVITATÁSA _.........................................

5. AZ EREDMÉNYEK ÖSSZEFOGLALÁSA_....................................69

6. SUMMARY

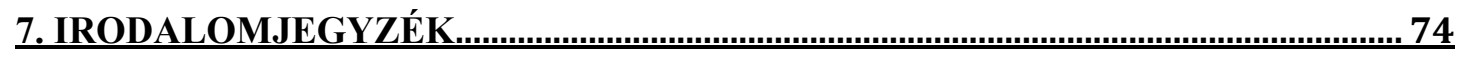

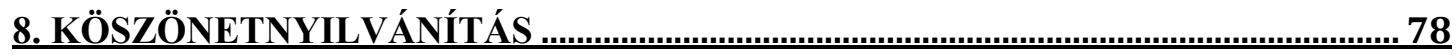




\section{RÖVIDÍTÉSEK JEGYZÉKE}

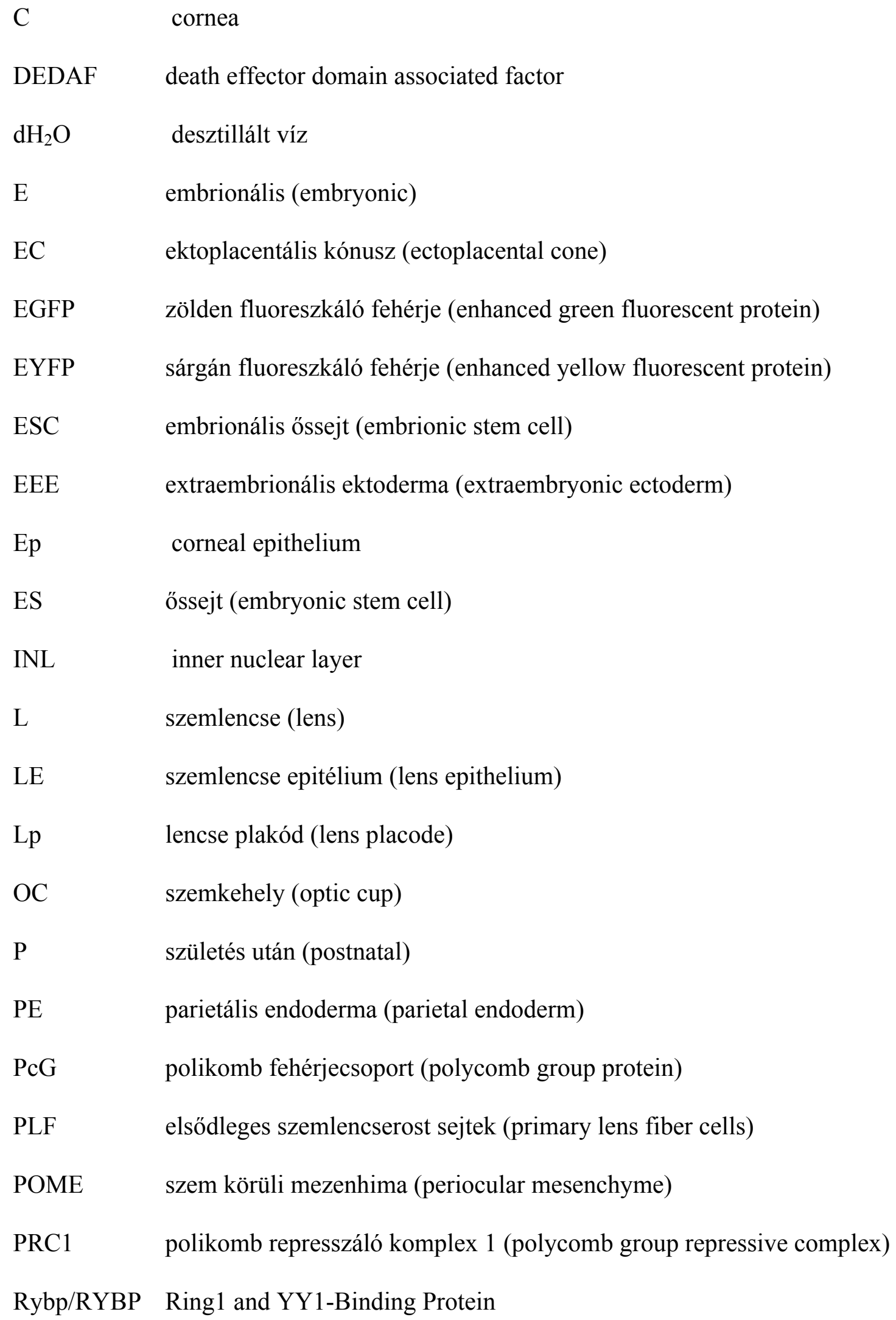


felszíni ektoderma (surface extoderm)

SLF másodlagos lencserost (secondary lens fiber)

TGC trofoblaszt óriássejt (trofoblast giant cell)

GAL4DB GAL4 DNS-kötő domén (GAL4 DNA binding domain)

GCL ganglion cell layer

MEF egér embrionális fibroblaszt (mouse embryonic fibroblast)

NTD velőcső rendellenesség, nyitott velőcső (neural tube defect)

ON $\quad$ szemideg (optic nerve)

ORF nyitott leolvasási keret (open reading frame)

$\mathrm{T} \quad$ tranzíciós zóna (transitional zone)

Tg transzgén

YAF2 YY1 asszociált factor 2 (YY1associated factor 2)

Y2H élesztő két hibrid (yeast two hybrid)

YY1 Ying Yang 1 transzkripciós faktor

VA valporsav (valporic acid)

VE viszcerális endoderma (visceral endoderm) 


\section{BEVEZETÉS}

\section{1. Általános bevezetés és célkitüzés}

\subsubsection{A génexpresszió szabályozása és a transzkripciós faktorok szerepe}

Egy többsejtű élőlény összes sejtje (egyes immun- és ivarsejtek kivételével) ugyanazon genetikai állománnyal rendelkezik. Ennek ellenére a különböző szövetek teljesen eltérő sajátságúak, mert bennük a gének különbözőképpen expresszálódnak, ami különböző funkciók kialakulására ad lehetőséget. Az egyedfejlödés során a transzkripciós faktorok és jelátviteli folyamatok precízen összehangolt hálózata biztosítja a sejtekben zajló összetett folyamatokat úgy mint sejtproliferáció, programozott sejthalál (apoptózis), differenciáció vagy migráció. A sejtek specializációja a gének megfelelő csoportjainak kiválasztásán, expresszióján, illetve annak szabályozásán alapul. A sejtek különböző hatásokra adott válaszai ezeknek a géntermékeknek az összehangolt szabályozásában rejlenek. Valamennyi gén expressziójának elsődleges szabályozása a transzkripciós faktorok által valósul meg, amelyek DNS-szabályozó szekvenciákhoz kötődve indítják el a DNS átírását RNS-sé.

A szabályozó szekvenciák olyan szekvenciaszakaszokat jelentenek, amelyek az átírni kívánt gén előtti szekvenciarégióban, az úgynevezett promóteren illetve a gének intronjaiban helyezkednek el. A promótereken többnyire több szabályozó szekvencia helyezkedik el, és általában több transzkripciós faktor együttes kapcsolódása szükséges az átírás megindításához. A transzkripciós faktorok aktivitása kapcsolatfüggő, és más szomszédos kapcsolódó szabályozó molekulák által is befolyásolt. Ennek megfelelően egy aktivált transzkripciós faktor egy gén 
transzkripcióját indukálhatja, mialatt egy másikét gátolhatja. Így lehetséges, hogy valamennyi gén több jelátviteli folyamathoz kapcsolódik, és átírása finom szabályozási hálózaton keresztül valósul meg $[1,2]$. Az eltérő típusú transzkripciós faktorok bevonása a génregulációba lehetővé teszi a különböző jelátviteli utak összehangolását a sejtmagban [3].

\subsubsection{Az Rybp fehérje, mint transzkripciós regulátor}

Az Rybp fehérjét (Ring1 and YYY1-B̈inding Protein; szintén ismert, mint DEDAF, YEAF1; UniGene Mm.321633; MGI:1929059) elsőként Miguel Vidal munkacsoportja írta le 1999-ben [4]. A munkacsoport a polycomb proteinek szabályozási folyamatokban betöltött szerepét vizsgálja már több mint egy évtizede. Az Rybp fehérjét, mint a Ring1 polycomb fehérje interakciós partnerét izolálták élesztő két hibrid technológia segítségével (yeast two hybrid; Y2H). A feltételezések szerint az újonnan felfedezett Rybp fehérje az emlős polycomb komplex egy új tagjának tekinthető. A Rybp fehérjéről kimutatták, hogy egér embriókban a korai fejlődési stádiumokban mindenütt jelenlevő, általános (ubiquitous) módon expresszálódik és hogy számos, transzkripcióban fontos fehérjével kapcsolatba lép. Így az úgynevezett “moonlighting” fehérjék családjába tartozik, melyekre jellemző hogy egynél több, egymástól eltérő funkciót képesek ellátni [5]. Ennek megfelelően, az Rybp/DEDAF protein - amellett hogy maga is transzkripciós regulátor és polycomb protein - in vitro kölcsönhatásba lép számos, változatos biológiai funkcióval bíró fehérjével, úgymint DNS kötő (YY1), kromatin módosító (Brg1), proapoptotikus (pro-caspase-8), egyéb polycomb (Ring1A, Ring1B, M33, mPC2) vagy például a sejtek proliferációjában és differenciációjában fontos szabályzó funkcióval bíró Myc-Mad-Max hálózat tagjaival (Mxi1). Vidal és munkatársai javasolták, hogy 
az Rybp gén/terméke a transzkripciós szabályozó faktorok közé kerüljön besorolásra, mégpedig azok közé amik a polycomb komplexek tagjaival is kölcsön hatnak. Ezzel egybevágóan a GAL4DNS-kötő domén (GAL4DB)-egér Rybp fúziós protein (GAL4DB-Rybp) valóban transzkripciós represszorként hatott az egér sejteken végzett riporter gén ko-transzfekciós vizsgálatokban [4].

\subsubsection{Célkitüzések}

Jelen disszertáció az egér rybp génnek és termékének, az Rybp proteinnek, in vivo funkcióinak felderítésére szolgáló kísérletsorozatot és azok eredményeit tartalmazza. A disszertáció az egérgenetika transzgenikus eszközeinek alkalmazásával, gén-kiütéssel (KO - knock out ; LOF - loss of function, gén veszítéses/hiányos) és gén túltermeltetéssel (“overexpression” avagy klasszikus transzgenikus; Tg) kívánt rávilágítani az Rybp gén embrionális fejlődésben játszott potenciális szerepére. Ezért munkám során célul tüztem ki a következőket:

(i) Van-e szerepe az Rybp génnek és géntermékének az embrionális fejlődésben?

(ii) Amennyiben nincs szerepe - úgy az $r y b p$ géntermék szerepe redundánsnak tekinthető-e és más fehérjék (pl. homológ YAF2 protein) átvehetik-e a szerepét az embrionális fejlődés során?

(iii) Amennyiben van szerepe (letális fenotípus vagy elváltozások az embrionális fejlődés folyamán), úgy mi a fenotípusa a géndeléciónak és milyen szerveket érint az Rybp gén hiánya az embrionális fejlődésben?

(iv) Összefügg-e a fenotípus az expressziós mintázattal, azaz a fenotípus által érintett szervekben lokalizálódik-e az Rybp fehérje és milyen az expressziós mintázata?

(v) Mi történik ha túltermeltetjük a fehérjét (overexpression) egérben, mely szervek érintettek az embrionális illetve poszt-natális (születés utáni) fejlődésben? 
(vi) Mi lehet a mechanizmus, amivel az Rybp kifejti hatását?

Ezen kérdések megválaszolása segíthet bővíteni, illetve pontosabbá tenni a Polycombés trithorax-csoportba tartozó gének müködéséről kialakított modellünket.

\subsection{Irodalmi áttekintés és tudományos háttér}

\subsubsection{Az Rybp kölcsönhatásai egyéb ismert fehérjékkel}

Az Rybp protein különböző változatos funkciójú fehérjékkel alkotott funkcionális kapcsolatai révén számos fiziológiás és patológiás folyamathoz köthető [6]. Így kölcsönhatásba lép transzkripcionális ko-represszorokkal vagy a sejtproliferációban kulcsfontosságú géntermékekkel. Valójában az Rybp fehérje felfedezése és izolálása a Ring1A (Ring1; a Drosophila ortológja a dRing/Sce/nek) polycomb szabályozó proteinnel való kölcsönhatása révén vált először lehetővé [4]. Később kimutatták, hogy az Rybp a Ring1B-vel (Ring2/Rnf2; Drosophila dRing/Sce orthológ) és a M33-mal (Pc1 Drosophila Pc orthológ) is kölcsönhat [4]. Ez a három PcG protein a gének stabil represszált állapotáért felelős, a PRC1 PcG multiprotein komplex tagjaiként is ismertek.

Más tanulmányok kimutatták hogy az Rybp fehérje kölcsönhat számos egyéb transzkripciós faktorral is, így például a DNS kötő E2F család tagjaival [7], valamint a proto-onkogén myc szabályozott ("responsive") génekkel [8]. Az Rybp és Myc (Nés C-myc) kapcsolat egyben a sejtciklus szabályozásban betöltött potenciális szerepkörre is utal, hiszen a myc géncsalád tagjainak a sejtciklus szabályozásában bizonyítottan fontos és meghatározó szerepe van. Az Rybp gén kulcsfontosságú szerepét támasztja alá az a megfigyelés is, hogy valószínűleg E2F és YY1 kötőhelyek

között létesít kapcsolatot és mintegy „áthidaló” feladatot lát el a specificitást 
biztosítva [7].

\subsubsection{Az Rybp homológ Yaf2 és feltételezett szerepei: a funkcionális redundancia kérdése}

A Yaf2 fehérjét 1997-ben írták le először, mint a DNS kötő YY1 transzkripciós faktorral kölcsönható cink-finger proteint [9], amelyet az Rybp fehérjéhez hasonlóan élesztő két hibrid technológia segítségével azonosították. A Yaf2 fehérjéröl, ami aminosav szinten 55\%-ban homológ az Rybp-vel, szintén kimutatták hogy kölcsönhatásba lép számos PRC1 komplex taggal és DNS kötő fehérjével [6, 9, 10]. Egy korai modell szerint az Rybp transzkripcionális ko-represszorként, míg a Yaf2 ko-aktivátorként funkcionál $[4,6,9]$, noha későbbi tanulmányok kimutatták ennek az ellenkezőjét is $[7,11]$. A két fejérje domén szerkezete is hasonló: azok N-terminális régiót kivéve, ahol a cink-finger domének találhatók, egy szerin-gazdag rész húzódik amely nem mutat homológiát más ismert fehérje doménekkel és nagyfokú rendezetlenséget muatat (IDP; intrinsically disordered proteins) [4, 5, 9].

\subsubsection{A polycomb csoport proteinek (PcG) és szerepük a szabályozási folyamatokban}

A polycomb csoport proteineket (PcGs) az ecetmuslicában (Drosophila melanogaster) írták le először. Multimer komplexeket alkotnak (PcG bodies), amelyek a génexpresszió stabil represszálásában játszanak alapvető szerepet így a kromatin remodellező epigenetikus szabalyozógének családjába is besorolást nyertek. A PcGs csoportjába tartozó fehérjék a cisz-regulátorok inaktív állapotának (zárt kromatin-konformációjának) fenntartásáért felelősek, míg a TRITHORAX-csoport (TRXG) tagjai az aktív cisz-regulátorok (nyílt kromatin-konformációjú) állapotát tartják fenn. Ez a két komplex egymással ellentétesen dolgozik, míg a PcG fehérjék 
represszálnak addig a TRXG fehérjei aktiválnak. Target génjeik az úgynevezett homeotikus gének, amelyek olyan konzervált mestergének (transzkripciós regulátorok), melyek az egyedfejlődés során korán bekapcsolnak és mindvégig aktívak maradnak. A PcG és TRXG csoport tagjai egymással genetikai kölcsönhatást mutatnak: azonos csoportba eső gének mutációi egymás fenotípusát általában erősítik, míg az ellentétes hatású gének mutációi gyengítik egymást. A POLYCOMB, illetve TRITHORAX-csoportba tartozó fehérjék a homeotikus gének cisz-regulátoraiban található PRE- (Polycomb Response Element), illetve TRE-szakaszokon (TRE: Trithorax Response Element) keresztül szabályoznak. Expressziójuk szelvényspecifikus, szerepük, hogy az általuk szabályozott végrehajtó géneken keresztül kialakítsák az adott szelvény identitását. Mind a TRXG, mind pedig a PcG fehérjék nagyfokú evolúciós konzervativizmust mutatnak a férgektől egészen a magasabb rendü gerincesekig, ami müködési mechanizmusuk konzervatív jellegére utal és egyben rámutat evolúciós fontosságukra is [12].

\subsubsection{A PRC komplex tagok fenotípusai emlősökben}

Emlősökben a PcG fehérjék számos fontos fejlődésbiológiai szereppel bírnak. Így például az egér PRC2 komplex tagjainak mutációi embrionális letális fenotípust okoznak, míg a PRC1 komplex tagok müködésének a felfüggesztése homeotikus transzformációkat mutató peri-natális (születés körüli) fenotípust okozott [14]. Ezzel ellentétben a PcG komplex tagjainak túltermeltetése bizonyos rákos folyamatok áttételekre való hajlamának (“invasiveness”) és rossz indulatának (“malignancy”) az egyik fokmérője. Sőt, a Drosophila PRC1 komplexek nagyon hasonlóak az emlős PRC1 komplexhez ami például a rákos folyamatok szabályozásában kiemelkedő szereppel bíró ink4 (P16, P19ARF) lókuszt is szabályozza [13]. 


\section{ANYAGOK ÉS MÓDSZEREK}

\subsection{DNS konstrukciók elkészítése}

\subsubsection{Rybp knock-out konstrukció elkészítése}

Az Rybp eltávolítását célzó (gene targeting) vektor elkészítéséhez először génkönyvtárból ki kellett nyernünk az Rybp genomikus szekvenciáját. Ehhez az egér Rybp cDNS szekvenciájával hibridizáltunk a 129/SvJ hátterü egér genom-könyvtárra. Először egy 18 kb méretű genomikus részt (klónt) azonosítottunk, amely tartalmazta a Rybp gén 3-4-5-ös exonjait (pRYBP18). Az így azonosított genomikus szakaszt pBluescript $\mathrm{SK}(+)$ plazmidba klónoztuk be. Az így elkészített pRYBP18 fragmentumot szekvenáltuk és a szekvencia alapján megállapítottuk ennek a szakasznak az exon-intron határait és azonosítottuk a restrikciós hasító helyeit.

A vektor elkészítéséhez egy 5 kb DNS szakaszt, ami az Rybp gén 3., 4. és 5. exonjait tartalmazta kicseréltük egy sárga fluoreszcens riporter fehérjére (enhanced yellow fluorescent protein (EYFP), és egy loxP szekvenciákkal körülvett PGKneo kazettára. Az így elkészített konstrukció 5' végére 0,75 kb hosszúságú, a 3' végére pedig 5,25 kb hosszúságú homológ genomikus régiót klónoztunk.

Az 5' homológ régiót a pRYBP18 genomikus szakaszából nyertük PCR reakcióval (primer A, 5'-GTTAAGCTTACGCGTTGTGCAGAAATATTG-3'， és primer B, 5'-GTTAAGCTTCGATGCGAGGTTTCCTACAAC-3'). A PCR terméket ezután EYFP (Clontech)-floxed neo vektorba klónoztuk. A 3' homológ régió elkészítéséhez, HindIII enzimmel kivágtunk a Rybp gén nem átíródó régiójából egy 5,25 kb hosszúságú szakaszt, amelyet a floxed pGK-Neo kazetta 3' végén elhelyezkedő SacII helyre klónoztunk be. A targetáló vektort Mlu1 enzimmel (melyet 
primerA-val vittünk be) linearizáltuk és R1 ES (embryonic stem) sejtekbe elektroporáltuk.

\subsubsection{Rybp transzgenikus vektor-konstrukció elkészítése}

A ROSA26-RYBP/EGFP transzgenikus egér előállításához egy olyan vektor konstrukciót készítettünk, amely a RYBP/EGFP fúziós fehérje szekvenciája előtt tartalmazott egy LoxP szekvenciákkal körülvett neomicin kazettát (floxedNeo) és a ROSA26 targetálásához szükséges szekvenciákat [15].

A konstrukció elkészítéséhez az Rybp fehérjét kódoló szekvenciát PCR reakcióval szaporítottuk fel a következő primerekkel: primer A (5'gcacgtcgaccagccegtccatgaccatgg) és primer B (5'-ctctggatccgaaagattcatcattcactgc). Az így elöállított DNS szakaszt NheI/SalI restrikciós enzimekkel történt emésztés után ligáltuk a $p E G F P-\mathrm{N} 3$ plazmidba. Az RYBP/EGFP fúziós fehérjét NheI/NotI enzimekkel átklónoztuk a pBigT [16] plazmidba, amely a floxedNeo kazettát tartalmazta. Ezután az így létrehozott floxedNeo-RYBP/EGFP kazettát átklónoztuk a p26ROSA plazmidba, AscI/PacI restrikciós enzimekkel [16].

\subsection{ES sejtek alapítása és karakterizálása}

\subsubsection{ES sejtek tenyésztése}

A sejtek tenyésztését Nagy és munkatársai módszerét követve végeztük az alábbiak szerint [17]. Az ES sejtek differenciálatlan állapotban való fenntartásához mitomicin C antibiotikum kezelt (Sigma, $10 \mu \mathrm{g} / \mathrm{ml}$ ), 13,5 napos egér embrió kötőszövetes részeiből származó egér embrionális fibroblaszt (mouse embrionic fibroblast; MEF) tápláló sejtréteget használtunk. A sejteket ES médiumban 
tenyésztettük DMEM (Gibco) és 15\% FCS kiegészítés mellett (Hyclone). A tápoldat L-glutamin (Gibco; 2 mM), ß-merkaptoetanol (Sigma; 0,1 mM), Na-piruvát (Gibco, $1 \mathrm{mM}$ ) nem esszenciális aminosav (Sigma, $10 \mathrm{mM}$ ), penicillin (Gibco, $50 \mathrm{U} / \mathrm{ml}$ ), streptomycin (Gibco, $50 \mu \mathrm{g} / \mathrm{ml}$ ) és rekombináns egér Leukémia Inhibitor Faktor (ESGRO-LIF; Chemicon; $1000 \mathrm{IU} / \mathrm{ml}$ ) kiegészítést tartalmazott. A sejteket kétnaponta passzáltuk Tripszin:EDTA (0,05\% tripszin; Gibco) emésztést végezve új mitomicin C kezelt fibroblaszt sejtrétegre az optimális sejtszám beállítását követően.

\subsubsection{ES sejtek elektroporálása}

Az elektroporáláshoz az egér őssejteket a fent említett módon tripszineztük, majd centrifugálás után PBS-ben mostuk és szintén ülepítettük. A sejtpelletet ezután

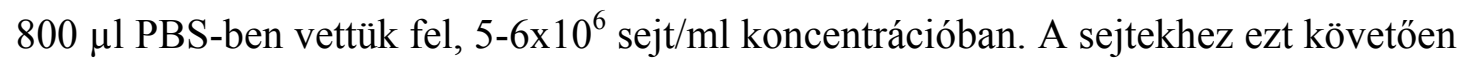

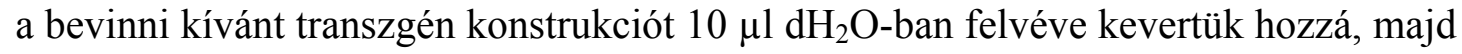
azonnal elektroporátor küvettába helyeztük és elektroporáltuk (BioRad).

\subsection{3. $R y b p^{+/-}$ES sejtek alapítása}

A linearizált targetáló vektort R1 ES sejtekbe elektroporáltuk standard protokoll szerint. Ezt követően a sejteket tenyésztő médiummal tízszeres térfogatra hígítottuk, majd mitomicin $\mathrm{C}$ kezelt neomicin rezisztens $\mathrm{MEF}$ tápláló sejtréteget tartalmazó, 10 cm-es Petri-csészékre szélesztettük.

Az antibiotikum szelekciót 24-48 óra múlva kezdtük meg (300 $\mu \mathrm{g} / \mathrm{ml}$ G418). A klónok szelektálása 10 nap elteltével kezdődött.

A szelektált klónokat sztereómikroszkóp alatt (SZH, Olympus) mikropipetta segítségével helyeztük át egyedileg, 96-lyukú tenyésztőedénybe. A klónok felnövekedését követően a tenyészet egy részét analízis céljából félretettük, a maradék 
sejteket pedig lefagyasztottuk. A klónok analízisét a megfelelő technikával (PCR vagy Southern blot) a targetált szekvencia alapján tervezett primerekkel és próbákkal végeztük. A jól targetált klónokat visszavettük fagyasztásból és 24-lyukú tenyésztőedényben, végül pedig $6 \mathrm{~cm}$-es Petri-csészében tenyésztettük tovább, a szokásos ES-tenyésztési protokollt követve.

\subsubsection{Az rybp-/- ES sejtek alapítása}

A $r y b p^{-/}$ES sejteket az $r y b p^{+/}$ES sejtekből hoztuk létre a vad típusú allél újabb targetálásával. Ehhez elöször a $r y b p^{+/-}$ES sejtekből Cre rekombináz segítségével eltávolítottuk a PGKneo kazettát. Az ES sejteket $25 \mu \mathrm{g}$ cytomegalovírusCre-rekombináz (pBS185) [18] expressziós plazmiddal elektroporáltuk. Két nappal az elektroporáció után a sejteket $10 \mathrm{~cm}$-es zselatinnal fedett sejttenyésztő edényekbe tettük, $5 \times 10^{3}$ sejt/ml koncentrációban. A sejtek 5 nap múlva jól körülhatárolható, egyedülálló kolóniákat képeztek, melyeket kiszedtünk és felszaporítottunk. Az így keletkezett sejtvonalakban teszteltük, hogy tartalmazzák-e még a PGKneo kazettát. A PGKneo kazetta jelenlétét PCR-rel és a klónok G418 érzékenységének meghatározásával (200 ㅆg/ml 7-9 nap; Gibco) mutattuk ki. A következő primereket használtuk a PGKneo kazetta kimutatására: primer A, 5'AGAGGCTATTCGGCTATGACTG-3', és primer B, 5'CCTGATCGACAAGACCGGCTTC-3'. A PCR reakcióhoz pozitív kontrollnak az mxil génre specifikus primereket használtuk (primer A, 5'CTGGTGTTTCTTCTGGCTTCC-3', ${ }^{\prime}$ és primer $\mathrm{B}, \quad 5^{\prime}$ GGGGCTCGGCATGGAGGGGAA-3'). Azokat a klónokat, amelyek nem tartalmazták a PGKneo kazettát újabb elektroporációnak vetettük alá, amelyet ismét az eredeti targetáló vektorral végeztünk. Ezt követően a sejteket mitomicin C kezelt 
neomicin rezisztens MEF tápláló sejtréteget tartalmazó, $10 \mathrm{~cm}$-es Petri-csészékre szélesztettük. A szélesztést követő napon a sejteket $200 \mu \mathrm{g} / \mathrm{ml}$ G418-tal szelektáltuk 10 napon keresztül. Ezt követően a klónokat kiszedtük és felszaporítottuk további tesztelésre.

\subsubsection{ROSA26-RYBP/EGFP transzgenikus ES (Tg ${ }^{\text {ROSA26-RYBP/EGFP/+ }}$ sejtek alapítása}

Rybp transzgenikus ES sejtvonal létrehozásához a floxedNeo-RYBP/EGFP kazettát tartalmazó ROSA26 targetáló konstrukcióval R1 ES sejtvonalat elektroporáltunk, majd G418-cal (GIBCO, $300 \mu \mathrm{g} / \mathrm{ml}$ ) szelektáltuk (ld. 2.3 pont). A klónokat DNS-DNS hibridizációval vizsgáltuk a transzgén jelenlétére [16].

\subsubsection{ES sejtek karakterizálása}

\subsubsection{Southern blot analízis}

$\mathrm{Az}$ analízishez a genomikus DNS-t $X b a \mathrm{I}$ enzimmel emésztettük, majd a fragmentumokat gélelektroforézissel szétválasztottuk. Ezután nylon membránra blottoltuk és $\left[\alpha-{ }^{32} \mathrm{P}\right] \mathrm{dCTP}$ izotóppal jelölt próbával hibridizáltuk. A próba az Rybp gén 2. intronjának egy $0,35 \mathrm{~kb}$ régióját tartalmazta, melyet a pRYBP18 fragmentumból PCR reakcióval nyertünk (primer A 5'CAAACCCTATCTCGGGTTGCA-3', $\quad$ primer $\quad$ B GGGTACAATGCGAGGACAGTT-3'). Ez a próba $X b a \mathrm{I}$ emésztés után egy 8 kb-os szakaszt ismert föl a vad típusú allélt tartalmazó, és egy 5 kb-os szakaszt a targetált klónokban. 


\subsubsection{PCR analízis}

Genomikus PCR reakciót az Rybp 2. intronra tervezett primerrel (5'TATGGCTACACGATATGGGCT-3') és az EGFP-N (Clontech) szekvenáló primerrel végeztük a következő körülmények között: denaturálás $-94^{\circ} \mathrm{C} 40 \mathrm{~s}$, primer feltapadás $-60^{\circ} \mathrm{C} 30 \mathrm{~s}$, és lánchosszabbítás $-72^{\circ} \mathrm{C} 120 \mathrm{~s}, 33$ cikluson keresztül. A PCR reakció 800 bázis hosszúságú fragmentumot eredményezett a jól targetált klónokból.

\subsubsection{Elektroforézis és immunoblot}

Az ES sejteket feltárás előtt PBS-sel mostuk és jégen tartottuk. A feltárást jégben előhütött feltáró oldattal végeztük proteáz inhibítor koktél jelenlétében $(1 \%$ NP-40, 1\% deoxycholic acid, $0,1 \%$ sodium dodecyl sulfate, $150 \mathrm{mM} \mathrm{NaCl}, 10 \mathrm{mM}$ sodium phosphate [pH 7,2], $2 \mathrm{mM}$ EDTA és $50 \mathrm{mM}$ Tris-HCl). A $10 \mu \mathrm{g}$ fehérjét tartalmazó lizátumot 7,5 ill. 10\%-os SDS-poliakrilamid gélen választottuk el MiniProtean elektroforézis készüléket (Bio Rad) használva. A gyüjtögélben állandó 25 mA, míg a szeparálógélben $35 \mathrm{~mA}$ áramerősség mellett ELFO pufferben $(25 \mathrm{mM}$ Tris-OH, pH 7,7; 0,7 M glicin; 0,1\% SDS), 1,5-2 óra alatt választottuk el a mintákat.

Ezután a fehérjéket 0,2 pm pórusméretü PVDF (Bio-Rad) membránra blottoltuk át a Mini-Trans-Blot (Bio-Rad) készülék segítségével, transzfer pufferben (25 mM Tris, pH 8,3; $25 \mathrm{mM}$ glicin; 20\% metanol), $200 \mathrm{~mA}$ áramerősségen, 60 percen át, jéghütés mellett. A PVDF membránt ezután 5\% (g/v) tejet (Carnation nonfat dry milk) tartalmazó TBS-TWEEN pufferben (50 mM pH 7,4 Tris, $200 \mathrm{mM}$ $\mathrm{NaCl}$ és $0,1 \%(\mathrm{v} / \mathrm{v})$ Tween 20) áztattuk egy órán át. A membránokat egy éjszakán keresztül inkubáltuk elsődleges ellenanyaggal; anti-RYBP (anti-DEDAF; 1:1,000, Chemicon AB3637), anti-Max (1:1,000, Santa Cruz SC-197) vagy anti-GFP (1:1,000, 
Molecular Probes).

Másodlagos ellenanyagként anti-nyúl, tormaperoxidázzal konjugált 50000szer hígított antitestet alkalmaztunk (NA934V; Amersham). A specifikusan nem kötődött másodlagos antitestet mosással távolítottuk el (háromszor 20 perc, $0,1 \%$ TBS-TWEEN), majd a peroxidáz-függő lumineszcenciát „enhanced chemiluminescence" technikával (ECL, Amersham), autoradiográfiával határoztuk meg.

\subsection{Rybp knock out és transzgenikus egerek létrehozása és analízise}

\subsubsection{Rybp $^{+/-}$egerek előállítása}

A knock out egerek létrehozásához három megfelelő módon, homológ targetált ES sejtvonalat használtunk (A6, F4 és G3). Hólyagcsíra stádiumú egér embrióba injektáltuk a targetált ES sejteket standard protokoll szerint. Az így létrehozott hím kimérákat fehér színszőrü IRC (elnevezését az „Institute for Cancer Research” származási helyéről még 1948-ban kapta) vagy CD1 (elnevezését a „CD1” molekula hiányáról kapta) genetikai hátterü nőstény egerekkel pároztattuk és az aguti színü utódaikat teszteltük, hogy tartalmazzák-e a targetált allélt. A mutáció jelenlétét egér farokból izolált DNS-ből YFP-re specifikus PCR primerekkel mutattuk ki (primer A, 5'-AAGTTCATCTGCACCACCG-3', és primer B, 5'TGCTCAGGTAGTGGTTGTCG-3'). A targetált allélt heterozigóta formában hordozó egereket párosítottuk, és több mint 1000 utódot analizáltunk a három sejtvonalból. Mindhárom sejtvonalból származó egerek ugyanazt a fenotípust mutatták. 


\subsubsection{A ROSA26-RYBP/EGFP egér $\left(T_{g^{R O S A 26-R Y B P / E G F P /+}}\right)$ előállítása}

Kettő jól targetált klónt C57BL/6 egérből származó hólyagcsíra állapotú embrióba injektáltunk. Az injektálással elóállított ivarsejt kimérákat (ROSA26RYBP/EGFP egér), PCR-rel genotipizáltuk [16]. A hím kimérákat ICR genetikai hátterü nőstényekkel kereszteztük, majd az aguti színű utódaikat teszteltük a transzgén jelenlétére. A mutációra heterozigóta állatokat Cre transzgenikus egerekkel kereszteztük és az így létrehozott egereknek analizáltuk a fenotípusát. A nem transzgenikus alomtársaikat kontrollként használtuk a kísérleteinkben. A heterozigóta transzgenikus utódokat pároztattuk, hogy fenntartsuk a mutáns allélt. Mindegyik analízist kevert (129 x ICR) hátterü egereken végeztük.

\subsubsection{Kiméra egér előállítása $r y b p^{-/-}$ES sejtvonalból}

Kiméra embriók előállításához rybp ${ }^{-/-}$R1 (129/Svx129-Cp hátterü) ES sejteket injektáltunk vad típusú, 129/Svx129-Cp hátterü egerekből származó hólyagcsíra állapotú embriókba. Az embriókat ezután visszaültettük anya egerek méhébe. A kiméra embriókat különböző fejlődési stádiumokban vizsgáltuk fluoreszcens sztereómikroszkóppal. Az embriókról fényképeket készítettünk, majd hisztológiával analizáltuk.

\subsubsection{Génmódosított egerek analizálása}

\subsubsection{Hisztológia és immunhisztokémia}

Az embriókat 4\% paraformaldehid tartalmú PBS-ben fixáltuk egy éjszakán keresztül. Fixálás után az embriókat metanol grádienssel víztelenítettük, majd paraffinba ágyaztuk. A paraffinba beágyazott embriókból 4-6 $\mu$ m-es szekciókat 
(,serial sections” vagy sorozatos metszetek) vágtunk. Immunhisztokémiai analízishez az így elkészített szekciókból eltávolítottuk a paraffint, majd re-hidratáltuk. A rehidratált szekciókat 3\% $\mathrm{H}_{2} \mathrm{O}_{2}$ oldattal kezeltük, hogy ezzel eltávolítsuk az endogén peroxidázokat. Ezután a hidrogénperoxidot vizes, majd PBS-es mosással eltávolítottuk és 10\% BSA tartalmú PBS-sel blokkoltuk a szekciókat. Blokkolás után a szekciókat elsődleges ellenanyaggal egy éjszakán át inkubáltuk. Az ellenanyagok a következők voltak: anti-phospho-hiszton H3 (Ser 10), clone RR002 (egér monoklonális, 1:1,000; Upstate 05-598MG) Pax2 (hígítás 1:200, Babco, PRB276P, nyúl), Pax6 (hígítás 1:500, egér IgG1, DSHB), Nestin (hígítás: 1:100, egér IgG1, DSHB Rat-401), NeuN (hígítás: 1:1000, Chemicon MAB377), TUJ1 (hígítás: 1:2000, Sigma T8660), anti-RYBP (nyúl anti-DEDAF poliklonális, 1:100; Chemicon AB3637).

A felesleges elsődleges ellenanyag eltávolítása után a mintákat anti-egér vagy anti-nyúl 400x-os hígítású biotinnal konjugált másodlagos ellenanyaggal inkubáltuk szobahőmérsékleten 45 percig (Vector laboratórium). Ezután 45 percig biotináltavidin enzim komplex-szel inkubáltuk a szekciókat és végül DAB kittel (Vector laboratórium) hívtuk elő a színreakciót.

\subsubsection{Apoptózis vizsgálat}

Apoptózis kimutatásához embriókban úgynevezett terminál deoxynucleotidyltransferase-mediated dUTP-biotin nick end labeling (TUNEL) analízist alkalmaztunk. Az embriókat egy éjszakán át 4\% paraformaldehiddel fixáltuk, majd felszálló metanol gradienssel víztelenítettük és paraffinba ágyaztuk. A paraffinba beágyazott szövetekböl $6 \mu \mathrm{m}$ vastag metszeteket készítettünk. Az így elkészített szekciókat előinkubáltuk 0,1\% Triton X-100-at tartalmazó 1x One-Phor- 
All (OPA) pufferben (Pharmacia Biotech). Ezután a mintákat $100 \mu$ l hibridizáló oldatba tettük, amely 1x OPA puffert, $6 \mu \mathrm{M}$ dATP-t, $3 \mu \mathrm{M}$ biotin-UTP-t (Sigma), $1 \mu \mathrm{l}$ terminális transzferázt (TdT; Pharmacia), 0,1\% Triton X-100-at tartalmazott és egy óráig $37^{\circ} \mathrm{C}$-on inkubáltuk. Ezután PBS-sel mostuk, majd Texas Red-del konjugált sztreptavidinnel (1:150 dilution; Calbiochem) inkubáltuk $4^{\circ} \mathrm{C}$-on 30 percig. Inkubálás után a metszeteket 3x mostuk PBS-ben, majd az utolsó mosáshoz 4',6'-diamidino-2phenylindole-t (DAPI) adtunk és lefedtük. A mintákat Axiovert 200M mikroszkóppal analizáltuk.

\subsubsection{Blasztociszta "outgrowth assay"}

Rybp +/- egerek keresztezéséből származó 3,5 napos hólyagcsíra állapotú embriókat izoláltunk. Négy különböző egérböl származó almot analizáltunk. A hólyagcsíra állapotú embriókat ES médiumot tartalmazó, zselatinnal (Sigma) fedett 12-lyukú tenyésztő edényekbe tettük. A kihelyezést követően 4 napon át fényképeket készítettünk az embriókról. A hólyagcsíra állapotú embriók általában 48 órával a kihelyezés után tapadnak le, majd trophektodermális jellegü kinövéseket formálnak.

A genotipizáláshoz mindegyik embrióból mintát vettünk, majd $2 \mu$ lízis pufferrel lizáltuk ( $5 \mathrm{mM}$ dithiothreitol, 0,8\% Igepal CA630, es $900 \mu \mathrm{g} / \mathrm{ml}$ proteináz $\mathrm{K}$ kétszer desztillált vízben). A mintákat $65^{\circ} \mathrm{C}$-on melegítettük 15 percig majd $94^{\circ} \mathrm{C}$-on 15 percig a PCR reakció előtt. PCR reakcióhoz a következő körülményeket használtuk: $95^{\circ} \mathrm{C} 12$ perc; 35 ciklus: $94^{\circ} \mathrm{C} 1$ perc, $60^{\circ} \mathrm{C} 1$ perc, $72^{\circ} \mathrm{C} 2$ perc; végül $72^{\circ} \mathrm{C} 7$ perc. A következő primereket használtuk: Rybp 3'UTR PCR (nincs jelen az Rybp-/- embriókban) - primer A, 5'-GCGACATGTCAGCAGTGAATG-3', és primer B, 5'-GTGTCAAGAATAACTGTCAGGG-3'; Rybp 5' UTR PCR (kontroll reakció):

primer A, 5'-CAAACCCTATCTCGGGTTGCA-3', primer B, 5'- 
GGGTACAATGCGAGGACAGTT-3'. A PCR terméket (220bp - 3' UTR reakció és 400 bp - the 5' UTR reakció) gélelektroforézissel analizáltuk. A nullembriók negatív reakciót adtak a 3' UTR reakcióban, de képeztek terméket az 5' UTR reakcióban.

\subsubsection{Elektronmikroszkópia}

Az elektronmikroszkópiás vizsgálathoz P1 és P21 napos szemeket izoláltunk, melyeket a szaruhártyájuknál egy finom hegyü tűvel kilyukasztottunk, majd 24 óráig Ito’s fixaló oldatba tettünk. A szemeket ezután egy éjszakán át cacodylate pufferben mostuk, majd $\mathrm{OsO}_{4}$-dal utófixáltuk. Ezután dehidratáltuk és beágyaztuk Epon gyantába (Roth, Karlsruhe, Germany). Az így elkészített mintákból félig vékony és ultra-vékony metszeteket készítettünk. A félig-vékony szekciókat toluidin kékkel, az ultra-vékony szekciókat pedig uranil-acetáttal és ólom-citráttal festettük, majd Zeiss (Oberkochen, Germany) EM 902 elektronmikroszkóppal analizáltuk.

\subsubsection{Kvantitatív RT-PCR}

A kvantitatív PCR reakcióhoz P1 és P21 napos $T G^{R O S A 26-R y b p / E G F P /+}$ (heterozigóta) vagy $T G^{R O S A 26-R y b p / E G F P / R O S A 26-R y b p / E G F P} \quad$ (homozigóta); $\quad \alpha \mathrm{A}$-crystallin/Cre egerek retinájából és szemlencséjéből totál RNS-t izoláltunk, és cDNS-t készítettünk. A PCR reakcióhoz a következő primereket használtuk: Pax6 A, (5'-gcacatgcaaacacacatga) és B, (5'-acttggacgggaactgacac); Prox1 A, (5'-gccctcaacatgcactacaa) és B, (5'ggcattgaaaaactcccgta); MafA A, (5'-gcacccgacttctttctgtg) és B, (5'gcctgcgcaaacttgtcc); MafB A, (5'-gcctcttagacttgggcaga) és B, (5'cettccagcttggagaaaag); c-Maf A, (5'-gtggtggtgatggctctttt) és $\mathrm{B}, \quad\left(5^{\prime}-\right.$ gttacgggggaattcaggtt); Rybp A, (5'-agaccagcgaaacaaaccac-3') és B, (5'aggaggagcgagtcttttcc-3'); Crystallin $\beta A 4$ (Cryba4) A, (5'-gggtttgttcccagttcct-3') és B, 
(5'-acctgagtggtgatcgctct-3'); Filensin (Bfsp1): A, (5'-cattgagattgaaggcagca-3') és B, (5'-acactggatccaaggctgag-3'); AP2 $\alpha \quad$ A, (5'-gtgtcagagatgctgcggta-3') és B (5'tgaggatggtgtccacgta-3'); Integrin $\alpha-6 \quad \mathrm{~A}, \quad$ (5'-attctcctgagggcttccat-3') és $\mathrm{B}, \quad$ (5'ttgagggaaacaccgtcact-3'); Sox2 A, (5'-acttttgtccgagaccgaga-3') és B, (5'ctccggcaagcgtgtactta-3'); és B2M A, (5'-catacgcctgcagagttaagc-3') és B, (5'gatgcttgatcacatgtctcg-3'). A PCR reakciót 7900 HP Applied Biosystems Real Time PCR készülékkel végeztük. 


\section{EREDMÉNYEK ÉS ÉRTÉKELÉSÜK}

\subsection{A rybp gén célzott kikapcsolása a korai embrió elpusztulásához vezet}

Hogy megvizsgáljuk az egér rybp gén fejlődésben játszott szerepét, egy mutáns allélt generáltunk gén targetált ES sejtek segítségével, amelyet aztán bevittünk egér csírasejtvonalba (germline). Röviden: az egér rybp gén lokuszát tartalmazó genomiális klónokat jellemeztük és kimutattuk, hogy hordozzák a 3-5 exonokat (1a ábra).

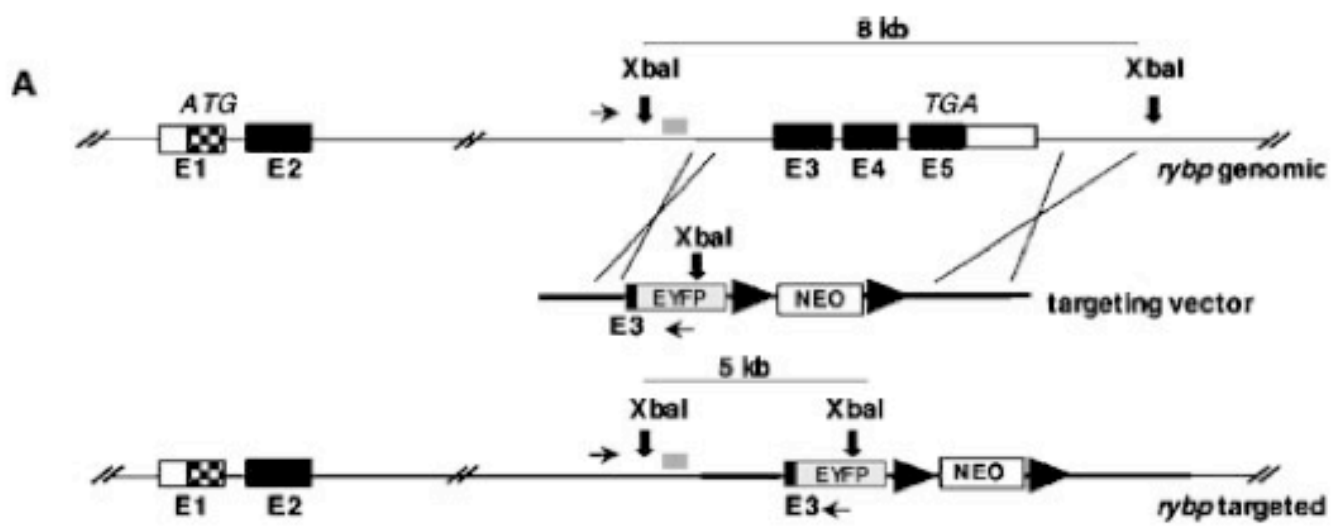

B

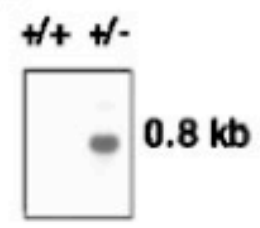

c

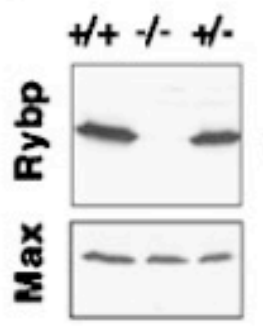

$38 \mathrm{kDa}$

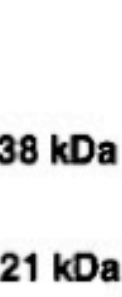

D

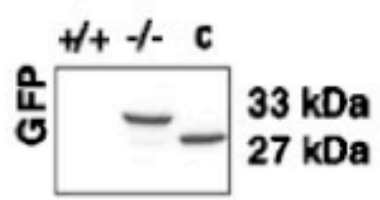

1. ábra. Az egér rybp gén homológ rekombinációval történő targetálása.

(A) Az egér rybp lókusz szerkezete (felsö diagramm); a target vektor és a targetált allél a középső és alsó diagrammokon láthatók. Az exonokat téglalapok jelölik (E1-5), az üres téglalapok a nem-transzlálódó, a satírozottak pedig a kódoló régiókat jelölik. Az 1. exon kockás régiója a gén 5' nyitott leolvasási keret (open reading frame; ORF) 
egér genom meg nem szekvenált, GC gazdag régióját jelöli. Az 2-es és 3-as exonok között a vonalon az áthúzás az intron nagy méretét $(50 \mathrm{~kb}<)$ hivatott jelölni. Az 1-es exonban levö start (ATG) és az 5-ösben elhelyezkedö stop (TGA) kodonok helye jelölt, csakúgy mint a diagnosztikus XbaI restrikciós enzimé és a helyes klónok keresésére használt 5' próbáé (szürke téglalap). A vékony horizontális nyilak a tesztelésre használt primerek helyét jelölik, amelyekkel a homológ rekombinációt detektáltuk. A targetált lókusz által kódolt fehérjetermék az 5' Rybp ORF-je (az elsö 58 aminosav) és az EYFP riporterje közötti fúziós termék (1D); ez a fúziós protein valószinüsithetően az endogén lókusz által kódolt géntermék expressziós mintázatát rekapitulálja. A “floxolt” PGK-neo kazetta (a háromszögek által határolt NEO az ábrán) szelekciós okokból szintén része a target vektornak. (B) A homológ események kimutatására szolgáló PCR reakció Southern blotja. Az „A” panelen bemutatott PCR primerek homológ rekombináció esetén egy 800 bp terméket eredményeznek. A blot $a z$ „A” panelen látható próbával (szürke téglalap) volt hibridizálva. (C) Az ES sejtekböl készült teljes sejtlizátumok immunoblot analizise: próbának anti-DEDAF; Chemicon antitestet használtunk, ami a C terminális 33 aminosavát ismeri fel. Felsö panel: A vad típusú sejtekben (rybp $\left.{ }^{+/+}\right)$egy $38 \mathrm{kDa}$ méterü fehérje termelödik, mely csökkent mennyiségben termelödik a heterozigótákban $\left(r y b p^{+-}\right)$és hiányzik a homozigóta mutánsokban (rybp $\left.{ }^{-/}\right)$. Kontrollként, ugyanabból a mintából, a 21 kDa-os Max protein (anti-Max; Santa Cruz) immunoblottja látható az alsó panelen (,,loading control”). (D) Az ES sejtekböl készült teljes sejtlizátumok immunoblot analizise antiGFP antitesttel (Molecular Probes) hibridizálva. Egy 33 kDa Rybp/YFP fúziós termék detektálható a homozigóta nullsejtekben (rybp $\left.{ }^{-/}\right)$, ami nincs jelen a vad típusú $\left(r y b^{+/+}\right)$lizátumokban. Stabilan traszfektált R1 ES sejtek, mint kontrollok, szintén láthatók a gélen melyekben az EYFP protein helyes mérete 27 kDa (c panel). A 
targetáló vektort úgy terveztük meg, hogy egy fluoreszcens riporter fehérjét, EYFP-t, juttasson be az endogén lokuszba a 3-as exon start kódjával megegyezö leolvasási keretben (in frame), valamint ezzel egyidőben a helyspecifikus rekombináció segitségével és a PGK-neo kazettát tartalmazó kazetta segítségével eltávolitsuk a 3-as exon nagy részét, illetve a teljes 4-es és 5-ös exont (lásd 1 A ábra). Az eltávolított exonok olyan funkcionálisan fontos doméneket kódolnak, amelyekröl elözöleg már kimutatták, hogy fontos szerepet játszanak a Rybp összes kulcsfontosságú kölcsönhatásának a közvetitésében. Így ez a régió kölcsönhat például a PRC1 komponensekkel, különbözö növekedési faktorokkal, DED domént tartalmazó fehérjékkel [4, 19, 20] valamint a Rybp transzkripció szabályozásában szerepet játszó faktorokkal [4]. Két targetált rybp allélt (homozigóta mutáns) hordozó embrionális össejt Western blot vizsgálata kimutatta, hogy ezekböl a sejtekböl teljesen hiányzik a 38 kD-os vad típusú Rybp fehérje, és csak a Rybp/EYFP fúziós fehérje van jelen (lásd 1C és $1 D$ ábra). Mivel a fúziós fehérjéböl hiányzik a teljes fehérjét kódoló régió 75\%a, így számos funkcionálisan fontos domén is, ezzel a targetálási lépéssel a vadtípusú Rybp fehérje funkcióit megszüntettük.

Három, függetlenül targetált ES sejtvonalból generáltunk egy-egy rybp allélt hordozó egér ES sejt vonalat (1B ábra), valamint heterozigóta keresztezéseket (intercrosses) végeztünk. A született heterozigóta utódok külsőleg normálisak voltak, termékenynek bizonyultak és nem látszott rajtuk betegségnek nyilvánvaló jele (ez a következtetés több mint 2 éves megfigyelés eredménye). Megjegyzés: a statisztikai vizsgálatok azt mutatták, hogy a született $r y b p$ heterozigóták száma lényegesen eltér a várt mendeli eloszlástól (nem mutatott adat); mert a heterozigóta állatok egy része egy 
szemi-penetráns (csak részben átadódó) fenotípus miatt elpusztul a születés után (lásd alább).

Annak meghatározására, hogy a fejlődés mely szakaszában okoz a Rybp hiánya elhalálozást, megvizsgáltuk az egérembriókat az embrionális fejlődés különböző szakaszaiban (E7.5 - E18.5 között) (1. táblázat). Ismételten nem találtunk homozigóta mutánst, ami ismét azt bizonyította, hogy a mutáció valószínüleg még a gasztrulációt megelőzően az embrió elpusztulását okozta. A gasztruláció az embriófejlődés azon kritikus stádiuma, ahol a barázdálódáskor létrejött sejtek végleges helyükre kerülnek, kialakulnak a csíralemezek, amelyekből később megindul a szervképződés. A további vizsgálódások érdekében, heterozigóta keresztezésekből származó E3.5 napos blasztocisztákat izoláltunk, majd egyenként lefényképeztük és PCR segítségével genotipizáltuk őket. A homozigóta $r y b p$ nullgenotípus kimutatható volt (1. táblázat, E3.5) és ezek a blasztociszták morfológiailag nem voltak megkülönböztethetőek a vad típusú és heterozigóta blasztocisztáktól.

\section{Táblázat. A heterozigóta keresztezésekböl származó utódok genotípus analizise.}

\begin{tabular}{|l|l|l|l|l|l|}
\hline 1 & 2 & 3 & 4 & 5 & 6 \\
\hline Kor & Normális & Abnormális & $+/+$ & $+/-$ & $-/-$ \\
\hline E3.5 & 41 & 0 & $13(33)$ & $22(56)$ & $4(10)$ \\
\hline E4.5 & 19 & 3 & $6(27)$ & $13(59)$ & $3(14)$ \\
\hline E5.5 & 38 & 7 & ND & ND & ND \\
\hline E6.5 & 65 & $17 c$ & $17(22)$ & $48(62)$ & $12(16)$ \\
\hline E7.5 & 44 & $9 R$ & $16(36)$ & $28(64)$ & 0 \\
\hline E8.5 & 37 & $9 R$ & $15(41)$ & $22(59)$ & 0 \\
\hline
\end{tabular}

1. oszlop: az embriók kora; 2. oszlop: Morfológia alapján normális kinézetü embriók száma; 3. oszlop: Morfológia alapján abnormális kinézetü embriók száma; 4. oszlop: 
Genotipizált vad típusú embriók száma; 5. oszlop: Genotipizált heterozigóta mutáns embriók száma; 6. oszlop: Genotipizált homozigóta mutáns embriók száma. R:Resorbed (felszivódott) embrió. ND: Not Determined (nem meghatározott). Zárójelben a százalákos megoszlás látható. ${ }^{C}$ : A 17 morfológiailag abnormális kinézetü embrióból 12 homozigóta, 5 pedig heterozigóta volt.

Miután sikerült kimutatni, hogy ez a mutáció az E3.5 - E7.5 közötti periódusban letális, további vizsgálatainkat erre az időszakra irányítottuk. Morfológiai vizsgálatok kimutatták, hogy az Rybp hiányos E6.5 napos embriók abnormálisak és felszívódnak mielőtt elérnék az E7.5 kort (1. táblázat).

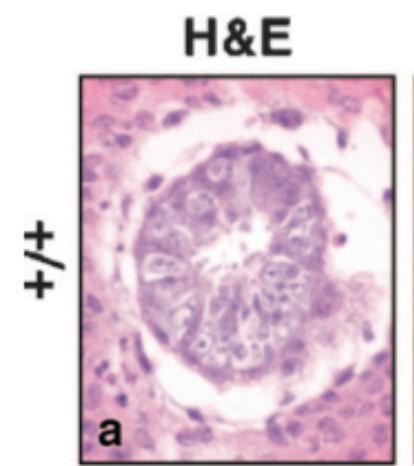

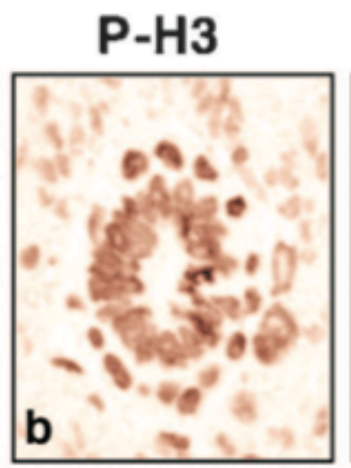

$H \& E$
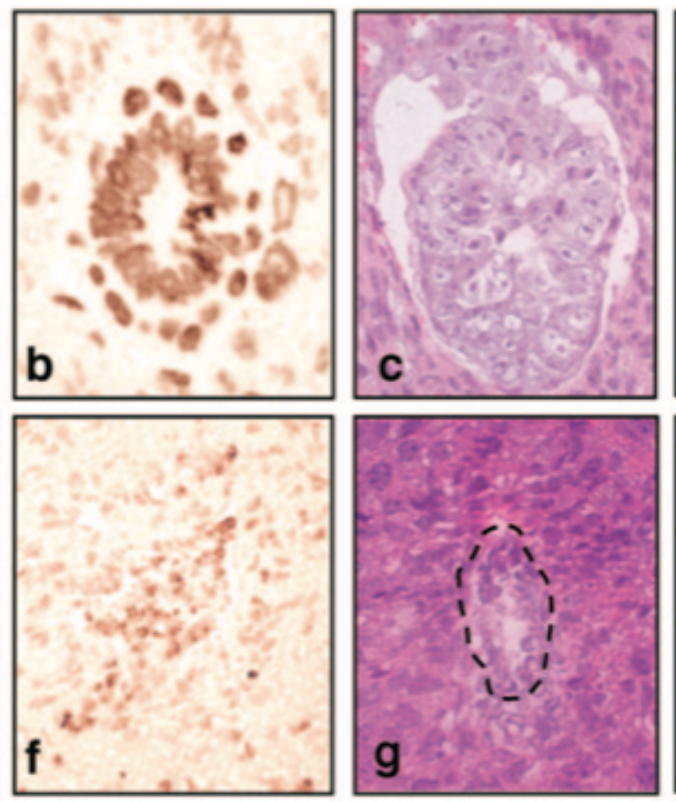

Rybp

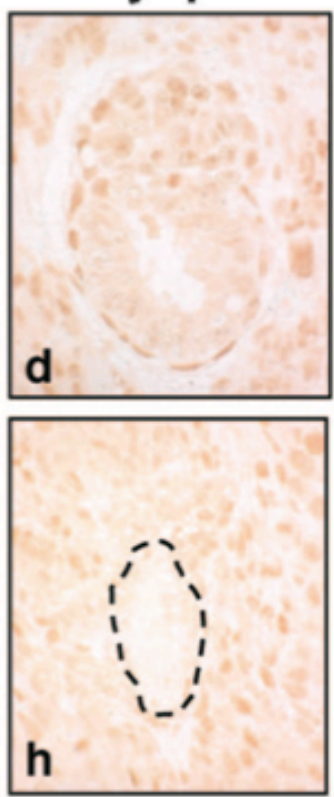

\section{2. ábra. A homozigóta embrionális letális fenotípus jellemzői.}

Reprezentatív példák a homozigóta embriók (-/-; alsó panelek) hisztológiai abnormalitásaira és csökkent proliferációjára a kontoll, vad típusúakkal összehasonlítva (+/+; felső panelek). A transzverz szekcionálású embriók hematoxilin-eozin (H\&E) festése látható az “a, c, e és $g$ ” paneleken míg a proliferációs képességet jellemzö anti-foszforilált H3 hiszton (p-H3) 
immunohisztokémiai festése $a$ “ $b, d$, f és $h$ ” paneleken. A nullembriók növekedésben elmaradottak és nem proliferálnak. Az imperfekt deciduális reakció figyelemreméltó a mutáns embriók esetében (e panel; fehér nyilak). A “c” és " $g$ ” panel E6.0 napos embriók szagittális szekcióinak a H\&E festését mutatja be. Ugyanezen embriók anti$D E D A F$ (Rybp) immunohisztokémiája $a$ " $d$ " és " $h$ " paneleken látható. A reprezentativ nullembrió (a “ $h$ ” panelen körberajzolva) megállt a fejlödésben és Rybp festödést ahogy várható, nem mutat.

Az E5.0-E5.5 korú embriók hisztológiai vizsgálata rámutatott arra, hogy a homozigóta mutánsok méretben és mintázatban is visszamaradottak voltak (lásd 2e ábra), amit könnyen lehetett azonosítani a Rybp immunoreaktivitás hiányával (pl. 2h és $2 \mathrm{~d}$ panelek összehasonlítása). A mutánsokban az embrionális és extraembrionális rétegek megkülönböztethetetlenek voltak és a feltételezett epiblaszt rendezetlen volt., A vad típusú embrióknál hengerszerü, két rétegü sejtes szerkezet volt megfigyelhető az E6.0 napra nyilvánvaló embrionális és extraembrionális komponensekkel, amelyeket klasszikusan oszlopszerü viszcerális (zsigeri; visceral) endoderma vett körül (2c ábra). Ezzel ellentétben ez a hengeres szerkezet a Rybp negatív embrióknál nem volt megfigyelhető és a sejtek a feltételezett viszcerális endoderma felől nagy méretü üregekkel rendelkeztek ( $2 \mathrm{~g}$ ábra). A rybp nullállatok esetében a poliploid óriás trofoblaszt számának csökkenése is megfigyelhető volt (nem mutatott adat). A morfológiai megfigyelésekkel összhangban, az embriók nem voltak többé megfigyelhetőek az E7.5 korra. Ebben a stádiumban nagy számú deciduális minta megvizsgálása $(\mathrm{n}<200)$ nagy felbontás mellett sem mutatott ki embrió maradványokat. 


\subsection{Proliferációs és apoptotikus defektusok a rybp null homozigóta egér embriókban}

Hogy betekintést nyerhessünk a rybp null embriók fejlődési rendellenességeinek alapjaiba, először a sejtosztódást (proliferáció) és az apoptózist tanulmányoztuk foszforilált hiszton $\mathrm{H} 3$ (p-H3) festés és TUNEL vizsgálat segítségével (2. és 3. ábra). A vad típusú embrióktól származó, osztódásra képes, embrionális és extra-embrionális sejtekkel ellentétben, amelyeknél erős p-H3 festődést találtunk, a rybp null embriókból származó E5.0 korú embriók esetében pH3 pozitív sejtek alig detektálhatóak, egy nappal később (E6.0) pedig teljesen eltűnnek ( $2 \mathrm{f}$ ábra). Feltehetően a lassú sejtosztódás nagyban hozzájárul a fejlődés leállásához ebben a korai, peri-implantációs (beágyazódás körüli) stádiumban.

A programozott sejthalált illetően miközben intenzív, "nyakláncszerü" pozitív TUNEL jel volt detektálható a beágyazódó E6-E6.5 embriók körül, addig ez a jel alig volt észlelhető a null mutáns embrióknál.

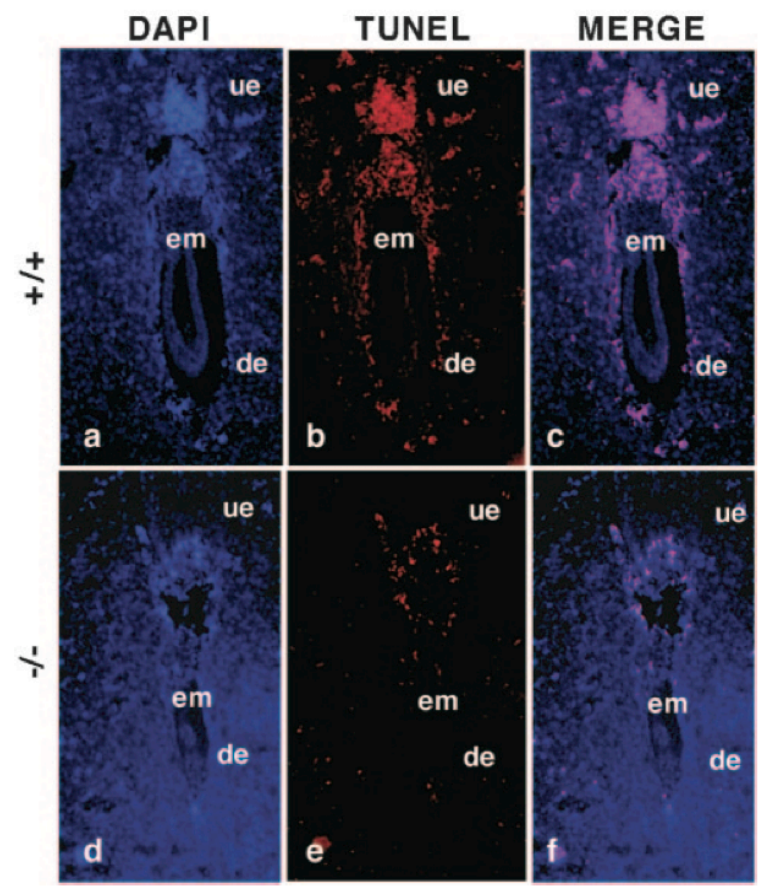

\section{3. ábra. Az apoptózis hiánya az Rybp deficiens embriókat övezö deciduában.}

Szagittális szekciók a mutáns (-/-; d, e, f) és kontroll (+/+; a, b, c) embriókból a 
méhen belüli fejlödés hatodik napja körül (E6.0-6.5). A metszetek nukleáris marker DAPI-ra (a,d) és TUNEL reakióval programozott sejthalálra (apoptosis; b, e) lettek megfestve. A két reakció egymásra vetitését a „,merge” paneleken (c és f panelek) lehet látni. A TUNEL pozitív sejtek jelenléte nyilvánvaló a kontroll embriót övezö deciduában (b) és gyakorlatilag majdnem teljesen hiányzik a mutánsokban (e). em, embrió; de, decidua epitéliuma; ue, uterin (méh) epitéliuma.

A különbség már az E5.5 stádiumban lévő embrióknál is szembetűnő. A vad típusú embrióknál megfigyelt TUNEL jel az apoptózist jelöli, amely normális körülmények között a beágyazódás folyamata alatt bekövetkezik. Elöször a méh endotéliuma hal el a blasztocisztából származó szignálok hatására, majd a deciduális sejtek visszahúzódása következik be a trofektoderma inváziójának hatására. Az a tény, hogy Evans Blue (Evans Kék) festék beinjektálásával deciduális duzzanatokat, valamint beágyazódási helyeket mutattunk ki, azt sugallja, hogy a mutáns embriók esetében is elkezdődik a beágyazódási folyamat. Azonban a TUNEL jel hiánya ezen embriók beágyazódási helyei körül azt mutatja, hogy a Rybp hiánya veszélyezteti a blasztociszta és/vagy trofoblaszt azon képességét, hogy előidézze a teljes decidualizációt.

Hogy még tovább vizsgáljuk a fejlődési rendellenesség természetét, heterozigóta kereszteződésből származó E3.5 blasztocisztákat in vitro tenyésztettünk olyan vizsgálat keretében, amely a peri-implantációs fejlődést helyettesítette. A tenyésztés 1-4 napja alatt, a blasztociszták nagy része „kibújt” a zóna pellucidából, és trofektodermális kinövéssé (TE outgrowth) és osztódó belső sejtcsomóvá (ICM outgrowth) fejlődött (4. ábra). 


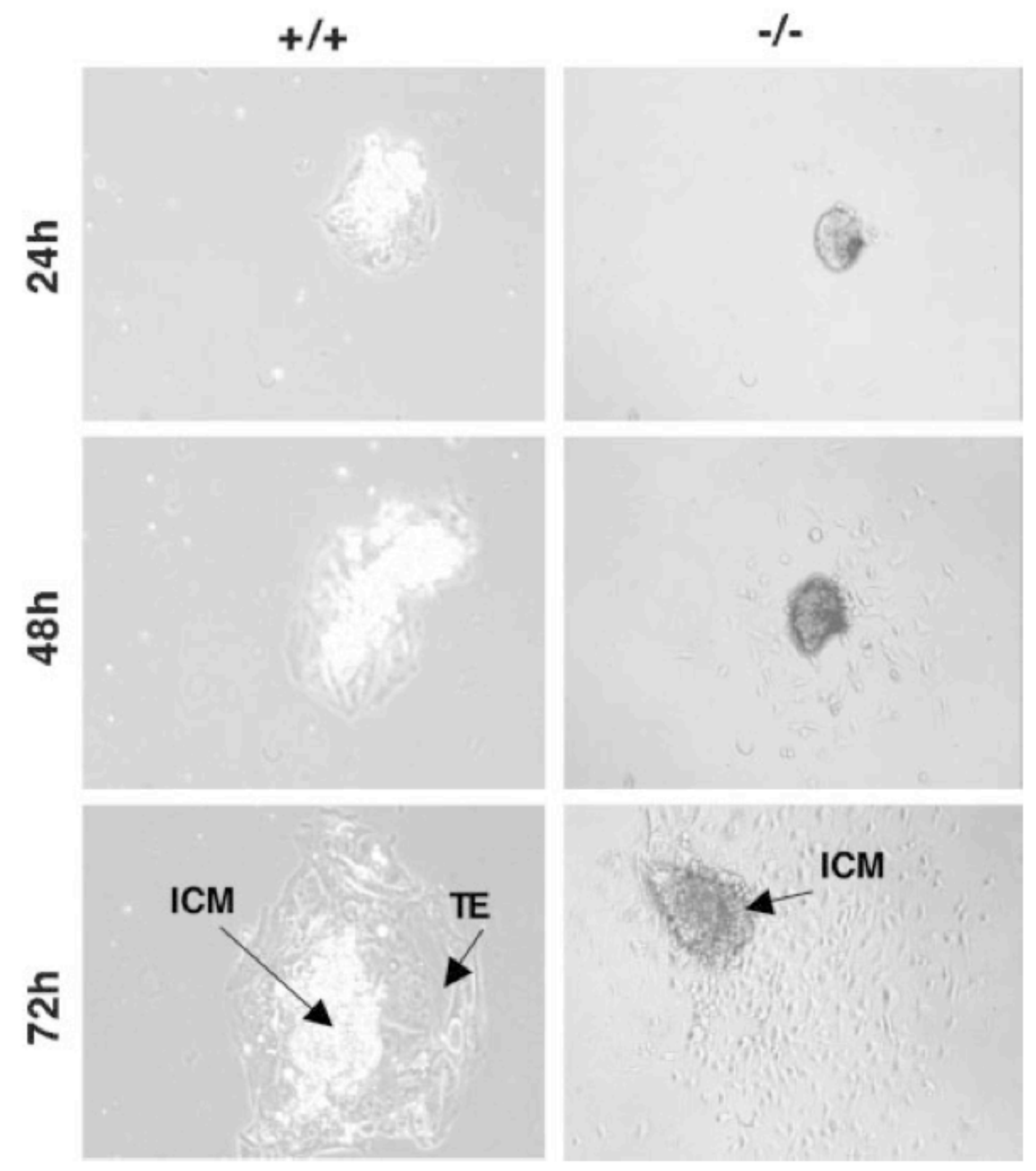

4. ábra. Az Rybp-deficiens embriók nem képesek in vitro trofektoderma sejtvonalat létrehozni.

rybp ${ }^{++}$(bal oldali panelek) és rybp-- (jobb oldali panelek) blasztocisztákat 1-4 napig (24, 48 és 72 órás idöpontok láthatók) kultúrában tartottuk annak eldöntésére, hogy képesek-e mind a belsö sejtcsomóból (inner cell mas; ICM) mind pedig az extraembionális régióból (trofektoderm, TE) sejtvonalakat kinöveszteni. A vad típusú embriókkal ellentétben az rybp $p^{-/}$blasztociszták sem proliferáló ICM sem pedig TE sejtvonalat nem voltak képesek fejleszteni. 
Ezzel ellentétben a tenyésztett blasztociszták egy része nem élt túl és TE-t sem hozott létre, csak egy néhány szétszórt endodermára emlékeztető sejtkinövés volt megfigyelhető. A vad típusú és mutáns blasztociszták genotípusát PCR-rel határoztuk meg, és az utóbbi csoportról kimutattuk, hogy szoros összefüggésben van a $r y b p^{-/}$ genotípussal. Összesítve az in vitro és in vivo megfigyeléseinket, ezek azt sugallják, hogy az Rybp szükséges a korai beágyazódást követő fejlődéshez és Rybp hiányában a beágyazódás nem megy végbe.

\subsection{Az Rybp expressziójának lokalizációja a méhen belüli fejlődés korai stádiumában}

Hogy további információkat nyerjünk a Rybp korai embrionális szerepéről, megvizsgáltuk a Rybp fehérje expressziós mintázatát az embriogenezis során a Chemicon által elöállított Rybp ellenanyag (anti-DEDAF) segítségével. Elöször is kimutattuk, hogy az Rybp detektálható a blasztocisztában és annak ES sejt leszármazottaiban (1c ábra). A beágyazódást követő fejlődéstől kezdve (E5.0 - E5.5) elszórt Rybp festődés volt megfigyelhető mind az embrionális, mind az extraembrionális részekben; az utóbbiban a festődés sokkal jellegzetesebb volt. A robosztus extraembrionális Rybp expresszió végig megmaradt a teljes embriogenezis során. Az E6.0 - E6.5 stádiumra Rybp festődés található az ektoplacentális kónuszban (EC; ectoplacental conus), az extraembrionális ektodermában (EEE), a viszcerális (VE) és parietális endodermában (PE) (a későbbi magzati extraembrionális membránok) valamint a trofoblaszt óriássejtekben (TGC) (5a és 5b ábrák, 2d ábra). 

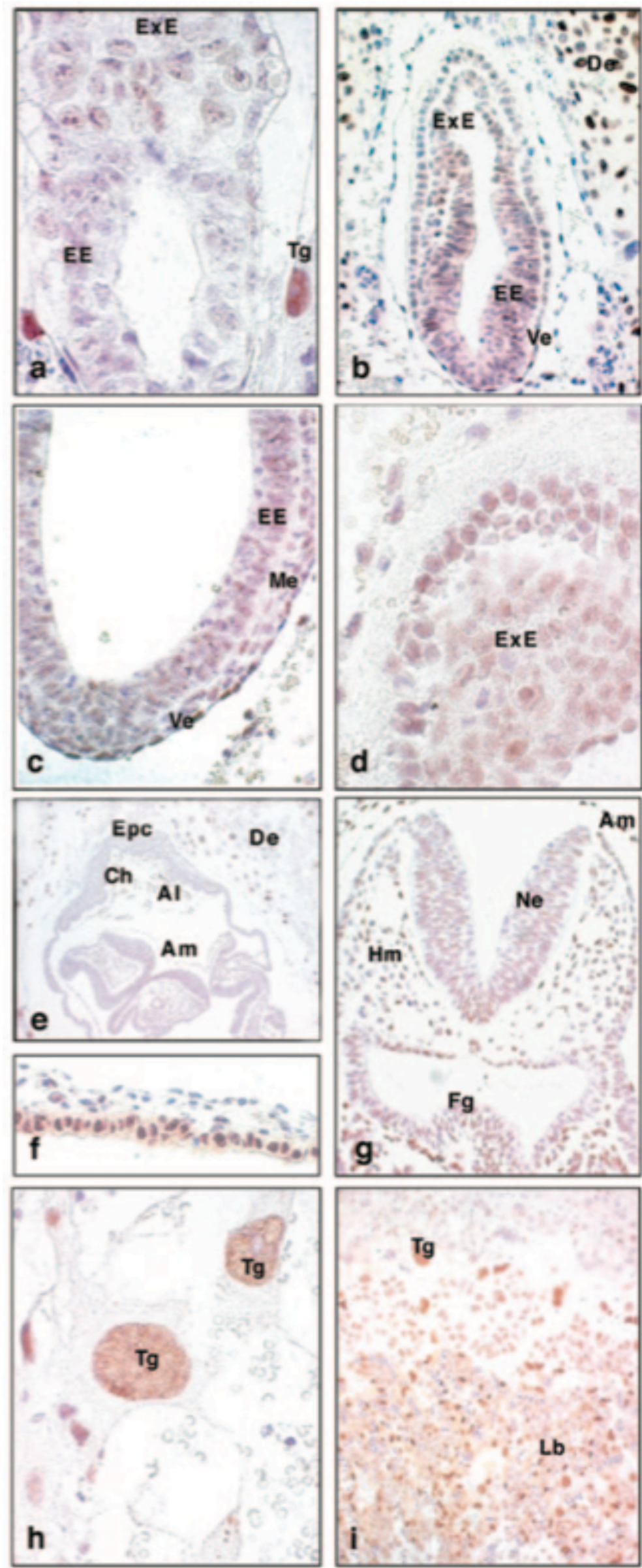


\section{5. ábra. Az Rybp expressziós mintázata a vad típusú egér embriók az implantációt}

\section{követö periódusban.}

A metszeteken korai poszt-implantációs embriók Rybp expressziója látható a fejlödés különbözö stádiumaiban (a, E6.0; b, E.6,5; c és d, E7.5; e-h, E8.5; és i, E13.5). A barna festödés a Rybp immunofestést jelöli anti-DEDAF antitesttel. A lila szín a kontraszt-festödést mutatja, ami a metszeteken való orientációt hivatott elösegíteni (Rybp negatív területek). (a) E6.0 embrió; mozaikos festödés látható minden sejtrétegben. (b) E6.5 embrió; erös expresszió a trofoblaszt sejtekben és gyengébb az epiblasztban és viszcerális endodermában. (c) E.,5 embrió; hasonló festödés mint az E6.5 embriónál a "b" panelen, kivéve hogy az újonnan megjelenö mezoderma is Rybp pozitív. (d) E7.5 embrió chorionja erösen festödik (e) E8.5 embrió chorionja és allantoisa erösen festödik (f) a magzatburok endoderma rétege erösen festödik (g) E8.5 embrió feji része erōs expressziót mutat a feji mezenhimában és a záródó neuroepitéliumban (h) Intenzíven festödö trofoblaszt sejt az E8.5 napos embriót körülvevö deciduában (i) Erös festödés az E13.5 placentában, különösen annak a belső labirintus rétegében ami az allantois és chorion leszármazottja. ExE, extraembryonic ectoderm; EE, embryonic ectoderm; Tg, trophoblast giant cell; De, decidual epithelium; Ve, visceral endoderm; Me, mesoderm; Epc, ectoplacental cone; Ch, chorion; Al, allantois; Am, amnion; Ne, neuroepithelium; Hm, head (fej) mesenchyme; Fg, foregut; Lb, labyrinth layer

Ez a festési mintázat megfigyelhető volt a későbbi stádiumokban is, az említett struktúrák leszármazottaiban: chorionban (5d és 5e ábra), allantoisban (5e ábra), magzatburokban (5f ábra), és a kifejlett méhlepényben (5i ábra). Megjegyzésképpen: E6.0 naptól kezdve, a legerősebb Rybp expressziós szinttel a posztmitotikus TGC-ek rendelkeztek, amelyek a beágyazódást követően borítják be 
az anyaméhet $(4,25$ : trofoplaszt biológiájára és a méhen belüli fejlődésre vonatkozó összefoglalás). Ami magát az embriót illeti, E6.0-E7.5 közötti időszakban, jellegzetes festődést lehetett megfigyelni néhány sejtnél, de ezeket a sejteket hisztológiailag nem lehetett besorolni egyik kategóriába sem morfológiájuk alapján (5a-5c ábra). Ez a mintázat azt sugallhatja, hogy ebben a stádiumban a Rybp expressziós mintázata sejtciklus függő. A fejlődés és szervképződés előrehaladtával alacsony Rybp szint volt megfigyelhető az embió szöveteinek egy részében, majd időben előrehaladva, a fejlődés bizonyos szakaszaiban sejt/szövet specifikus Rybp upreguláció figyelhető meg (pl: neuronok, a mezenhimális és endoteliális sejtekben) (pl. 5g ábra, nem közölt adat, [4]). A fent említett genotípussal együtt ez az expressziós mintázat megegyezik azzal az elképzeléssel, hogy a beágyazódási folyamat bekövetkeztének ideje körül a Rybp nélkülözhetetlen az extraembrionális szövetek normális fejlődéséhez/müködéséhez és valószínűleg az embrió számára is.

\subsection{Rybp szintjének csökkenése befolyásolja a központi idegrendszer normális fejlődését}

Annak érdekében, hogy a Rybp hiányos (deficiens) sejtek fejlődési képességét tanulmányozni tudjuk, kiméra állatokat hoztunk létre. A targetált homozigóta sejteket $\left(r y b p^{-/}\right)$vad típusú $\left(r y b p^{+/+}\right)$blasztocisztákba injektáltuk, hogy kiméra embriókat nyerjünk. Ezekben a kimérákban, az epiblasztot heterogén sejtpopuláció alkotja $\left(r y b p^{+/+}\right.$és $r y b p^{-/-}$sejtek), míg a primitív endoderma és trofektoderma a vad típusú gazda blasztocisztából származnak [21]. Az embrió saját mutáns sejtjei is megkülönböztethetőek a vad típusúaktól a bevitt EYFP riporter fehérje segítségével, amely sárgán fluoreszkál a mutáns sejtekben. 
A kiméra embriókat hordozó nőstényeket a terhesség különböző stádiumában (a terhesség E8.0 napjától az E13.5.) disszektáltuk és mintegy 50 embriót vizsgáltunk meg morfológiailag és fluoreszcens mikroszkóppal.
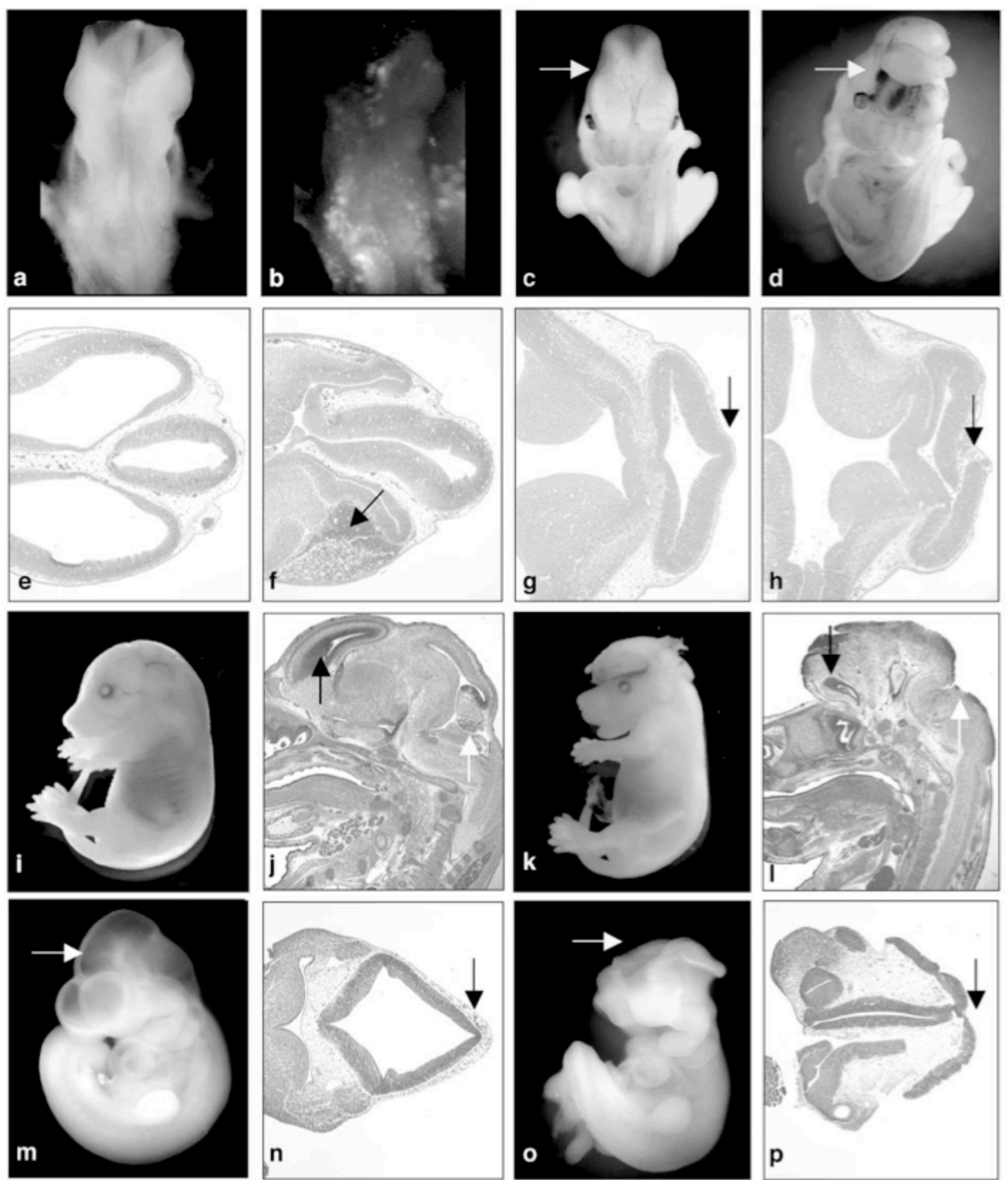

6. ábra. Az Rybp normális szint alá csökkenése CNS fejlödési rendellenességeket okoz.

(a-h) Rendellenességek a rybp $p^{-/-}<_{->} r y b p^{+/+}$kiméra embriókban. Poszterior nézetü fény (a) és fluoreszcens (b) mikroszkópos felvételek E8.5 kiméra embriókról. A „,b” 
panelen látható fluoreszcens sejtek rybp ${ }^{-/ ~ E S}$ sejtekböl erednek. Megjegyzés: a rybp $p^{-/}$ ES sejtek csak kis mértékben képesek hozzájárulni az embriók fejlödéséhez. Nagyobb arányú hozzájárulás letalitást okoz. (c, d) Fénymikroszkópos nézete egy kontroll (c) és egy kiméra (d) E11.5 embriónak. A kiméra agya súlyos morfológiai elváltozásokat és erös túlburjánzást mutat. (e-h) Koronális hisztopatológiai metszetek kontroll (e, g) és kiméra (f, h) embriók feji régiójából. Megjegyzés: kaotikus túlnövés, sztenózis, hemorrágia az elöagyban és nyitott velöcsö részek (nyíl a " $h$ " panelen) jellemzik a kiméra embriókat. (i-p) Rendellenességek a rybp ${ }^{+/}$heterozigóta ( $k$, o) embriókban a kontrollokkal (i, m) összehasonlítva: nyitott velöcsö fenotípus. (i, k) E16.5 embriók. (m, o) E10.5 embriók. A j, l, n, és p panelek a következő embriók megfelelöi: j, embrió $i$; l, embrió $k$; $n$, embrió $m$; p, embrió o; (j,l), szagittális metszet. (n,p) koronális metszet. Megjegyzés: Struktúrális diszorganizáció, ventrikuláris sztenózis (fekete nyil "j" és "l" paneleken) és a kisagy teljes hiánya (fehér nyil "j" és "l" paneleken) látható az agyi régióknál a heterozigótákban. A nyitott velöcső defektus nyilvánvaló fenotípus a „p” panelen látható heteozigótánál (nyilak; összehasonlítva a kontroll „,n” embrió metszettel).

A homozigóta mutáns sejtek csak csekély mértékben voltak képesek az embriók fejlődéséhez hozzájárulni,, a homozigóta nullsejtek főleg a végtagokon és kötőszövetekben jelentek meg nagyobb számban (6b ábra), amelyet a disszociált embriók áramlásos citométeres és sejtválogatás (FACS) vizsgálatai is alátámasztottak: átlagosan 12\% YFP pozitív sejt volt detektálható egy-egy embrióban (nem mutatott adatok). Ezek az adatok és az a tény, hogy egy jelentős számú (körülbelül 50\%) korai rezorpció (az embriók korai "felszívódása)" volt megfigyelhető a terhes deciduán, azt sugallják, hogy a nagyszámú deficiens ES sejt jelenléte nem összeegyeztethető az embrionális túléléssel. 
További érdekes megfigyelés, hogy a terhesség középső szakaszától a kiméra embriók jelentős részénél (E9.5-től amikor is a neurulatio neuroláció (az idegrendszer telepének elkülönülése az ektodermától) befejeződik és kialakul az agy) a központi idegrendszer hibás formációja volt megfigyelhető (6d és 6c összhasonlítása). Az E11.5 - E13.5 kiméra szekciók szövettani vizsgálata feji (cephalic) rendellenességeket mutatott ki, mint pl.: szerkezeti rendezetlenség és konvolúció, masszív hiperplázia, ektopikus neurális szerkezetek. Ezek a rendellenességek a legtöbbször az előagyban találhatók, míg a tel- és dienkefalikus régiók differenciálódása bekövetkezett, noha mindkét régióra jellemző volt a rendezetlen túlnövés és betüremkedés, valamint az összezsugorodott kamrák (ventriculumok) (reprezentatív a $6 f$ és 6e panelek összehasonlítása). Az előagyban és a hídban ugyancsak megfigyelhetőek voltak olyan területek, ahol a velőlemezek velőcsővé nem, vagy részlegesen záródtak. Ez a jelenség szokatlan módon együttjárt a felszínt borító ektodermális réteg fúziójával (6h és $6 \mathrm{~g}$ ábrák). Ennek magyarázatát jelenleg nem tudjuk.

Az a megfigyelés, hogy a kiméra állatokban a központi idegrendszer károsult, azt tükrözi, hogy a központi idegrendszer normális fejlődéséhez szükség van a Rybp expressziós mintázatának térbeni és időbeni összehangolására. Ezt az elméletet látszik alátámasztani az a megfigyelés is, hogy a Rybp heterozigótáknak egy része (körülbelül 15\%) elpusztul NTD (neural tube defect) következtében a születes környékén (perinatal) mindhárom független sejvonalban (6k és j ábrák összehasonlítása). A heterozigóták korábbi fejlődési stádiumokból való analízise (E9.5-10.5) kimutatta, hogy az enkefália a velőcső (,neural tube”) inkorrekt záródása következtében és nem egyéb okokból, mint pl. a koponyacsont helytelen záródása miatt alakul ki (6o és p panelek összehasonlítása $6 \mathrm{~m}$ és $\mathrm{n}$ panelekkel). A velőcső záródása normál esetben (vad típusú állatban) az embrionális fejlődés 8.5 napjánál az 
előagy hátsó, kaudális részénél kezdődik (E8.5) majd fokozatosan terjed át az elülső (anterior) agyi régiókra és egy napon belül befejeződik (E9.5) $(3,12)$. Az, hogy a Rybp heterozigóták egy részében ez a folyamat inkomplett és még a tizedik napon (E10.5) is nyitva van a velőcső azt sugallja, hogy a velőcsőzáródás folyamata érzékeny a Rybp mennyiségére (Rybp dózisfüggő).

\subsection{A Rybp fehérje immunolokalizációja a fejlődő CNS-ben}

Annak vizsgálatára, hogy betekintést nyerjünk a Rybp CNS fejlödésben betöltött szerepére elsőként annak expresszióját vizsgáltuk meg immunohisztokémiai módszerekkel egér embriókban (7. ábra). 


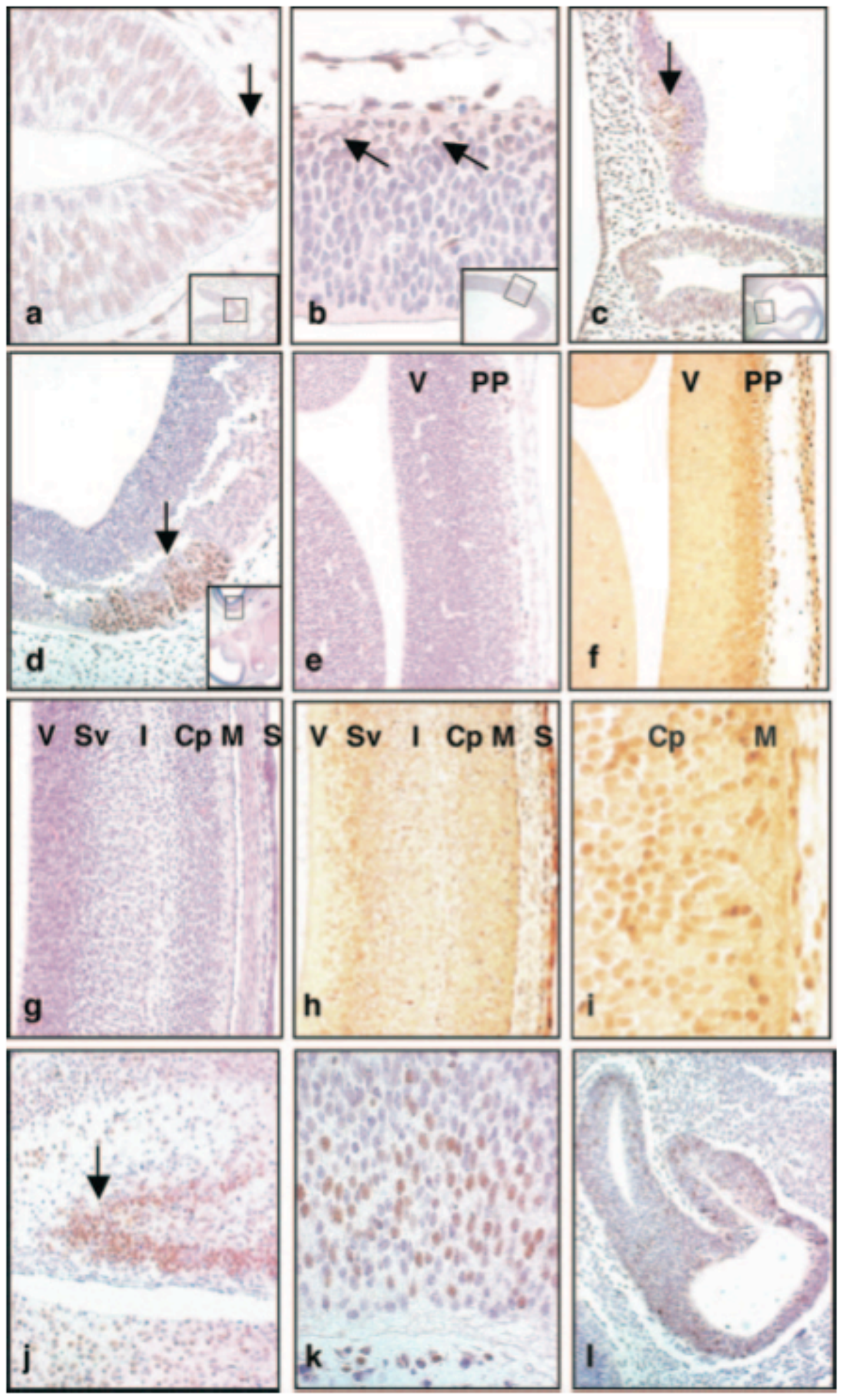




\section{7. ábra. A Rybp expressziós mintázata a vad típusú egér embriók központi}

idegrendszerében.

Reprezentativ metszetek az erös Rybp festődést mutató agyi régiókból különbözö embrionális fejlödési stádiumokból. A barna festődés a Rybp expressziót jelöli. A metszetek "a-d és "j paneleken hematoxilin-eozinnal (H\&E) is kontraszt-festettek. (a) Nagy nagyitású felvétel egy E8.5 napos kontroll embió neuroepitéliumáról. A jobb alsó sarokban (és az 5. ábrán is) ugyanazon embrió kis nagyitású képe látható. A nyíl a „,median hinge point”-ra mutat (a) ami az összezáródó velöcsö közepén található) és Rybp expressziót is jelöl egyben. (b) E10.5 embió neopalliuma. A nyilak az erös Rybp expresszió helyét jelölik a legkülsö sejtrétegekben. (c) E10.0 embrió ventrális diencephalonja (köztiagy) (nyill), alatta a Rathke's pouch (Rathke-tasak) (d) E10.0 embrió rhombencephalon-hólyag isthmusa (e-i) Sztratifikált Rybp festödés a fejlödö neocortex rétegeiben. (e,f) Hematoxilin-eozin (H\&E) és anti-DEDAF festése az E11.5 neocortexnek. Megjegyzés: a ventrikuléris régió (V) negatív, a preplate (PP) pedig pozitiv Rybp-re. (g-i) H\&E és anti-DEDAF festése az E16.5 neocortexnek. Megjegyzés: a ventrikuláris régió (V) negativ, a preplateból származó cortical plate (Cp) és marginal zóna (M) pedig pozitív Rybp-re. A külső vetrikuláris/szubventrikuláris zóna határa szintén pozitiv. $V$, ventricular zone; Sv, subventricular zone; I, intermediate zone; $P P$, preplate; $C p$, cortical plate; $M$, marginal layer; S, skin. (j) Erös specifikus festödés újszülött egér gyrus dentatus-ában (a hippocampus része). (k) E16.5 embrió gerincvelejéböl származó neuroblastok pozitívan festödnek Rybp-re. (l) E11.5 embrió szaglóhámja: eröteljes Rybp festödés az epitéliumban.

E8.5 időpontnál a pszeudosztratifikált neuroepiteliális sejtekben mérsékelt Rybp festődés látható. Különösen a neurális plate bizonyos régióiban, az úgynevezett 
„median hinge point” sejtjeiben mutat specifikusan erősebb festődést (7a és $5 \mathrm{~g}$ ábrák). E10.5 napra az előagyi régió (di-és telenkefalon) neuroblasztjaiban, az isthmusban (a középagy és rhombencephalon közötti rész melybök később a hidak, medulla oblongata és kisagy fejlődnek ki) és a dorzális hídi régiókban (7d panel) is kifejezett festődést mutat. Ez összhangban van egy, már korábbi tanulmányban megfigyeltekkel [4], mi szerint Rybp mRNS-t mutattak ki a CNS bizonyos régióiban. E11.5-től kezdődően a kialakuló nagykéreg (cerebral cortex; előbb „preplate”) külső, posztmitotikus neuronokat tartalmazó rétegét jelöli, míg a ventrikuláris, proliferatív zóna sejtjei konzekvensen negatívan festődnek (7e panel). Ez a tendencia E16.5-nál is fennáll, ahol a külső, marginális zóna neuronjai (a preplate derivatívjai) mutatják a legerősebb festődést. Ezzel egyidőben a belsőbb rétegben egy vékony sávban közvetlenül a ventrikuláris zóna felett is látható egy halványabb festődés $(7 \mathrm{~g}-\mathrm{i}$ panelek) [22]. Erős és specifikus festődést mutattak továbbá a gyrus dentatus (dentate gyrus) sejtjei a hippokampusznál (7i panel), a periferiális és kraniális ideg gangliumai, a feji régió mezenchimális szövetei, a gerincvelő (7k panel) és a szaglóhám sejtjei (71 panel). Összességében ezek az adatok azt támasztják alá, hogy a Rybp gén specifikus, disztinktív upregulációt mutat a CNS specifikus régióiban, illetve sejttípusaiban és a nagykéreg fejlődése folyamán az érett neuronok kialakításában. Fontos megemlíteni hogy a rokon Yaf2, legalábbis részben, átfedő expressziós mintázatot mutat [10]. Ez a részben átfedő expressziós mintázat a Rybp és Yaf2 között azonban nyilvánvalóan nem elégséges a heterozigóta és kiméra állatokban Rybp hiány következtében kialakult defektusok kompenzálására (6. ábra).

Az eredmények azt mutatták, hogy a Rybp gén megnyilvánulása fontos az egér központi idegrendszerének kialakításában. A továbbiakban megvizsgáltuk, hogy vajon egyéb szervek is érintettek-e a Rybp mutáció által, különös tekintettel a közös 
fejlődési eredettel bíró, primitív ektodermából kialakult szervekre. Mivel nemcsak az agy, hanem a szemlencse és retina is ektodermális eredetü, így elsőként megvizsgáltuk a Rybp expresszióját a szem embrionális fejlődése folyamán (8. ábra).
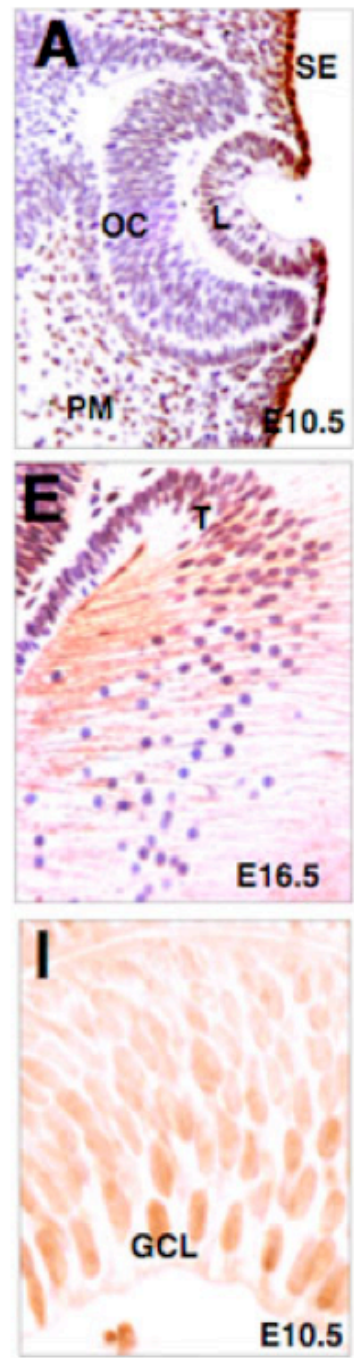
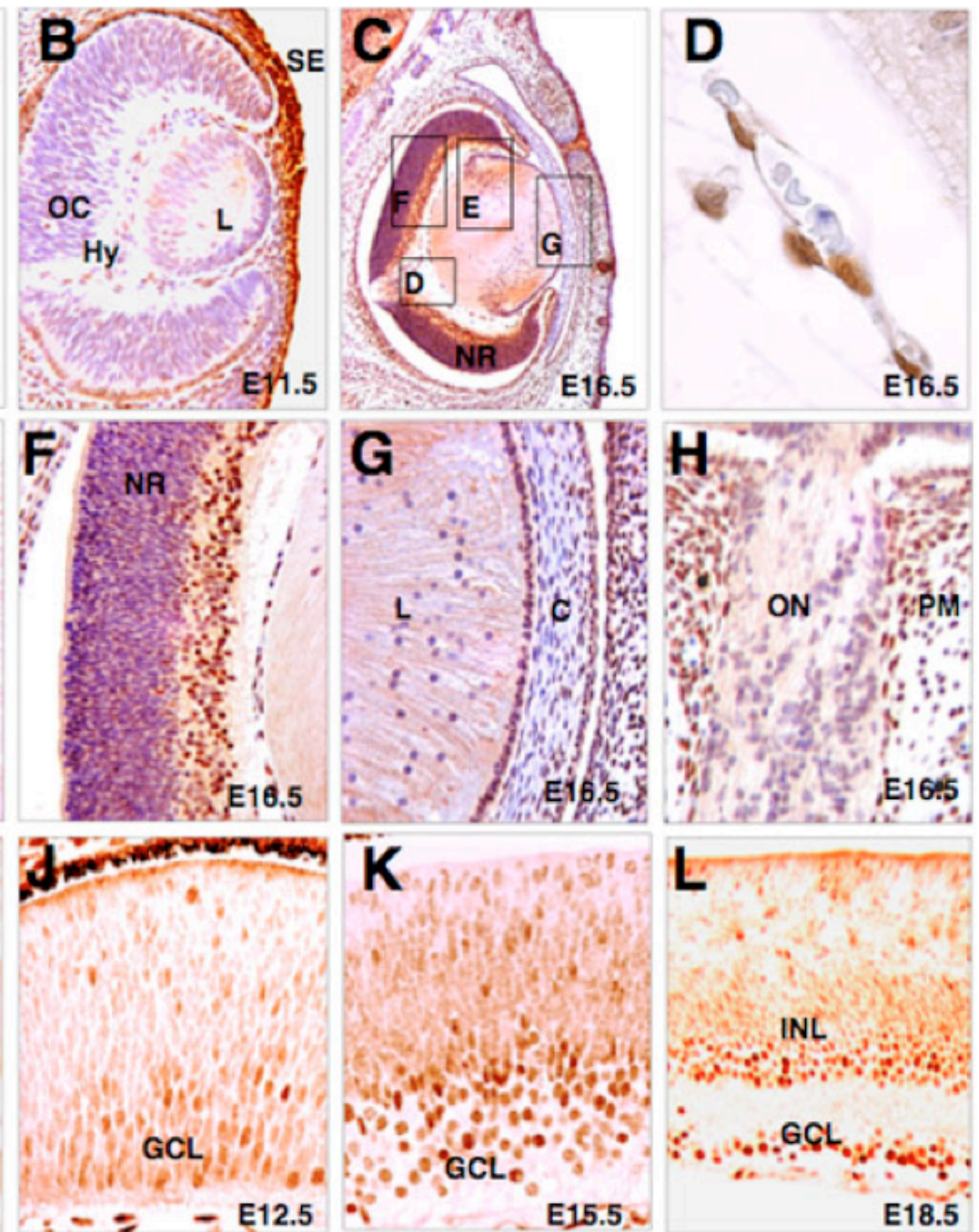
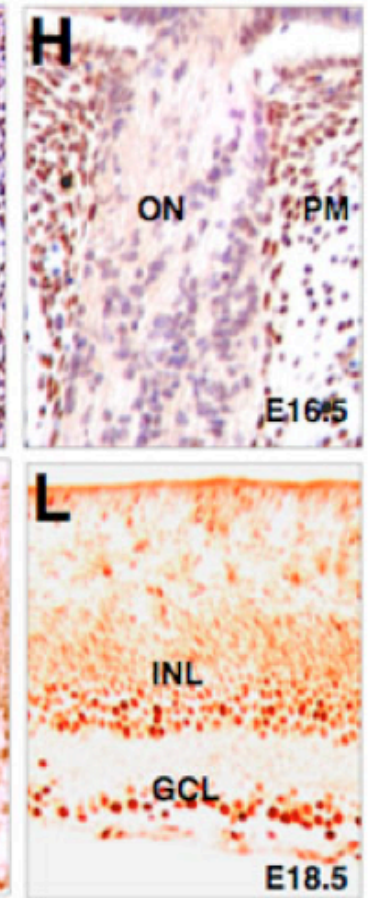

8. ábra: A Rybp expressziós mintázata a szemben vad típusú egér embriók prenatális fejlödése során.

(A-H) Szagittális metszetek Rybp festödése (barna) E10.5 (A), E11.5 (B) és E16.5 (CH) idöintervallumokban. A metszetek hematoxilinnal is kontraszt-festettek az " $a$ - $h$ " panelekben. Nagyobb felbontású felvételek a "C" panel megfelelö régióiról az " $E-H$ " paneleken láthatók. (I-L) A Rybp festödés felerösödését mutatják a neuroretináról készült felvételek E10.5 (I), E11.5 (J), E13.5 (K) és E18.5 (L). C; szaruhártya, E; 
embrionális, GCL; ganglion sejtréteg, INL; inner nuclear layer, L; lencse, NR; neuroretina, ON; látóideg, PM; periocularis mezenhima, SE; surface ectoderm (felszíni ektoderma), OC; optic cup. Nagyítások: $A(\times 460) ; B(\times 320) ; C(\times 250)$; $D(\times 800) ; E-H(\times 400) ; I(\times 630) ; J(\times 460), K(\times 320) ; L(\times 250)$.

A szem úgy fejlődik, hogy az agyból mindkét oldalt egy-egy "hólyag" ("vesicle”) nő ki. A hólyagból lesz a szem ideghártyája, míg a szemhólyagot az aggyal összekötő kocsány látóideggé alakul át. A szemlencse a bőrhám átalakulása útján keletkezik és így kerül a betüremlett szemhólyag legkülsőbb része belülre. Egerekben a szem fejlődése embrionális korban a kilencedik napon kezdődik (E9.0). Erős Rybp festődést először E10.5-nél láttunk, amikor is Rybp festődés a betüremkedő lencseplacodot (lens placode) körülvevő felszíni hámréteget („surface ectoderm"; SE) jelöli (8A panel). Szintén festődés volt látható közvetlenül a SE alatt a szem körüli mezenhimában (periocular mesenchyme; POME) és a kialakuló szemkehelyben vagy szemserlegben (optic cup; OC, 8A panel). Az E11.5 naptól látható volt mind a szemhólyagok (lens vesicle; Lv) elülső részének sejtjeiben, mind a meghosszabbodó elsődleges szemrostok (elongating primary lens fiber; PLF) sejtmagjában és a hyaloid plexusban (8B panel), ami később a szem vérellátását adja. A fejlődés előrehaladtával az Rybp fehérje végig perzisztens festődést mutatott a hyaloid üreg sejtjeiben és a SE-ban (8C panel). E14.5 és E16.5 napok között erős festődés látható a másodlagos lencse rostok sejtmagjában (secondary lens fiber; SLF (E16.5 8C, E panelek)) és a a neuroretina ventrális részében (E16.5 8C, F panelek). E16.5 napnál szintén detektálható a lencse epitéliumban (1C, G panelek).

A szaruhártyában is erősen festődő részek voltak kivehetőek, amely a korneális epitélium és néhány sejt a sztómában (8G panelek) voltak. Nem egyenletes 
gyenge festődés volt látható a szemideg rostjaiban (optic nerve; ON) és erősebb a szemet körülvevő mezenhimális szövetekben (8H panel). A legmarkánsabb változás, hogy a korai stádiumokban a még differenciálatlan sejtekben gyenge festődés, míg az embriogenezis és a differenciáció előrehaladtával egyre erősebb festődés detektálható. Ez különösen szembetűnő a retina esetében, ahol időben és térben egyre több réteg alakul ki differenciálódott sejtekkel, mint például a ganglion (GGL) vagy a belső nukleáris (inner nuclear; INL) és fotoreceptor réteg (8I-L).

A szem embrionális expressziós mintázatának analízise után meghatároztuk a születés utáni szem expressziós mintázatát is.
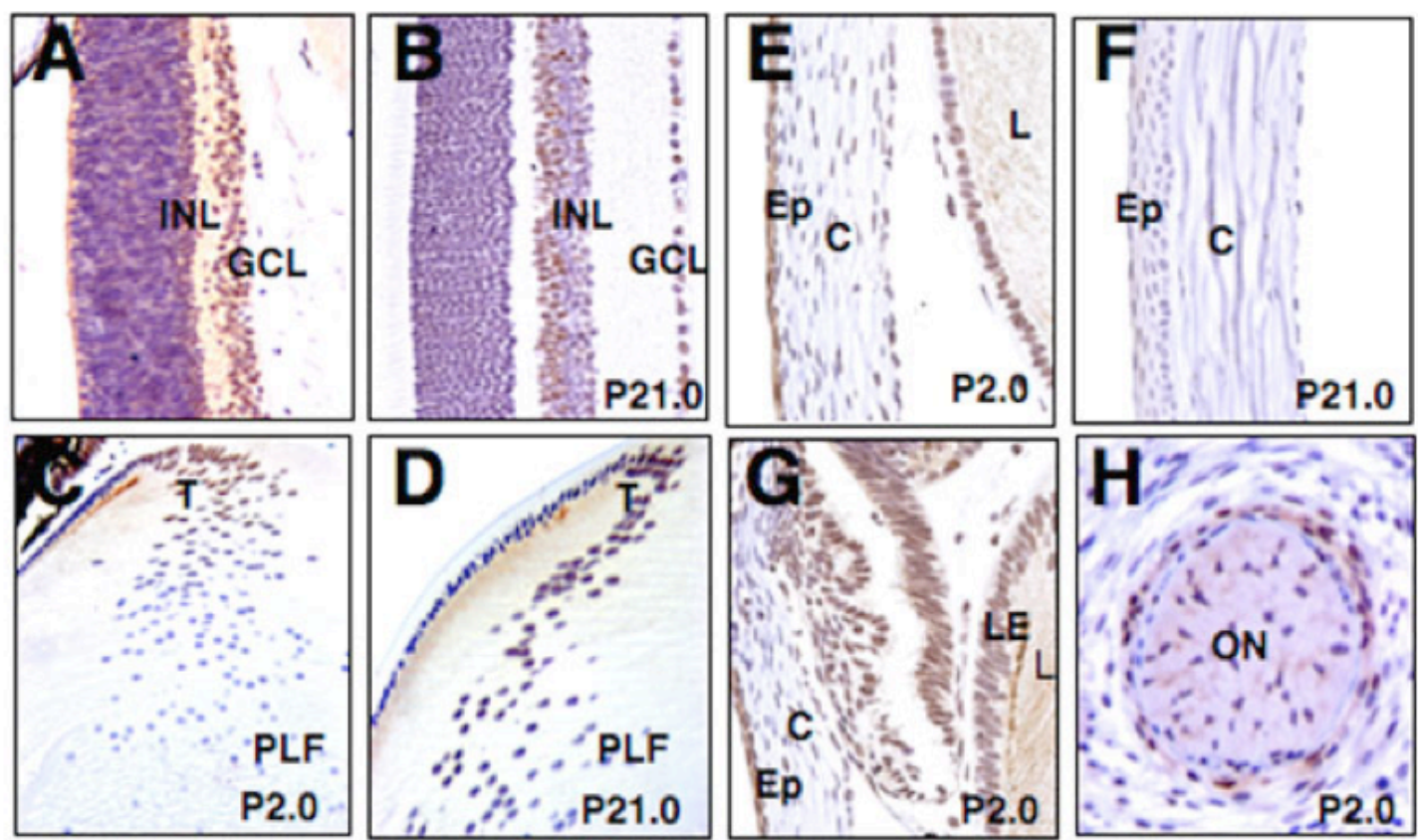

9. ábra: A Rybp expressziós mintázata a szemben vad típusú egér embriók posztnatális fejlödése során.

A szemröl készült szagittális metszetek a látóideg (optic nerve; ON) magasságában készültek a születés utáni második (P2; A, C, E, G, H), és huszonegyedik (P21 B, D, és $F)$ napokon. (A, B) retina, $(C, D)$ lencse, cornea $(E, F)$, connectiva $(G)$ and optic nerve (H). C; cornea, Ep; corneal epitélium, GCL; ganglion cell layer, INL; inner 
nuclear layer, L; lencse, LE; lencse epitélium, ON; látóideg (optic nerve), PLF primary lens fiber cells, $T$; tranzíciós zóna $P$; postnatal day (születés utáni). Nagyítás: $(320 \times)$

Kettő (Postnatal; P2 2A, C, E, G panelek) és huszonegy (P21; P2 2B, D panelek) nappal a születést követően intenzív festődés latható a GGL és differenciálódó INL-ekben, specifikusan annak dorzális részén, ahol a bipoláris és horizontális sejtek képződnek (9B panel). Kifejezett festődés volt megfigyelhető a korai PLF fejlődés stádiumában (9B panel). A már érettebb lencsében a festődés nem volt többé látható sem a PLF-ben sem pedig a lencse epitéliumában (9C, D panelek). Ezzel szemben erős Rybp expressziót észleltünk a tranzíciós zónában, ahol a SLF sejtjek fejlődése megy végbe (9C, D panelek). P2 napon gyakorlatilag az összes Ep sejt pozitivitást mutatott és sporadikus festődés volt megfigyelhető az Ep-ban, sztrómában és bazális membránban (9E panel). A huszonegyedik napra (P21) már nem volt megfigyelhető festődés, noha az Ep-ban még gyengén expresszálódott (9F panel). Végezetül erős expresszió volt megfigyelhető a születés utáni stádiumokban a kötőszövetekben (connectiva) és egyenletes festődést mutatott az ON környezetében (9H panel). A Rybp dinamikus sejt-típus függő expressziós mintázata felveti annak a lehetőségét, hogy a génnek meghatározott és specifikus funkciói vannak bizonyos sejttípusok kialakulásában és fenntartásában a szem fejlődése során.

\subsection{Az $r y b p^{+/}$embriók egy része szem fejlődési rendellenességeket mutat}

Az rybp+/- embriók egy csoportja kolobómában (coloboma) szenved: Előzőleg már kimutattuk, hogy a rybp heterozigóta nullembrióknak egy része agyi fejlődési rendellenességben szenved, mely magábafoglalja az előagy megnövekedését és enkefáliát [23]. Mivel a retina az előagyból fejlődik ki, a következőkben azt 
vizsgáltuk, hogy ezeknél az állatoknál milyen valószínűséggel jelenik meg abnormalitás a szemfejlödésben. Az exencephaly-ban szenvedő $r y b p^{+/}$egerek különböző fejlődési szakaszokban (E12.5-tól születésük utánig) történő vizsgálata során azt kaptuk, hogy az egerek 32\%-nál (19-böl 6) figyelhető meg retina/latóideg kolobóma (10A es 11B ábrák összehasonlítása).

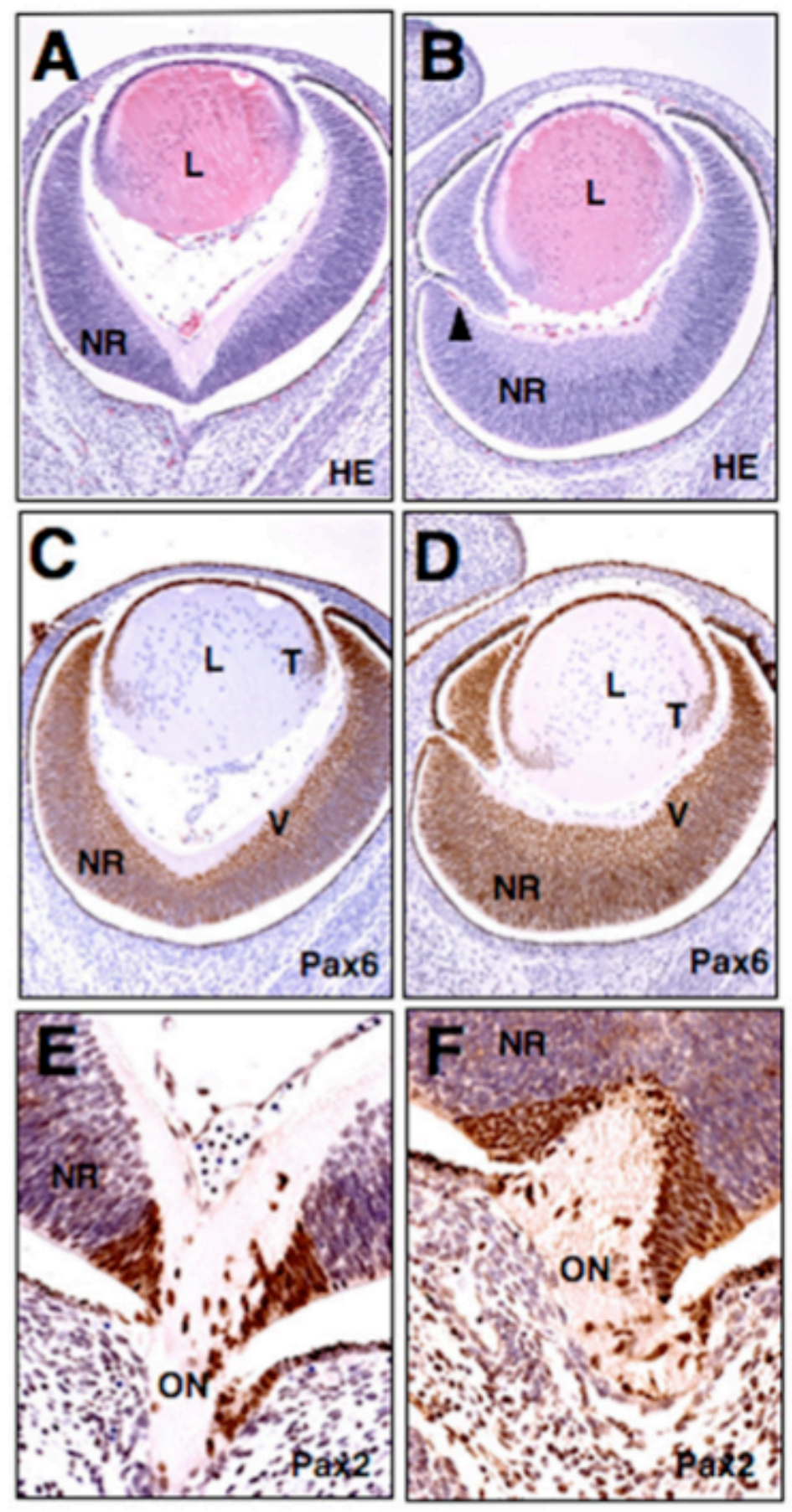

10. ábra: Kolobóma az rybp ${ }^{+/-}$egér embriókban. 
(A,B) Vad típusú (A) és rybp ${ }^{+/}$heterozigóta (B) szemek hematoxylin és eozin festett koronális szekciója E1.,5 napos korban. A mutáns szem neuroretinája erösen megvastagodott és nem záródott össze, ami kolobóma kialakulásához vezetett (B; nyilfej). (C,D) Pax6 immunofestés a vad típusú (C) és mutáns (D) szemeken. Normális esetben a Pax6 a neuroretina ventrális oldalán expresszálódik. Azon kívül, hogy a mutánsokban expressziója a ventrális oldalra korlátozódik, a lencse tranzíciós zónájában is eltolódik posterior irányba (C és D összehasonlitása). (E, F) Pax2 immunofestés a vad típusú (E) és mutáns (G) szemben. L; lens, NR; neuroretina, ON; optic nerve, V; ventral, T; transi- tional zone. HE; hematoxylin és eozin. Nagyítások: $A-D(\times 320) ; E-F(\times 460)$

Az ilyen kolobómákat az esetek nagy többségében az optic fissure inkomplett bezáródása okozza, ez a folyamat normál körülmények között az E13.5 korra bekövetkezik [24]. Mind egyoldali, mind kétoldali $r y b p^{+/}$kolobómák megfigyelhetőek voltak. Ráadásul a $r y b p^{+/}$szemek megvastagodott neuroretinával rendelkeztek a szemlencse ventrálisan rotált és a szemlencsében rosszul helyezkedett el (10B ábra összehasonlítva a 10A-val). A látóideg szintén gyakran visszafejlődött (10F). A kolobómák kifejlődésének egyik lehetséges magyarázata az, hogy a mutáns retinákban az alacsony Rybp fehérje szint a különböző reguláló fehérjék, mint Pax6 [25] és Pax2 [24, 26] normális eloszlását is befolyásolja. Mindkét fehérjéről, a Pax6ról és a Pax2-röl is kimutatták, hogy nélkülözhetetlenek az szemserlegnyél-hasadék (optic fissure) megfelelő bezáródásához (“master-regulátor”). Ennek megfelelően vizsgáltuk, hogy az rybp mutáns szemekben megváltozott-e a Pax6 es Pax2 immunolokalizációja. Normális körülmények között a Pax6 fehérje a retina ventrális felében helyezkedik el és a vad típusú állatok esetében az E12.0 korra teljesen eltünik 
a fejlődő látóidegböl [27]. Az rybp mutáns embriókban azonban a Pax6 festődés szétterjedt a retina teljes vastagságában (10C, D). Ezzel ellentétben a másik "masterregulátor" Pax2 transzkripciós faktor szintje nem változott a mutáns szemekben (10E és 10F ábrák összehasonlítása).

A neuroprogenitor és a postmitotikus neuronális sejtek közötti megfelelö arány fontos a helyes retina-fejlödéshez és ennek a morfogenezis folyamatnak a felborulása okozhatja a kolobómák kialakulását [28]. Ennek megfelelően vizsgáltuk, hogy vajon a mutáns retinákban (amelyben a kolobóma fenotípus megjelenik) változik-e a korai és késői neuronok aránya. Vizsgálataink azt mutatták, hogy a prenatális mutáns retinában, a specifikus neuronális sejtmarkerek expressziós mintázata azonos volt a kontroll egerek retinájában megfigyelt markerekével.

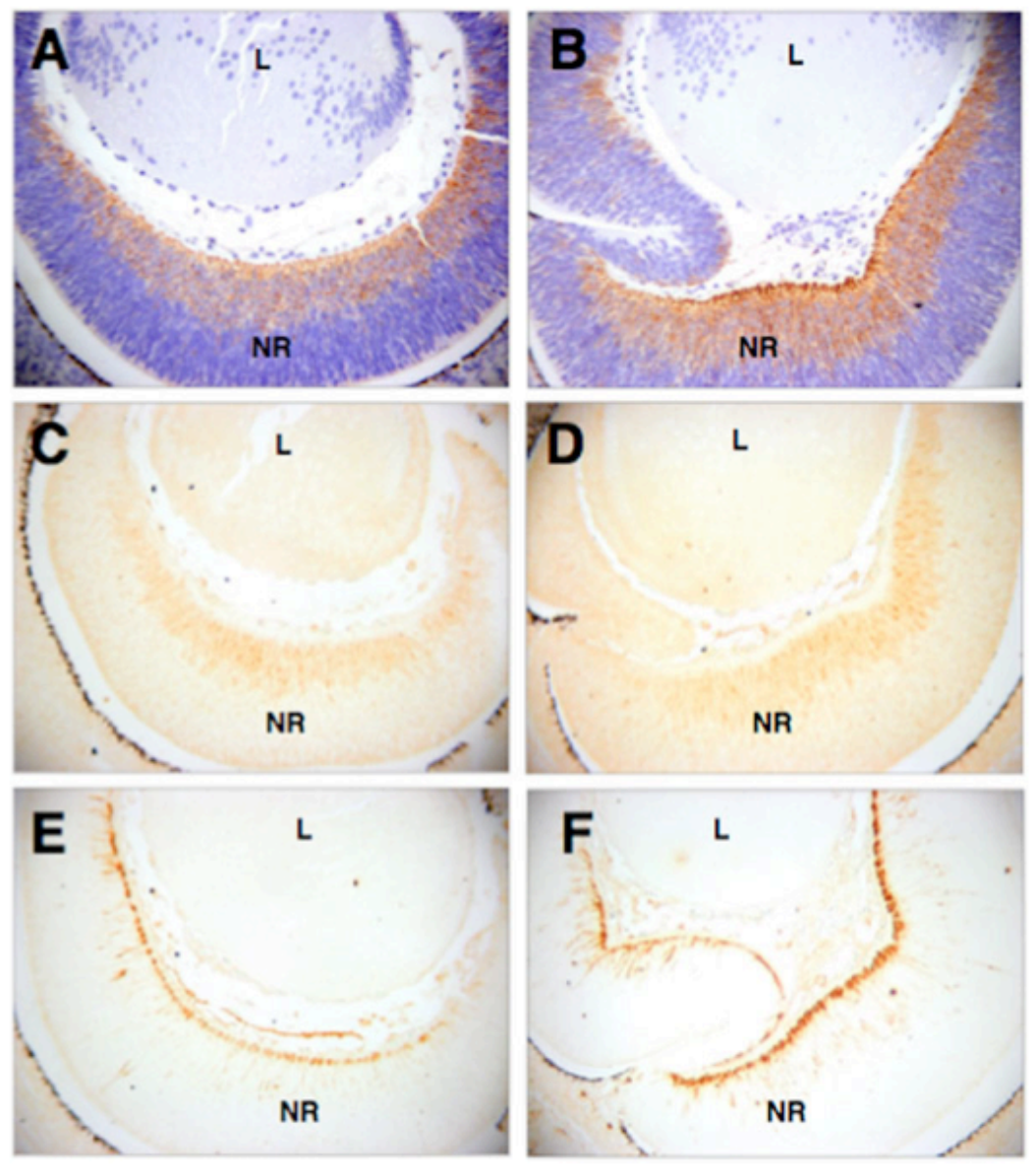

11. ábra: A progenitor elöalakok sorsa nem változott a rybp ${ }^{+/-}$mutáns szemekben. 
Vad típusú $(A, C, E)$ és rybp heterozigóta $(B, D, F)$ szemekböl készült koronális szekciók. A mutáns szemek (B, D, F) kolobóma fenotípust mutatnak. (A,B) TUJ1 festés; (C,D) NeuN festés; (E,F) nesztin festés. A korai neurális sejteket (precursor) jelölö nesztin, a későbbi de már érettebb neuronokat jelölö TUJ1 (pl. GGL) és a poszt-mitotikus neuronokat jelölö NeuN markerek hasonló mitázatot mutatnak a mutáns és vad típusú neuroretinában. L; lens, NR; neu-roretina, Nagyítás: (×460)

Ezek a markerek: Tuj1 (a korai neurális sejteket jellemzi; 11A, 11B ábrák), NeuN (postmitotikus, kései neuronokra jellemző, 11C, 11D ábrák) és nestin (neurális progenitor sejtekre jellemző; 11E, 11F ábrák). A neurális markerek látszólagos normális eloszlása arra enged következtetni, az rybp mutáns retinában a neurális sejt differenciáció nem érintett, és nem is az optic fissure bezáródás elmaradásának egyenes oka.

\subsection{A $r y b p^{-/-}<_{->} r y b p^{+/+}$kiméra embriók változatos szemfejlődési rendellenességeket mutatnak}

$\mathrm{Az}$ rybp $^{-/-}$egerek korai embrionális letalitása megakadályozza a gén organogenezisben, így a szem fejlödésében betöltött szerepének vizsgálatát is. Mivel lehetőség volt kiméra embriók ( $\mathrm{n}=90)$ létrehozására (anyag és módszer fejezet), ezért módunkban állt a szem hisztopatológiai analízisének elvégzése kiméra állatokon. Mint fentebb részletesen leírtuk a kiméra embriók 20\%-a mutatott fejlődési rendellenességeket, melyek túlnyomó többsége az előagyi régiókra korlátozódott. 

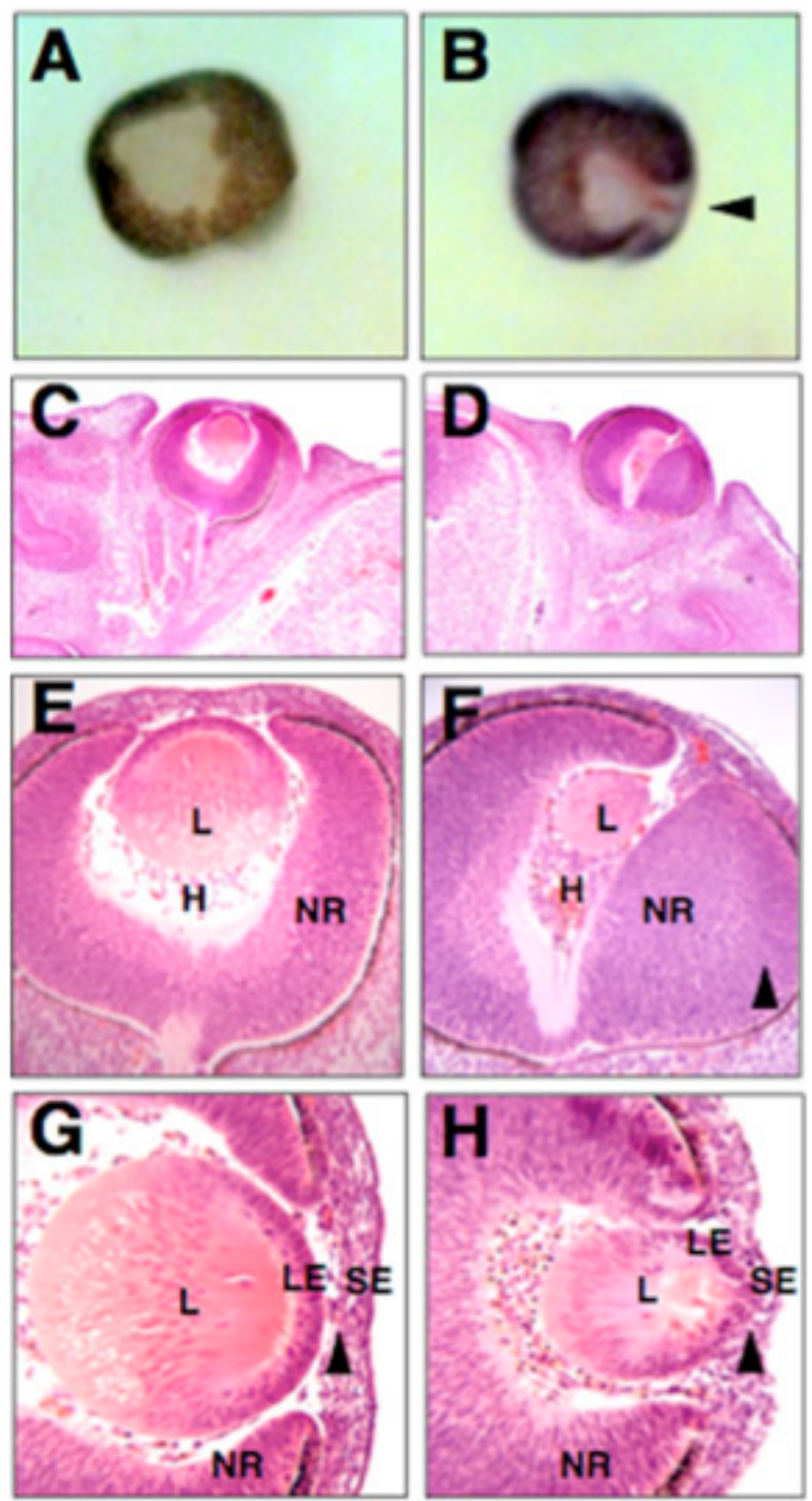

12. ábra: Változatos defektusok figyelhetök meg a rybp ${ }^{-/-}<_{->}$rybp ${ }^{+/+}$kiméra embriók szemében.

(A,B) E13.5 napos whole-mount vad típusú (A) és rybp ${ }^{-/-}<_{-}>$rybp ${ }^{+/+}$kimerikus szemek (B) általános morfológiája. A vad típusú szem szimmetrikus, míg a kiméra állatok szemében a chorioid fissure (chorioid hasadék) nyitott (kolobóma) (B; nyilfej). 
(C, F) E13.5 napos vad típusú (C, E) és kimerikus (D, F) embiók koronális szekciói. Nagyobb felbontású felvételek a “C, D" panelek megfelelő régióiról az "E-F" paneleken láthatók. A kimerikus embriókban a szemek rendellenesen rotáltak, a lencse fejlödése elmaradott és a retina asszimmetrikusan megvastagodott ( $F$; nyílfej). $(G, H)$ E13.5 napos embriónál a mutánsokban (H) hiányzik egy sejtréreg a SE és a LE között, ami a vad típusú szemekben $(G)$ jelen van. A mutánsokban a LE keverve van a SE- vel és mezenhimával (H; fekete nyilfej). H; hyaloid cavity, L; lencse, LE; lencse epitélium, NR; neuroretina, SE; surface ectoderm. Nagyítások: A-B (×120); C-D $(\times 60) ; E-F(160 \times) ; G-H(\times 400)$

Ezen embriók hisztopatológiai analízise kimutatta, hogy 50\%-uk szemfejlődési rendelleneségeket is mutat, köztük renitális kolobómát (12A, B ábrák) és különböző defektusokat a szemlencse formálásában (12D ábra összehasonlítása 5C-vel; 5F ábra összehasonlítása 12E-vel). Ezen felül egy E13.5 napos embrióban az Ep és SE közötti szeparáció imkomplett volt (12H ábra összehasonlítása 12G-vel). Ezek a megfigyelések szintén alátámasztják, hogy a normális lencse és retina kialakulása a Rybp dózisától függő fejlődési folyamat.

\subsection{Az Rybp túltermeltetése szemlencse, retina és szaruhártya fejlődési rendellenességekhez vezet}

Az Rybp overexpressziója szemlencse, retina és szaruhártya károsodást okoz: A következő lépésben egy kondícionált ektopikus overexpressziós stratégiát [16] alkalmaztunk annak érdekében, hogy tanulmányozni tudjuk a Rybp túltermelődésének hatását a szemlencsében. Első lépésben bevittünk egy indukálható EGFP fúziós fehérje gént az egér genomba ( $T g^{R O S A 26-R Y B P / E G F P /+}$ egér; 13A ábra). 
A
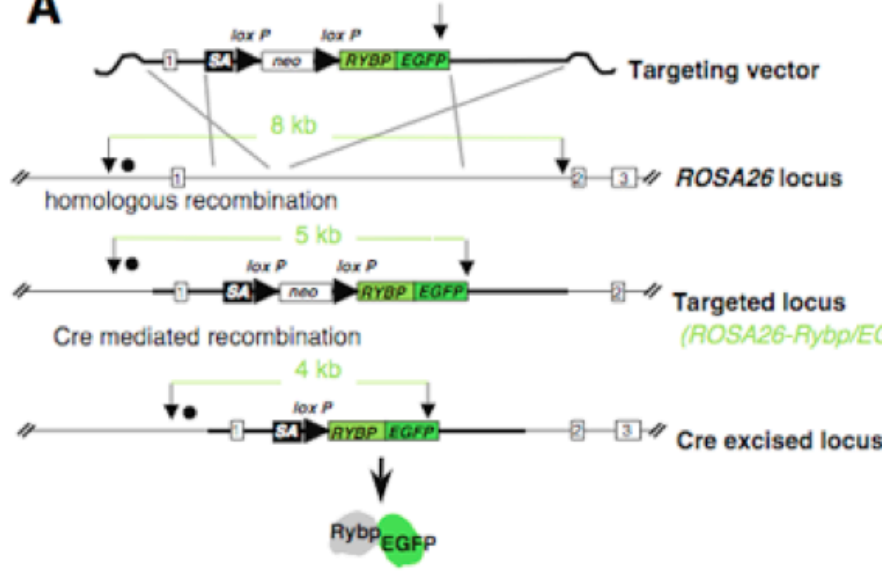

D

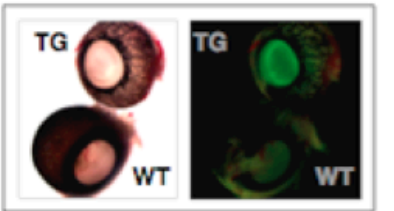

E

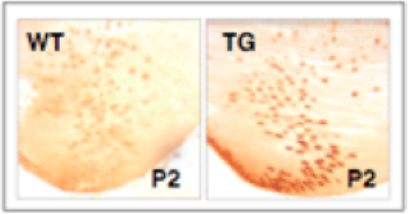

B

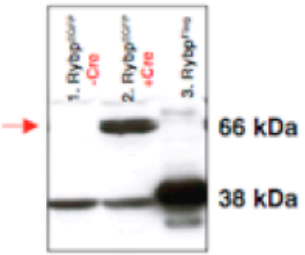

C

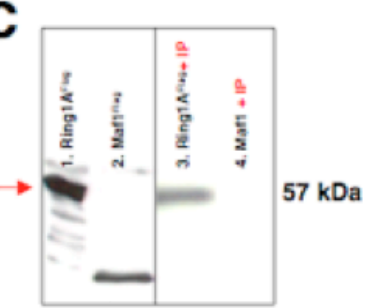

$\mathbf{F}$

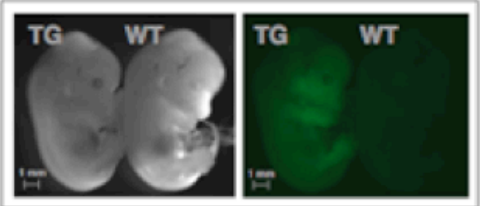

13. ábra: Szemlencse specifikus vagy áltlános módon expresszálódó RYBP/EGFP fúziós fehérje.

(A) Vázlat, amely bemutatja a Cre rekombináz-mediált kondicionált ektopikus Rybp allélek létrehozásához használt stratégiát, amelyben a ROSA26 lókuszt targetáltuk. A Southern blot-hoz használt hibridizációs próba és a használt EcoRV restrikciós enzim (nyíl) is fel van tüntetve, amelyet a homológ integránsok detektálásának kimutatására használtunk. A használt 5' próba egy $11 \mathrm{~kb}$ vad típusú és egy 3,8 kb targetált fragmentumot detektál egy többlet EcoRV felismerö hely létezése miatt a tergetált allélekben. Az exonokat a nem satírozott kockák jelölik: Cre: Cre rekombináz; EGFP enhanced green fluorescens protein; Neo: neomicin foszfotranszferáz. (B) A Cre rekombinázzal kezelt sejtek lizátumának Western blot analízise, amely a Rybp/EGFP fúziós fehérje expresszióját mutatja. I-es oszlop: ROSA26 knock -in ES sejtvonal lizátum, Cre kezelés elött (-Cre); II-es oszlop: ROSA26 knock -in ES sejtvonal lizátum, Cre kezelés után (+Cre); III-as oszlop: Rybp-Flag konstrukcióval transzfektált ES sejtekböl nyert lizátum, mint pozitív kontroll. A membránokat Rybp 
ellenanyaggal jelöltük. (c) Ektopikusan kifejezett Rybp kötödik a RinglA fehérjéhez. III oszlop transzfektált ES sejtlizátumok, amelyeket Flag ellenanyaggal blottoltunk ami azt mutatja, hogy mind a RinglA-Flag (I. oszlop) mind a MafI-Flag (II. oszlop) erösen expresszálódnak a transzfektált sejtekben; I. oszlop: RinglA-flag konstrukcióval transzfektált sejtek; II.: oszlop MafI-Flag konstrukcióval transzfektált sejtek. III-IV oszlopok: Sejtek RinglA-Flag-gel (III. oszlop) vagy MafI-Flag-gel transzfektált sejtek lizátumai, amiket aztán Rybp ellenanyaggal immunoprecipitáltunk, majd Flag ellenanyaggal blottoltunk. A III. oszlop mutatja, hogy az 57 kDa méretü RinglA-Flag fúziós fehérje a Rybp/EGFP fehérjéhez kapcsolódik. MafI nem kötödik a Rybp-hez (IV. oszlop). (D) P1 szemek, amiket a dupla transzgénekböl (ROSA26RYBP/EGFP; alphaA-crystallin/Cre egere) valamint a vad típusú egerekböl izoláltunk fluoreszcens mikroszkópos vizsgálattal. (E) Szemlencse specifikus overexpresszált RYBP/EGFP újszülött (P2) egerek szemlencséjében. GFP immunohisztokémiai festés mutatja a TG túltermelését.

Fehérjét vontunk ki a targetált $\mathrm{ES}$ sejtvonalakból $\left(\operatorname{Tg}^{\text {ROSA26-RYBP/EGFP/+ }}\right.$ sejtvonal) Cre indukció előtt és után ( $T g^{R O S A 26-R Y B P / E G F P /+; C r e}$ sejtvonal) és a várt $66 \mathrm{kD}$ molekulasúlyú Rybp/EGFP fúziós fehérjét detektáltuk (13B ábra). Ahhoz, hogy bebizonyítsuk, hogy a fúziós fehérje müködőképes, és hogy kötődik a már korábban kimutatott Ring1A fehérjéhez [4], a kivágott sejtvonalakat (ROSA26-RYBP/EGFP, Cre sejtvonalak) tranziensen transzfektáltuk Flag taggelt Ring1A fehérjével, majd a sejtlizátumot RYBP vagy GFP ellenanyaggal immunoprecipitáltuk és Flag ellenanyaggal blottoltuk. Ahogy vártuk, a RYBP/EGFP fúziós fehérje a Ring1a fehérjével in vivo detektálható (13C ábra).
A $T g^{R O S A 26-R Y B P / E G F P /+}$
egereket két
különböző ripo
riporter egér vonallal 
kereszteztük, és a fúziós fehérje expresszióját fluoreszcens mikroszkóp segítségével vizsgáltuk. Szemlencse-specifikus expresszió volt látható a ROSA26-RYBP/EGFP; alphaA crystallin/cre dupla transzgéneknél (13D ábra) és egy általános expresszió a ROSA26+RYBP/EGFP; betaActin/Cre dupla transzgéneknél (13F ábra). A $T g^{\text {ROSA26- }}$ $R Y B P / E G F P$;alphaA crystallin/cre egerek aberrált lencse morfológiáját a 14. ábra mutatja. Noha a P2 embrionális szemlencse csak nagyon finom elváltozásokat mutat a rost sejtek morfológiájában (14A-B ábrák), az idősebb egerek szemlencséjében komoly opacitás fejlődött ki, amely a szemlencse rostok tömegének összeomlásához vezetett (14C-D ábra).

$T g^{R O S A 26-R Y B P / E G F P \text {; betaActin/cre }}$ egerek szemeit vizsgáltuk embrionális korban (E16.5; E18.5), születés után (P1-P4, P7, P14 es P21) valamint felnőtt korban (2, 3 és 6 hónapos korban) (8. ábra és nem mutatott adat). Az állatok minden sejtjében expresszálódó RYBP/EGFP számos szemszövet károsodásának a kifejlődését eredményezte.

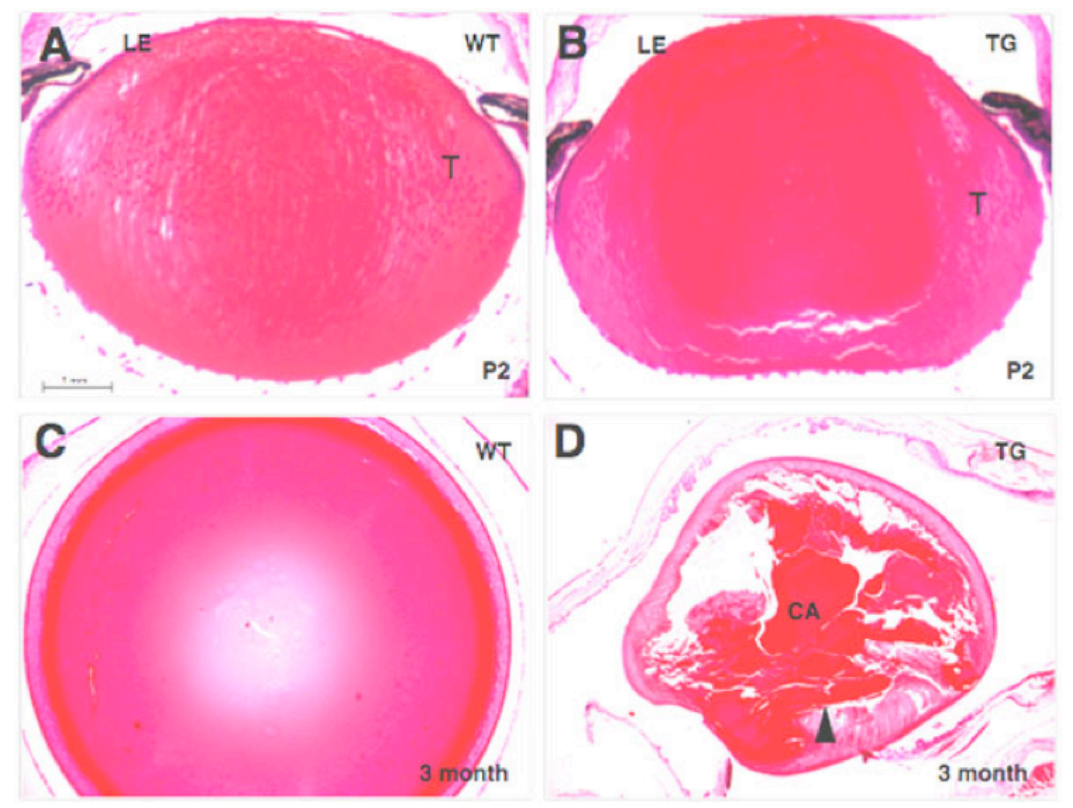

14. ábra. Rendellenes szemlencsefejlödés a szemlencse-specifikus rybp transzgenikus egérben. 
(A-D) Hisztológiai kép a vad típusú $(A, C)$ és a $\operatorname{Tg}^{\text {ROSA26-RYBP/EGFP; alphaA crystallin/cre }}(B$, D) egerek szemlencséjéröl, korai (P2) (A, B) és késői (3 hónap) (B, D) fejlődési stádiumban. A transzgenikus szemek kortikális inhomogenitást mutatnak, ami szürkehályog képzödésnek és rendellenes szemlencsefejlödésnek a jele. A felnött (3 hónap) transzgenikus egerek szeme elörehaladott szürkehályog morfológiát mutat. (D). CA; cataract/szürkehályog, L; lencse, LE; lencse epithelium, T; tranzíciós zóna, $T G$; transzgenikus, Vt; vad típus; P; postnatal. Nagyítás: $A-B(\times 160) ; C-D(\times 250)$; $E-F(\times 120)$

A leggyakoribb fenotípus a szaruhártya neovaszkularizációja (az egerek 35\%-a) (15CD ábrak összehasonlítása 8A-B) volt.
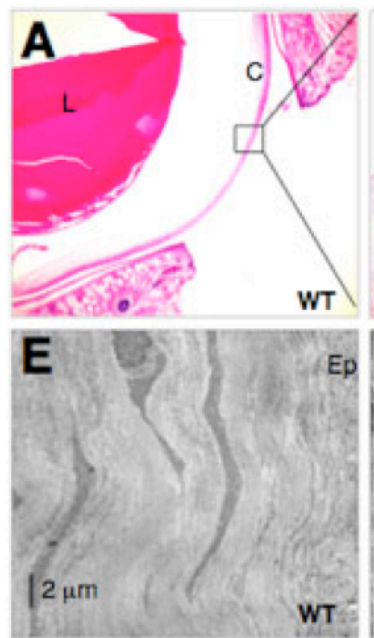

B

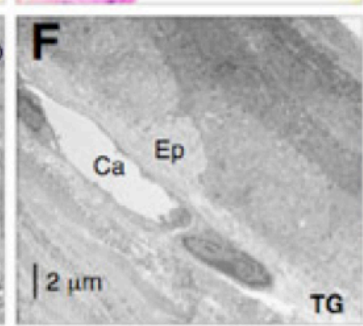

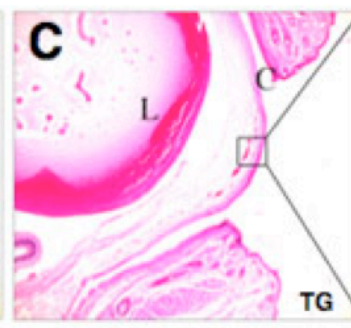

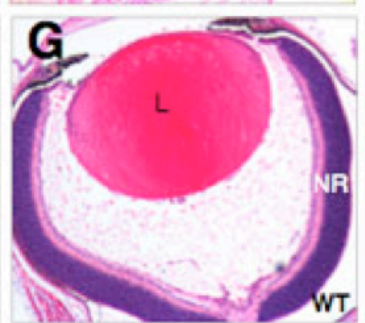

D

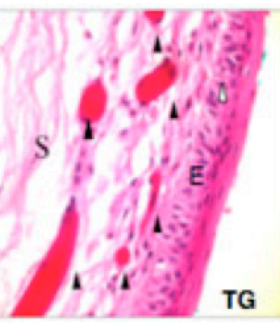

H

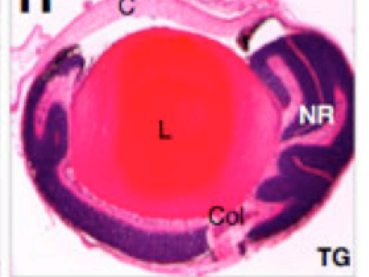

15. ábra. Rybp transzgenikus egerekben a szaruhártya neovaszkularizációja és a retina rendellenes fejlödése figyelhetö meg.

(A-F) Felnött (2 hónapos) $T^{\text {ROSA26-RYBP/EGFP; betaActin/cre }}$ egerek szaruhártyáján megfigyelhetö neovaszkularizáció. Vad típusú $(A, B)$ és transzgenikus (C, D) egerek szemének szagitális irányú metszetei, hematoxylinnal és eozinnal festve; a panel B és D a panel A és C téglalappal jelölt, kinagyitott részeit ábrázolják. A transzgenikus egér sztrómájában megjelenő erek (nyíl a panel D-ben) jelzik a szaruhártya 
neovaszkularizációját. A transzgenikus egerek epitéliuma is rendezetlen (D, üres nyill). (E-F) elektronmikroszkópiás felvétel, mely 3 hetes transzgenikus (Tg) és vad típusú (Vt) állatokban mutatja a szaruhártya sztrómát a szaruhártya epitélium mellett. Mig a Vt egér sztrómája nem tartalmaz ereket, egy kapillárist látunk a Tg egér szaruhártya epitéliuma közelében. $(G, H)$ Az újszülött $T g^{R O S A 26-R Y B P / E G F P ; b e t a A c t i n / c r e ~} e g e ́ r$ retinája rendellenes fejlödést és coloboma képzödést mutat (H) összehasonlítva a Vt kontrollal (G). C; cornea/szaruhártya , Col; coloboma, E; epithelium, Ep; corneal epithelium; L; lencse, NR; neuroretina, vt; vad típus, S; sztróma, TG; Transzgenikus. Nagyítás: $A, C(\times 200) ; B, D(\times 460) ; G-H(\times 160)$

Ezek a szerkezeti változások születés után (P7-21) láthatóak voltak, és a sztrómális rétegek vastagodásával a fenotípus fokozatosan súlyosbodott. Amikor hemizigóta egereket párosítottunk annak érdekében, hogy az RYBP/EGFP transzgénre homozigóta állatokat nyerjünk (erősebb Tg overexpresszió), a fenotípus penetrációja 80\%-ra nőtt. Ez alátámasztja, hogy a Rybp dózisa fontos a szem fejlődése folyamán is. A születés utáni első 3 hétben (P1-P21) kis véredényeket lehetett megfigyelni a szaruhátyán fénymikroszkóppal, ami 2-4 hónappal a születés után már a szaruhártya nagymértékü neovaszkularizációjához vezetett. Elektronmikroszkópikus vizsgálatok kimutatták, hogy a kapillárisok már jelen vannak a születés pillanatában is a transzgenikus szaruhártyákban (15E, F). Ezt a megfigyelést még inkább alátámasztották a CD34 ellenanyaggal végzett immunfestések. A CD34 ellenanyag az újonnan kialakult véredényeket jelöli (nem mutatott adat). A neovaszkularizáció mellett más szem fenotípusok is előfordultak. Ezek a retina részleges záródása (kolobóma), elülső szem fejlődésének defektusa (az üvegtest és az elülső csarnok hiánya) és a szemlencse elhomályosodásai (szürkehályog) voltak, amely a felnőttkor 
későbbi időszakaszaiban alakul ki $(15 \mathrm{G}, \mathrm{H})$. Összefoglalva, kifejlesztettünk transzgenikus egér modelleket, amelyekben a Rybp gén termékének fiziológiás szint feletti (patológiás) jelenléte a szemlencsében a szemlencse izomrostok differenciációját meggátolta, általános expressziója pedig a szaruhártya neovaszkularizációját okozta, valamint az elülső szem fejlődésének a meghibásodásához vezetett. Ezek a modellek azt sugallják, hogy a normális szemfejlődés érzékeny a megfelelő mennyiségü Rybp mennyiségre és hogy a nem megfelelő Rybp dózis többfajta egyéb szem rendellenességet is okoz.

\subsection{Az rybp transzgenikus lencsékben bizonyos gének expressziója megváltozott}

Az abnormális lencse rostok differenciációjának molekuláris vizsgálatára a $T g^{R O S A 26-R Y B P / E G F P \text {;alphaA crystallin/cre }}$ egerek $(15,16$. ábrák) mRNS szintű expressziós analízisét kvantitatív RT-PCR segítségével végeztük el (16. ábra; anyag és módszer fejezet).

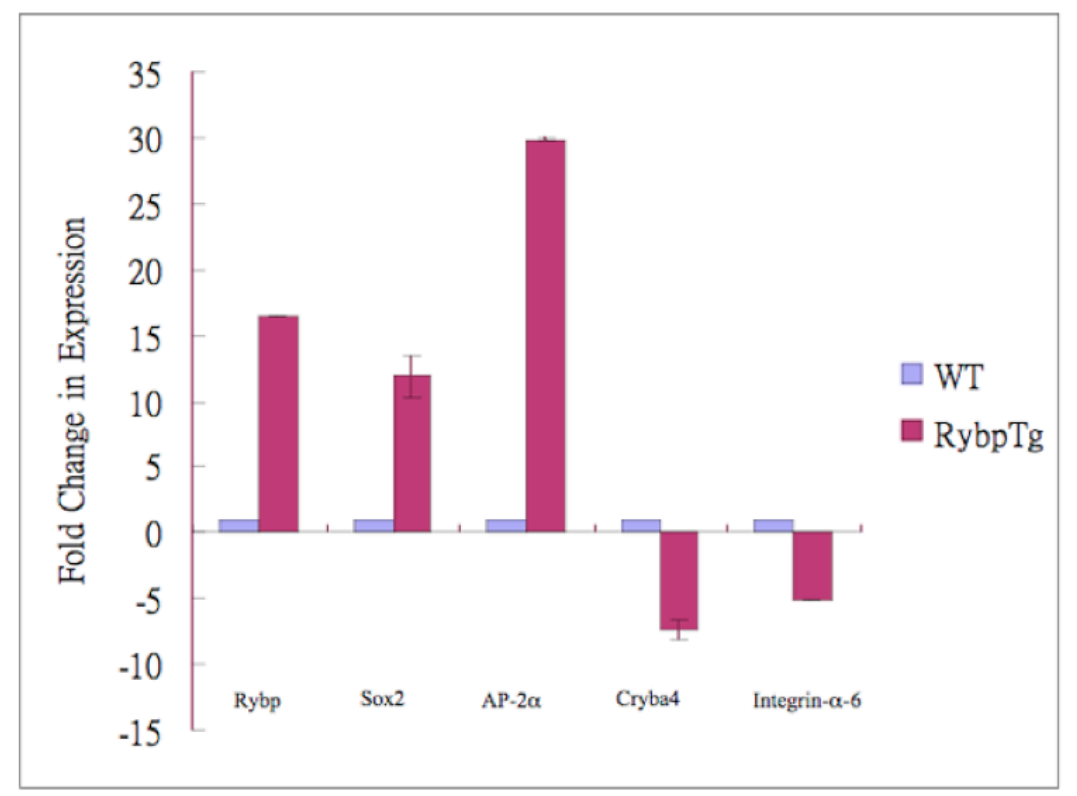

16. ábra. Rybp transzgenikus szemlencsék kvantitatív RT-PCR analízise. 


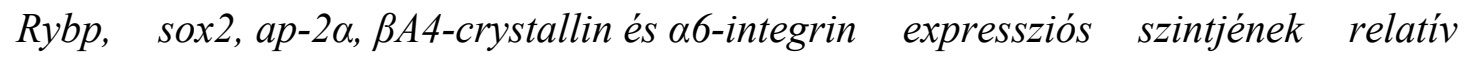
változása P1 szemlencsékben. Az expressziós szintek b2m szintjére vannak normalizálva.

A P1 kontroll $\left(r y b p^{+/+}\right)$és transzgenikus $\left(T g^{R O S A 26-R Y B P / E G F P ; \text { alphaA crystallin/cre }}\right)$ lencsék analízise kimutatta, hogy mind a Rybp mind pedig az EGFP gén transzkriptjeinek mennyisége 16x-ra nőtt a transzgenikus egerek szemlencséjében a kontrollokhoz képest. A fő lencsealkotó strukturális proteinek közül a Cryba4 7x-es redukciót mutatott a transzgenikus lencsékben, míg a többi krisztallin és filenzin mennyisége nem változott. A tesztelt sejtadhéziós molekulák közül az alpha6-integrin mRNS szint ötödére csökkent, míg a többi integrin ((alpha5- and beta1-integrins) mennyisége változatlan maradt. A tesztelt transzkripciós faktorok közül az AP-2alpha szint 30x-ra a Sox2 12x-ra emelkedett. A Pax6, Prox1, MafA, MafB and c-Maf transzkripciós faktorok mennyisége nem változott számottevően. Ezek az eredmények megerősítik, hogy a normális szemlencsefejlődés a Rybp dózistól függ.

DNS microarray tanulmányok és egyéb kondícionális mutánsokon végzett tanulmányok valószínüsíthetően további hasznos információkkal szolgálnak a jövőben arra vonatkozóan, hogy a Rybp dózis vajon melyik membrán protein, gap junction fehérje és egyéb beta/gammakrisztallin expressziójára van hatással? 


\section{AZ EREDMÉNYEK MEGVITATÁSA}

Jelen tézis keretében bemutatott kísérletek szolgáltatták az első genetikai bizonyítékot arra, hogy a Rybp gén esszenciális szerepet játszik az embriogenezisben, különös tekintettel a központi idegrendszer kialakulására. Esszenciális az organogenezisben is, hiszen a heterozigóták egy részében és a kiméra állatokban a Rybp gén müködésének felfüggesztése az előagy és szem fejlődési rendellenességeit okozza. A fenotípusban megfigyelt elváltozások összhangban állnak a Rybp embrionális fejlődés során detektált expressziós mintázatával.

Az rybp nullhomozigóta embriók a korai barázdálódást még túlélik, majd belépnek a beágyazódás stádiumába, ahol már nem képesek tovább fejlődni és elpusztulnak. A letalitás időpontja méhen belül 5.5 - 6.5 nap közé tehető (E5.5 - E6.5) amikor mind proliferációs mind apoptotikus defektusok mutatkoznak. A korai fejlődési stádium túlélése azt mutatja, hogy a Rybp szerepét ebben a korai fejlődési szakaszban vagy az anyai Rybp helyettesíti, vagy az egyéb redundáns funkciójú fehérjék, így esetleg ez a fehérje nélkülözhető ebben a korai fejlődési szakaszban. Ezt sugallja az is, hogy ES sejtekben a Rybp hiánya nem sejtletális, hiszen a homozigóta deléciós sejtek létrehozhatók, ezek a sejtek osztódásra képesek hasonlóan a parentális sejtvonalhoz és elektronmikroszkópiás szinten sem detektálhatók különbségek. Lehetséges egy bizonyos mértékü ellensúlyozás, amelyet feltehetőleg a Rybp családjába tartozó Yaf2 fehérje biztosít. A Yaf2-ről kimutatták, hogy már a blasztocisztában is kifejeződik (valamint a korai embrióban és placentában is) [10]. Azonban úgy tünik, hogy a beágyazódás ideje körül az embrionális proliferációnak/túlélésnek a zigóta-eredetű Rybp korlátozó tényezője. Ezt a szerepet támasztják alá az általunk végzett in vitro kísérletek eredményei is, amelyek azt 
mutatják, hogy az $r y b p^{-/}$blasztociszták képtelenek életképes epiblaszt/belső sejtcsomó létrehozására. Fontos megjegyezni hogy az in vitro tenyésztett homozigóta null blasztociszták szintén képtelenek voltak felismerhető trofektodermális (TE) struktúrák létre hozására, ami érdekes megfigyelés annak fényében, hogy a trofoblaszt sejtekben és azok leszármazottaiban, a chorionban és a kifejlett placentában, drámaian magas szintü az Rybp expresszió. Közismert, hogy a trofoblaszt sejtek fontos szerepet játszanak a beágyazódási folyamatban, mivel ők azok, amelyek beborítják a méh szövetet és létrehozzák az átmenetet az anyai és a magzati keringési rendszer alkotóelemei között és fontos szerepük van a terhes méhnyálkahártya (decidua, decidualizáció) kialakításában is. Csábító azt feltételezni, a Rybp hiánya befolyásolja a korai trofoblaszt biológia egyes elemeit (proliferáció, differenciáció, migráció, funkció) ahogy erre már mások is rámutattak más „knock out” egerek esetében [2931]. A hiányos trofoblaszt magyarázhatja azt, hogy miért képtelenek előidézni az $r y b p^{-/-}$embriók a teljes decidualizációt in vivo, amelyet a beágyazódás kezdeményezését követő apoptózis hiánya magyaráz. A decidualizáció meghiúsulása azonban a fejlődés leállásához vezethet, noha azt sem zárhatjuk ki, hogy ezt az epiblasztban rejlő rendellenesség okozza. További vizsgálatok magyarázatot adhatnak arra is, hogy vajon a korai hibák elsősorban extraembrionális természetűek-e, és ha igen, akkor a trofoblaszt milyen mértékben érintett. Néhány PcG protein TE sejtvonalban betöltött represszív szerepe ismert az irodalomból, ahogy az Xinaktivációban és imprintingben betöltött funkciójuk is, ami részben a TE sejt vonalhoz és leszármazottaihoz (extraembrionális szövetek) köthető [29, 32-34]. Ezek közé a fehérjék közé tartozik a Ring 1B PcG fehérje, amely bizonyítottan kötődik a Rybp-hez is illetve a Yaf2-hoz is $[4,10]$. 
Az Rybp beágyazódásban betöltött szerepén felül jelen tanulmány elsőként írja le a központi idegrendszer és szem fejlődésében betöltött szerepét is. Erre a kiméra tanulmányok és a szemipenetráns heterozigóta egerekben észlelt fenotípusok adtak elsősorban lehetőséget. A kiméra módszer lényege, hogy a korai embrionális letális fenotípusok részben áthidalhatók és vizsgálhatók, ha a defektív sejteket egy olyan kontextusba helyezzük, ahol túlélésük a környező vad típusú sejtek segítségével elősegítődik. Így gyakorlatilag egy kimerikus állatot hozunk létre, amelynek a sejtjei kétféle (vagy akár többféle) genotípusból tevődnek össze, jelen esetben a null homozigóta és vad típusúból. Ezen tanulmányok valamint az a tény, hogy a heterozigóták egy része (15-25\%) szintén defektust mutat a központi idegrendszer és a szem fejlődésében arra utalt, hogy a Rybp hatása dózis-függö. Ezt szintén alátámasztja, hogy az észlelt fenotípus a genetikai háttertől is függött: az előfordulás a 129Sv/J aránnyal nőtt míg CD1-el csökkent. Fontos megfigyelésünk még, hogy a heterozigótákban észlelt „,exencephaly” (nyitott koponya/fej) gyakran közölt fenotípus genetikailag módosított egerekben $[35,36]$, különösen homozigótákban és gyakran a „haldokló” (moribund) vagy kompromittált embriók jellegzetessége. Esetünkben azonban az a tény, hogy a központi idegrendszer és szem szelektíven azok a szervek, amik a Rybp hiányától szenvednek, vagyis a fenotípus specifikusan ezekben a szervekben mutatkozik meg, azt bizonyítja, hogy ez a hatás specifikus és specifikusan a Rybp hiányából fakad.

A kiméra tanulmányokban észlelt fenotipikus elváltozások is egy specifikusabb funkciót sejtetnek, mint pusztán szerep a sejtek proliferációjában vagy pluripotenciájuk kialakításában. A kiméra állatokban a Rybp deficiens sejtek jelenléte az elő- és középagy kaotikus túlburjánzását okozta egyéb kaotikus elváltozásokkal egyetemben (úgymint különböző fokú velöcső záródási defektusok és a neurális 
lemezek elülső részének részleges záródása). Hogy vajon mi a kiváltója a túlburjánzásnak és a velőcső záródási rendellenességnek, egyenlőre csak találgatásokra ad lehetőséget. Valószínűleg az expressziós profil analízise a mutáns vs. vad típusú embrionális cortexnek, ahol a Rybp elsődlegesen poszt-mitótikus neuronokban expresszálódik, segíthet ezen kérdés megválaszolásában. Ez a kísérlet valószínűleg a Rybp sejtciklus szabályozásban és differenciációban betöltött potenciális szerepére is fényt vethet. Ezt a hipotézist támogatja az a megfigyelésünk is, hogy a Rybp fehérje elsődlegesen poszt-mitótikus neuronokban, a szemlencse poszt-mitótikus SLF-jeiben és a retina terminálisan differenciált sejttípusaiban (GGL, INL, fotoreceptorok) van dominánsan jelen. A szemben észlelt fejlődési rendellenességek közül a szem colobomája, mely a retina hibás összezáródása ('hasadék a szemen") következtében alakul ki fejlődésbiológiailag a legjelentősebb és legtöbbet tanulmányozott. Az agyi fejlődési rendellenességeket mutató heterozigóták 32\%-a és a kimérák 50\%-a szintén mutáns volt colobomára is, de olyan egerek is hordozták a coloboma fenotípust, akik egyéb szembetűnő fenotipikus elváltozást nem mutattak. Transzkripciós faktorok egész sora (BCOR, CBP, Chx10, Cited2, c-Maf, Foxg1, Pax2, Pax6, Ptch, Six3, Ski, Vax1 and Vax2), jelátvivő molekulák (Jnk1, Jnk2 and Shh) vagy a reninsav jelátvivő útvonal tagjai között is számos kolobóma fenotípust hordozó mutációt írtak le (5 bmc). Jelen tanulmányban elsőként mutattuk ki, hogy a Rybp fehérje szerepet játszik a kolobóma kialakulásához vezető jelátviteli folyamatokban.

A kolobóma kialakulásához vezető molekuláris változások nem tisztázottak de valószínüsíthető hogy a sejtadhéziónak, a sejtek alakjának és proliferációjának valamint a programozott sejthalálnak és extracelluláris mátrixnak szerepe van a kialakulásában. A kolobóma mellett jó néhány lencsefejlődési rendellenességet is 
megfigyelhettünk a mutánsokban úgy, mint a szemlencse ventrális rotációja. Ezt az aberrációt korábban leírták az Otx2 mutáció kapcsán [37]. Az Otx2 transzkripciós faktor a retinában expresszálódik és fontos szerepe van például a fotoreceptorok hosszú távú túlélésében és fennmaradásában. A gén mutációja szintén kolobóma kialakulását okozza. A Rybp kiméra embriók szemlencséi a lencse hólyagok abnormális szeparációját is mutatták a SE-tól ami a Pax6 heterozigóta [38] és Foxe3 homozigóta [39] mutáns egerekben előforduló fenotípus. Így meglehet, hogy a szemben a Rybp és Otx2, Pax6 vagy Foxe3 gének ugyanazon jelátvivő útvonalakon keresztül fejtik ki hatásukat. Transzgenikus lencsék, amelyek túltermelik a Rybp-et abnormálisan differenciálódtak már közvetlenül a születés után (P2), ami az öregedéssel tovább romlik s végül a lencse összeomlásához vezet. Hasonló fenotípus figyelhető meg az AP-2alpha és néhány E2F tarnszkripciós faktor [38, 40] lencsespecifikus kondícionális transzgenikus mutánsainál is. Az hogy vajon a túl sok Rybp fehérje jelenléte interferál-e a SFC-ek sejtadhéziójával, migrációjával (mint az AP-2 alpha transzkripciós faktor esetében), sejtciklusával (mint az E2F transzkripciós faktorok esetében), teminális differenciációjával (mint a TGFbeta ligand esetében) vagy egy teljesen más útvonalon hat, további tanulmányokat igényel. Tény hogy a Rybp-ról korábban leírták, hogy sejtkultúrás rendszerekben az E2F transzkripciós faktorok funkcionális specifikációjában fontos szerepet játszhat [7] noha ezidáig in vivo ezt még nem tanulmányozták.

Az Rybp általános túltermeltetése hasonló defektusokat okozott a lencsében, mint a lencse-specifikusan overexpresszáló mutánsokban, emellett még a szaruhártya neovaszkularizációja is megfigyelhető volt. Olyan géneket mint VEGF, FGF2 és MMP-2 szintén a korneális neovaszkularizáció fenotípusával hoztak összefüggésbe korábbi tanulmányokban [41, 42]. Az Rybp és angiogenezis kapcsolatának vizsgálata 
további tanulmányokat igényel, amit az expressziós mintázat analízise során megfigyeltek is indokolnak, mint pl. a hyaloid erek és a szemet körülvevő erek endotéliumaiban történő magas Rybp expresszió.

Egy lehetséges elképzelés arra vonatkozólag, hogy miképp fejti ki hatását az Rybp a PcG transzkripciós reguláció vonatkozában [4] az, hogy talán mint "master regulátor” egyéb fontos fejlődési regulátor gének expresszióját szabályozza. A PcGek multimerikus komplexek formájában szabályoznak kulcsfontosságú “fejlődési” és homeobox géneket [43]. Figyelemreméltó, hogy a már a mi általunk elvégzett kisléptékủ gén expresszió analízis is kimutatta, hogy több kulcsfontosságú regulátor gén (Sox2, AP-2a) illetve a lencse fejlődésében kruciális krisztallin [17] expressziós szintje a traszgenikus, Rybp-et túltermelő lencsékben jelentősen megváltozott. Sőt, a szem fejlődésében “master-regulátor”-nak számító Pax6 lokalizációja is megváltozott a heterozigóta egerekben. Mindezek a megfigyelések azt sugallják, hogy a Rybp más egyéb, fontos fejlődésbiológiai szereppel bíró gént regulál és hogy a regulált gének megváltozott szintje az észlelt fenotípusok előidézője a Rybp mutánsokban. Annak eldöntése, hogy ez közvetlen, vagy közvetett úton történik-e, további vizsgálatokat igényel. Így annak eldöntése is, hogy vajon mindez az Rybp és a PcG represszorok kölcsönhatásai által szabályozódik-e. Érdekes, hogy szintén abnormális elülső szemfejlődés figyelhető meg a Ring1 deficiens egerekben, hasonló, mint amit mi megfigyeltünk a Rybp mutáns egerekben [44], sőt, az YY1 ${ }^{+/-}$; Ring $1^{-/-}$összetételü egerekben ez a fenotípus felerősödik. Mivel mind a Ring1, mind pedig az YY1 kölcsönhat a Rybp-vel és egyéb Class II PcG-el, lehetséges hogy ezek a proteinek funkcionálisan kölcsönhatnak annak érdekében, hogy a gerinces szem fejlődését irányítsák. 
Népszerü álláspont az, hogy nyitott velőcső rendellenességet mutató fenotípusért a neuroepiteliális sejtproliferáció/differenciáció egyensúlyának a megbomlása a felelős. Egyéb velőcső záródásban szerepet játszó folyamatok, úgymint a koponyacsont mezenchymális sejtjeinek a proliferációja és expanziója, citoszkeletális újrarendeződés, velőcső (neurális crest) sejtek vándorlása, neuroepiteliális sejthalál $[35,36]$ szintén felelőssé tehetők. Noha a NTD-ek szabályozásában már számos transzkripció regulátor fehérje szerepét már leírták, a PcG proteinek szerepe tisztázatlan, kivéve a YY1 (ying yang 1) DNS kötő PcG komplex tagot [45]. Egy másik tanulmány kimutatta, hogy a valporsav, ami egyben potenciális teratogén is, és egérben, emberben egyaránt NTD-t okoz, egyúttal PcG expressziós szint változást is okoz, legalábbis axio-szkeletális kontextusban [46]. A Rybp mutáns egerekben észlelt NTD-ok egyben arra is utalnak, hogy az Rybp szerepet játszhat a neurális szabályozásban fontos PcG protein-mediált csendesítésben (silencing).

Fontos megemlíteni, hogy a Rybp heterozigóta egerekben észlelt fenotípusok (NTD) a pro-apoptotikus génekre (caspase 9, caspase 3, apaf1; [47]) jellemző fenotípusok is egyben. Ezen nullmutáns embriók NTD-je apoptózis és sejthalál, valamint az éretlen előagyi neuronok és prekurzor sejtek megzavart szabályozása miatt alakulnak ki [47]. A jövőben az rybp null embiók központi idegrendszere (mind a heterozigótáké, mind pedig a kiméráké) és a pro-apoptotikus kaszkád tagok fenotípusának hasonlósága további vizsgálatokat igényel, hiszen tudjuk hogy (i) a Rybp fehérje kölcsönhat az apoptotikus gének egy részével (death receptor pathway tagokkal; [20]) és (ii) az Rybp deficiens egér embriók hiányos apoptotikus választ mutatnak a beágyazódás során. 
Végül meg kell említsük, hogy néhány egyéb gén szintén hasonló fenotípust mutat az általunk leírt Rybp mutáns fenotípusokkal, nevezetesen a homozigóta embrionális letális és a heterozigóta enkefalikus fenotípusokkal, így pl. a YY1 transzkripciós faktor [45], a kromatin re-modellező Brg1 [48] és Srg3 [49]. Érdekes sajátsága mindezen géneknek az, hogy képesek downstream gének egész sorát szabályozni, ami talán közös vonás a génmodifikált egerek komplex fenotípusaiban. A tézisben ismertetett $r y b p$ mutáció és fenotípusának leírása, jellemzése lehetővé teszi a Rybp fehérje potenciális szabályozási útvonalakon való elhelyezését. Az rybp mutánsok szintén hasznos eszközei lehetnek az Rybp pontos molekuláris szerepeinek tisztázásához, és ahhoz, hogy elhelyezzük a gént a transzkripciós reguláció, apoptózis vagy még fel nem térképezett egyéb molekuláris útvonalak egyikén. A jövőben kondícionális mutánsok generálásával, amelynek középpontjában a központi idegrendszer fejlődésében fontos folyamatok állnak, lehetővé válhat az Rybp molekuláris funkcióinak pontosabb megismerése és fejlődésben illetve betegségekben, öregedésben való szerepének felderítése. 


\section{AZ EREDMÉNYEK ÖSSZEFOGLALÁSA}

Kísérleteink során a $r y b p$ gén és génterméke, a Rybp fehérje biológiai funkcióit vizsgáltuk transzgenikus módszerek alkalmazásával, egérben. A rybp gén funkcióit mind génkiütéses mind pedig túltermeltetéses rendszerekben analizáltuk. A funkcióvesztéses homozigóta mutánsokat homológ rekombinációval hoztuk létre heterozigóta mutánsokon keresztül. A funkcióvesztéses mutánsban a Rybp gén termekének, ami egy 227 aminosavas fehérje, csak az első 53 aminosava íródott át, amely a funkciókért felelős domének hiányát jelentette, és ezért olyan utód egereket hoztunk létre, melyek a Rybp fehérje termelésére nem voltak alkalmasak, tehát lehetőségünk nyílt a gén hiányában fellépő fenotípusok részletes elemzésére. A túltermeltetéses mutánsokat is egy speciális homológ rekombinációt igénylö gén célba-juttatásos, state-of-the-art módszerrel hoztuk létre. Így elértük, hogy a bevitt transzgén kontrollált módon, csak egy, illetve két kópiában expresszálódjon. Ennek jelentősége abban rejlik, hogy kiküszöbölődik a „pozíció effektus variegáció” hiszen minden egyes targetált sejtvonal ugyanazon homológ módon, a Rosa26 lokuszban targetált. Így kísérleteinkben olyan párhuzamos, egymástól független sejtvonalakat tudtunk létre hozni, amelyekben a Rybp transzgén expressziója nem függött az integráció helyétől. A két komplementer módszer alkalmazásával (funkcióvesztéses és funkciónyeréses genetikai mutációk) egy speciális, érzékenyített rendszertben vizsgálhattuk a RYBP élettani szerepét térben és időben. Kísérleti rendszerünk hatékonyságát bizonyítja, hogy a gén-dózis-hatást is vizsgálni tudtuk. Ennek eredményeképp sikerült kimutatnunk hogy:

(1) A Rybp gén homozigóta állapotban letális fenotípust eredményez, tehát a gén létfontosságú. 
(2) Az rybp gén heterozigóta állapotban szemi-penetránsan letális fenotípust eredményez.

(3) Az Rybp fehérje túltermeltetése szemlencse-specifikus módon a szem fejlődési rendellenességeit okozza (coloboma, a szaruhártya fokozott vaszkularizációja és katarakta). Kimutattuk, hogy Rybp szükséges a normál retina, a szemlencse és valószínűleg az elülső szemszegment fejlődéshez.

(4) Az rybp mutáció homozigóta állapotban peri-implantációs letalitáshoz vezet, melynek oka mind embrionális, mind pedig extraembrionális rendellenességekben is megnyilvánult.

(5) A heterozigóta embriók egy részének letalitását a velőcső fejlődésének rendellenessége okozta.

(6) Az Rybp protein immunfestéssel törtenő lokalizációja, az embrionális fejlődés különböző stádiumaiban ezen megfigyeléseket szintén alátámasztotta: az Rybp protein az embriogenezis során erős jelenlétet mutatott az embrió differenciálódó sejtpopulációiban, az idegrendszer differenciált sejttípusaiban és az extraembrionális trofoblaszt óriás sejtrétegben (trofoblast giant cell; TGC).

(7) A Rybp géntermék hiánya más gének által, így például a rokon Yaf2 által nem kompenzálható, tehát a rybp és yaf2 géncsaládtagok funkciója nem tekinthető redundánsnak.

Ezen megfigyelések valószínűsítik a rybp gén szerepét a differenciáció folyamatában, különös tekintettel a központi idegrendszer kialakulására, és a sejthalál folyamatában (apoptózis). Feltételezhető továbbá, hogy a RYBP/DEDAF emberi megfelelőjének elvesztése is súlyos következményekkel, beágyazódási problémákkal (spontán vetélés), velőcső záródási defektusokkal (nyitott velőcső kialakulása) vagy apoptózissal jár. 


\section{SUMMARY}

Present work summarizes findings on the in vivo function of the mouse rybp/Rybp (ing1 and $\underline{Y} Y 1-\underline{B}$ inding Protein; also known as DEDAF, YEAF1; UniGene Mm.321633; MGI:1929059) gene/protein. Several in vitro functions (transcriptional regulator, mediator of apoptosis) have been implied from Rybp's protein interaction profile that includes DNA binding proteins (YY1), polycomb group proteins (Ring1 A, Ring1B, M33 and mPC2), and members of the pro-apoptotic caspase pathways but the precise cellular and in vivo role of Rybp currently was not well understood.

This thesis describes complementary strategies of (i) targeted mutagenesis and (ii) conditional ectopic transgenic alleles to achieve loss- and gain-of-function, respectively in order to reveal in vivo functions of rybp in the developing mouse. As a result of these studies, exciting phenotypes have emerged in these models, and present ongoing and future efforts to pursue them further. Firstly, the expression pattern of Rybp during mouse development was analysed and mice bearing a null mutation by gene targeting in embryonic stem cells was generated. Rybp was broadly expressed during embryogenesis, being particularly abundant in extraembryonic tissues including trophoblast giant cells. Consistent with this, $r y b p$ homozygous null animals exhibited embryonic lethality at peri-implantation stages - suggesting that Rybp was essential for survival of the embryo, for the establishment of functional extraembryonic structures, and for the execution of full decidualization.

This thesis also describes that through the use of a chimeric approach, the embryonic lethal phenotype was circumvented and a role for Rybp in neural 
development was uncovered. Specifically, the presence of Rybp-deficient cells in the developing central nervous system resulted in forebrain overgrowth and in localized regions of disrupted neural tube closure. Functions for Rybp in the brain were further supported by the finding of exencephaly in about $15 \%$ of $r y b p$ heterozygous mutant embryos, and by Rybp's distinct neural expression pattern. Together these data supported critical roles for Rybp at multiple stages of mouse embryogenesis and differentiation. Furthermore, however there is a possible overlap between Rybp and Yaf2 expression, obviously was not sufficient to prevent aberrant neurulation/neurogenesis and eye development resulting from reduced Rybp levels in our affected heterozygous and chimeric animals.

With a second, complementary approach, a conditional ectopic allele for Cremediated misexpression of Rybp was generated. To do this the non-essential and ubiquitous ROSA26 locus was targeted with a floxed neo cassette followed by a functional RYBP-EGFP fusion cDNA. In this mice a silent mutation was introduced where the Rosa26 locus was targeted homologous manner in ES cells. The mutation was introduced to the mouse germ line and the silent mutation could be induced by crossing these mice with cre reporter lines. Applying this strategy two different mice were generated: one expressing Rybp ubiquitously and the other expressing it tissue specific manner (under the control of AlphaA-Crystallyn promoter) in the mouse lenses. The strategy was also designed that after induction all mice expressed Rybp in a fusion with enhanced green fluorescent protein (EGFP) allowing easy monitoring of the expression pattern. These studies established rybp as a novel gene that has been associated with coloboma, a developmental disease of the eye.

These findings are likely to place Rybp in processes of differentiation, 
especially CNS and eye development, apoptosis and have implications for the understanding of neural tube defects, and neurodegenerative diseases. The cells and mice we have generated may allow us to assess the potential relationships between Rybp and these proteins and to place Rybp within known genetic networks. These tools also will provide opportunities for the elucidation of the precise molecular roles of Rybp as they relate to transcriptional regulation, apoptosis, and/or yet-to-beidentified cellular processes. In the future, the generation of conditional or tissuespecific knockout mice, with the CNS being an attractive focus, will allow us to understand more about Rybp's biological roles during development and in the context of aging and disease. 


\section{IRODALOMJEGYZÉK}

1. Lefstin JA, Yamamoto KR: Allosteric effects of DNA on transcriptional regulators. Nature 1998, 392(6679):885-888.

2. McKenna NJ, O'Malley BW: Combinatorial control of gene expression by nuclear receptors and coregulators. Cell 2002, 108(4):465-474.

3. Ogata K, Sato K, Tahirov $\mathrm{TH}$ : Eukaryotic transcriptional regulatory complexes: cooperativity from near and afar. Current opinion in structural biology 2003, 13(1):40-48.

4. Garcia E, Marcos-Gutierrez C, del Mar Lorente M, Moreno JC, Vidal M: RYBP, a new repressor protein that interacts with components of the mammalian Polycomb complex, and with the transcription factor YY1. The EMBO journal 1999, 18(12):3404-3418.

5. Neira JL, Roman-Trufero M, Contreras LM, Prieto J, Singh G, Barrera FN, Renart ML, Vidal M: The transcriptional repressor RYBP is a natively unfolded protein which folds upon binding to DNA. Biochemistry 2009, 48(6): 1348-1360.

6. Sawa C, Yoshikawa T, Matsuda-Suzuki F, Delehouzee S, Goto M, Watanabe $\mathrm{H}$, Sawada J, Kataoka K, Handa $\mathrm{H}$ : YEAF1/RYBP and YAF-2 are functionally distinct members of a cofactor family for the YY1 and E4TF1/hGABP transcription factors. The Journal of biological chemistry 2002, 277(25):22484-22490.

7. Schlisio S, Halperin T, Vidal M, Nevins JR: Interaction of YY1 with E2Fs, mediated by RYBP, provides a mechanism for specificity of E2F function. The EMBO journal 2002, 21(21):5775-5786.

8. Ogawa H, Ishiguro K, Gaubatz S, Livingston DM, Nakatani Y: A complex with chromatin modifiers that occupies E2F- and Myc-responsive genes in G0 cells. Science (New York, NY 2002, 296(5570):1132-1136.

9. Kalenik JL, Chen D, Bradley ME, Chen SJ, Lee TC: Yeast two-hybrid cloning of a novel zinc finger protein that interacts with the multifunctional transcription factor YY1. Nucleic acids research 1997, 25(4):843-849.

10. Kaneko T, Miyagishima H, Hasegawa T, Mizutani-Koseki Y, Isono K, Koseki $\mathrm{H}$ : The mouse YAF2 gene generates two distinct transcripts and is expressed in pre-and postimplantation embryos. Gene 2003, 315:183-192.

11. Madge B, Geisen C, Moroy T, Schwab M: Yaf2 inhibits Myc biological function. Cancer letters 2003, 193(2):171-176.

12. Holdeman R, Nehrt S, Strome S: MES-2, a maternal protein essential for viability of the germline in Caenorhabditis elegans, is homologous to a Drosophila Polycomb group protein. Development (Cambridge, England) 1998, 125(13):2457-2467.

13. Agherbi H, Gaussmann-Wenger A, Verthuy C, Chasson L, Serrano M, Djabali $\mathrm{M}$ : Polycomb mediated epigenetic silencing and replication timing at the INK4a/ARF locus during senescence. PloS one 2009, 4(5):e5622.

14. Surface LE, Thornton SR, Boyer LA: Polycomb group proteins set the stage for early lineage commitment. Cell stem cell, 7(3):288-298. 
15. Soriano P: Generalized lacZ expression with the ROSA26 Cre reporter strain. Nature genetics 1999, 21(1):70-71.

16. Srinivas S, Watanabe T, Lin CS, William CM, Tanabe Y, Jessell TM, Costantini F: Cre reporter strains produced by targeted insertion of EYFP and ECFP into the ROSA26 locus. BMC developmental biology 2001, 1:4.

17. Nagy A, Rossant J, Nagy R, Abramow-Newerly W, Roder JC: Derivation of completely cell culture-derived mice from early-passage embryonic stem cells. Proceedings of the National Academy of Sciences of the United States of America 1993, 90(18):8424-8428.

18. Sauer B, Henderson N: Targeted insertion of exogenous DNA into the eukaryotic genome by the Cre recombinase. The New biologist 1990, 2(5):441-449.

19. Trimarchi JM, Fairchild B, Wen J, Lees JA: The E2F6 transcription factor is a component of the mammalian Bmi1-containing polycomb complex. Proceedings of the National Academy of Sciences of the United States of America 2001, 98(4):1519-1524.

20. Zheng L, Schickling O, Peter ME, Lenardo MJ: The death effector domainassociated factor plays distinct regulatory roles in the nucleus and cytoplasm. The Journal of biological chemistry 2001, 276(34):31945-31952.

21. Tam PP, Rossant J: Mouse embryonic chimeras: tools for studying mammalian development. Development (Cambridge, England) 2003, 130(25):6155-6163.

22. Hatten ME: Central nervous system neuronal migration. Annual review of neuroscience 1999, 22:511-539.

23. Pirity MK, Locker J, Schreiber-Agus N: Rybp/DEDAF is required for early postimplantation and for central nervous system development. Molecular and cellular biology 2005, 25(16):7193-7202.

24. Torres M, Gomez-Pardo E, Gruss P: Pax2 contributes to inner ear patterning and optic nerve trajectory. Development (Cambridge, England) 1996, 122(11):3381-3391.

25. Grindley JC, Davidson DR, Hill RE: The role of Pax-6 in eye and nasal development. Development (Cambridge, England) 1995, 121(5):1433-1442.

26. Sanyanusin P, McNoe LA, Sullivan MJ, Weaver RG, Eccles MR: Mutation of PAX2 in two siblings with renal-coloboma syndrome. Human molecular genetics 1995, 4(11):2183-2184.

27. Schwarz M, Cecconi F, Bernier G, Andrejewski N, Kammandel B, Wagner M, Gruss P: Spatial specification of mammalian eye territories by reciprocal transcriptional repression of Pax2 and Pax6. Development (Cambridge, England) 2000, 127(20):4325-4334.

28. Livesey FJ, Young TL, Cepko CL: An analysis of the gene expression program of mammalian neural progenitor cells. Proceedings of the National Academy of Sciences of the United States of America 2004, 101(5):1374-1379.

29. de Napoles M, Mermoud JE, Wakao R, Tang YA, Endoh M, Appanah R, Nesterova TB, Silva J, Otte AP, Vidal $M$ et al: Polycomb group proteins Ring1A/B link ubiquitylation of histone $\mathrm{H} 2 \mathrm{~A}$ to heritable gene silencing and $X$ inactivation. Developmental cell 2004, 7(5):663-676.

30. Rossant J, Cross JC: Placental development: lessons from mouse mutants. Nature reviews 2001, 2(7):538-548. 
31. Cross JC: Genetic insights into trophoblast differentiation and placental morphogenesis. Seminars in cell \& developmental biology 2000, 11(2):105113.

32. Fang J, Chen T, Chadwick B, Li E, Zhang Y: Ring1b-mediated H2A ubiquitination associates with inactive $X$ chromosomes and is involved in initiation of $\mathbf{X}$ inactivation. The Journal of biological chemistry 2004, 279(51):52812-52815.

33. Mak W, Baxter J, Silva J, Newall AE, Otte AP, Brockdorff N: Mitotically stable association of polycomb group proteins eed and enx1 with the inactive $\mathbf{x}$ chromosome in trophoblast stem cells. Curr Biol 2002, 12(12):1016-1020.

34. Wang J, Mager J, Chen Y, Schneider E, Cross JC, Nagy A, Magnuson T: Imprinted $\mathrm{X}$ inactivation maintained by a mouse Polycomb group gene. Nature genetics 2001, 28(4):371-375.

35. Copp AJ, Greene ND, Murdoch JN: The genetic basis of mammalian neurulation. Nature reviews 2003, 4(10):784-793.

36. Juriloff DM, Harris MJ: Mouse models for neural tube closure defects. Human molecular genetics 2000, 9(6):993-1000.

37. Martinez-Morales JR, Signore M, Acampora D, Simeone A, Bovolenta P: Otx genes are required for tissue specification in the developing eye. Development (Cambridge, England) 2001, 128(11):2019-2030.

38. Baulmann DC, Ohlmann A, Flugel-Koch C, Goswami S, Cvekl A, Tamm ER: Pax6 heterozygous eyes show defects in chamber angle differentiation that are associated with a wide spectrum of other anterior eye segment abnormalities. Mechanisms of development 2002, 118(1-2):3-17.

39. Medina-Martinez O, Brownell I, Amaya-Manzanares F, Hu Q, Behringer RR, Jamrich M: Severe defects in proliferation and differentiation of lens cells in Foxe3 null mice. Molecular and cellular biology 2005, 25(20):8854-8863.

40. West-Mays JA, Zhang J, Nottoli T, Hagopian-Donaldson S, Libby D, Strissel $\mathrm{KJ}$, Williams T: AP-2alpha transcription factor is required for early morphogenesis of the lens vesicle. Developmental biology 1999, 206(1):4662.

41. Asahara T, Takahashi T, Masuda H, Kalka C, Chen D, Iwaguro H, Inai Y, Silver M, Isner JM: VEGF contributes to postnatal neovascularization by mobilizing bone marrow-derived endothelial progenitor cells. The EMBO journal 1999, 18(14):3964-3972.

42. Kato $\mathrm{T}$, Kure $\mathrm{T}$, Chang $\mathrm{JH}$, Gabison EE, Itoh $\mathrm{T}$, Itohara $\mathrm{S}$, Azar DT: Diminished corneal angiogenesis in gelatinase A-deficient mice. FEBS letters 2001, 508(2):187-190.

43. Pirrotta V, van Lohuizen M: Differentiation and gene regulation. Genomic programs and differentiation: editorial overview. Current opinion in genetics \& development 2006, 16(5):443-446.

44. Lorente M, Perez C, Sanchez C, Donohoe M, Shi Y, Vidal M: Homeotic transformations of the axial skeleton of YY1 mutant mice and genetic interaction with the Polycomb group gene Ring1/Ring1A. Mechanisms of development 2006, 123(4):312-320.

45. Donohoe ME, Zhang X, McGinnis L, Biggers J, Li E, Shi Y: Targeted disruption of mouse Yin Yang 1 transcription factor results in periimplantation lethality. Molecular and cellular biology 1999, 19(10):72377244. 
46. Okada A, Aoki Y, Kushima K, Kurihara H, Bialer M, Fujiwara M: Polycomb homologs are involved in teratogenicity of valproic acid in mice. Birth defects research 2004, 70(11):870-879.

47. Lossi L, Merighi A: In vivo cellular and molecular mechanisms of neuronal apoptosis in the mammalian CNS. Progress in neurobiology 2003, 69(5):287-312.

48. Bultman S, Gebuhr T, Yee D, La Mantia C, Nicholson J, Gilliam A, Randazzo F, Metzger D, Chambon P, Crabtree $\mathrm{G}$ et al: A Brg1 null mutation in the mouse reveals functional differences among mammalian SWI/SNF complexes. Molecular cell 2000, 6(6):1287-1295.

49. Kim JK, Huh SO, Choi H, Lee KS, Shin D, Lee C, Nam JS, Kim H, Chung H, Lee HW et al: Srg3, a mouse homolog of yeast SWI3, is essential for early embryogenesis and involved in brain development. Molecular and cellular biology 2001, 21(22):7787-7795. 


\section{KÖSZÖNETNYILVÁNÍTÁS}

Doktori dolgozatom befejezésekor hálásan mondok köszönetet mindazoknak, akik segítettek, bátorítottak, bíztak bennem és megteremtették a feltételeket ahhoz, hogy elkészülhessen ez a tézis.

Örökké adósa maradok témavezetőmnek, Dr. Gácser Attilának, aki nagy odaadással segítette munkámat és folyamatosan bátorított.

Köszönöm a Dr. Nicole Scheiber-Agus vezette laboratórium minden volt tagjának szakmai megbeszélésekben nyújtott segítőkészségüket és vitaindító ötleteiket, amelyek mind hozzájárultak ahhoz, hogy ez a dolgozat elkészülhessen.

Elsőként szeretnék külön köszönetet mondani Dr. Joseph Lockernek, akiben nemcsak egy kiváló patológust volt szerencsém megismerni, de egyben a "mesteremnek" is tekintek. Szerencsésnek érzem magam, hogy tanulhattam tőle, nemcsak hisztopatológiát hanem életszemléletet is és hogy utamat végig, a new yorki tartózkodásom alatt sőt mind a mai napig egyengeti.

Köszönöm Dr. Radma Mahmod-nak, az Albert Einstein College of Medicine Histopatologia labor vezetőjének a végzett immunohisztokémiai kísérleteim során nyújtott készséges segítségét és hihetetlen szakmai hozzáértését.

Külön szeretnék köszönetet mondani Dr. Nagy Andrásnak akinek a laborjában a transzgénikus technológiának csaknem összes csínját-bínját elsajátítottam. Itt ismerkedtem meg az őssejtbiológia alapjaival és jutottam el egy magasabb szintre nemcsak az őssejtekkel kapcsolatos technológiák müvelésében, hanem a target vektorok tervezésében is.

Köszönöm kollegáimnak, Dr Ujhelly Olgának és Dr Nemes Csillának, a tézis elkészítésében nyújtott professzionális segítségét és szakmai véleményezését. 
Köszönöm minden new yorki barátomnak és kollégámnak, elsősorban Dr. Rachel Arrigoninak (Rakéleee!) (Rybp ubiquitinálásban és sumoylálásban betöltött szerepének felderítése), Dr. Jennifer Blancknak (az rybp genomi lókusz szkrínelésére általam használt egér Rybp cDNS klónozásáért), Dr. Lucy Firthnek (“auntie Lulu”), Dr. Dave Tylernek (“UKdemonic”), Dr. Dennis Madridnak ("Dottore”), Mr. Richard Trippettnek ("uncle Rich"), Mrs. Chantal Lackamnak ("DoubleSec") és Dr. Mary Tsikitisnek (“oh Mary-Mary”), hogy szakmai hozzáértésükkel, szeretetükkel és társaságukkal emelték a fényét a minden szempontból felejthetetlen new york-i éveknek. :)

Köszönöm a házivédésem opponenseinek, Dr. Pfeiffer Ilonának és Dr. Hamari Zsuzsannának hogy alapos bírálatukkal és konstruktív javaslataikkal hozzájárultak, hogy ez a dolgozat jobbá válhasson.

Köszönöm témavezetőmnek Dr. Gácser Attilának és kollégámnak, barátomnak Dr. Ujhelly Olgának, hogy mellettem álltak a nehezebb napokban is, bátorítottak és hittek bennem. Tumbs up, you guys ROCK!

Végezetül, köszönet Emmának... :; 